\title{
Evaluation of Click It or Ticket Model Programs
}
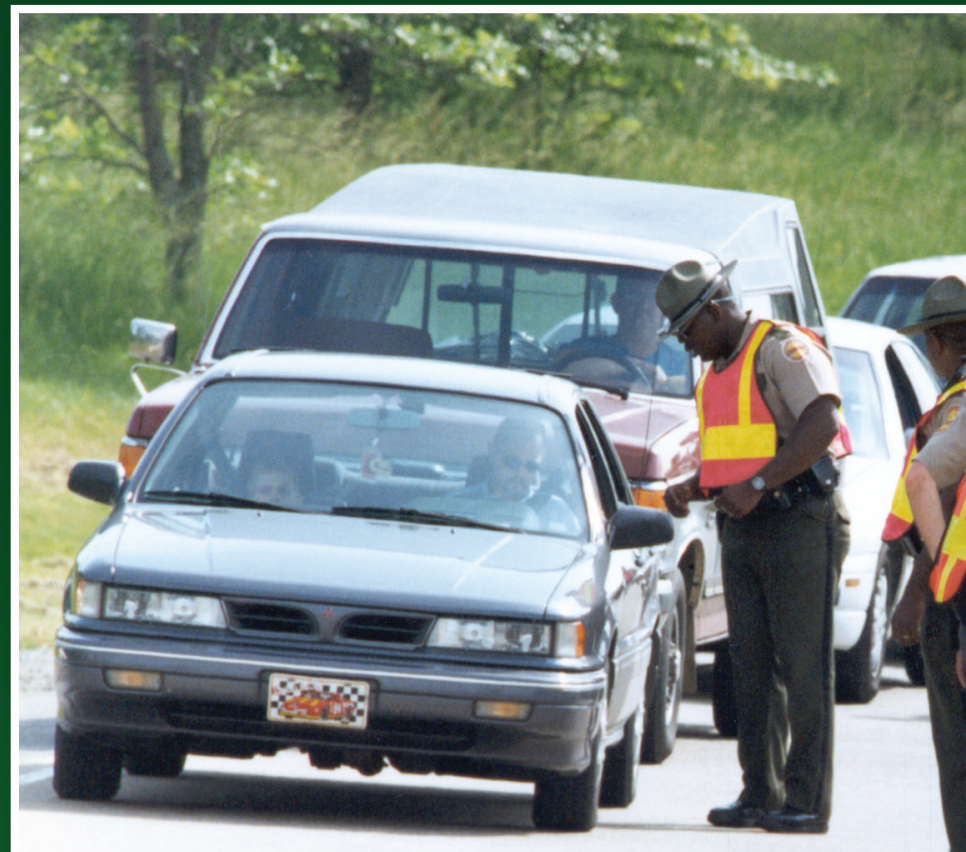

? 
Technical Report Documentation Page

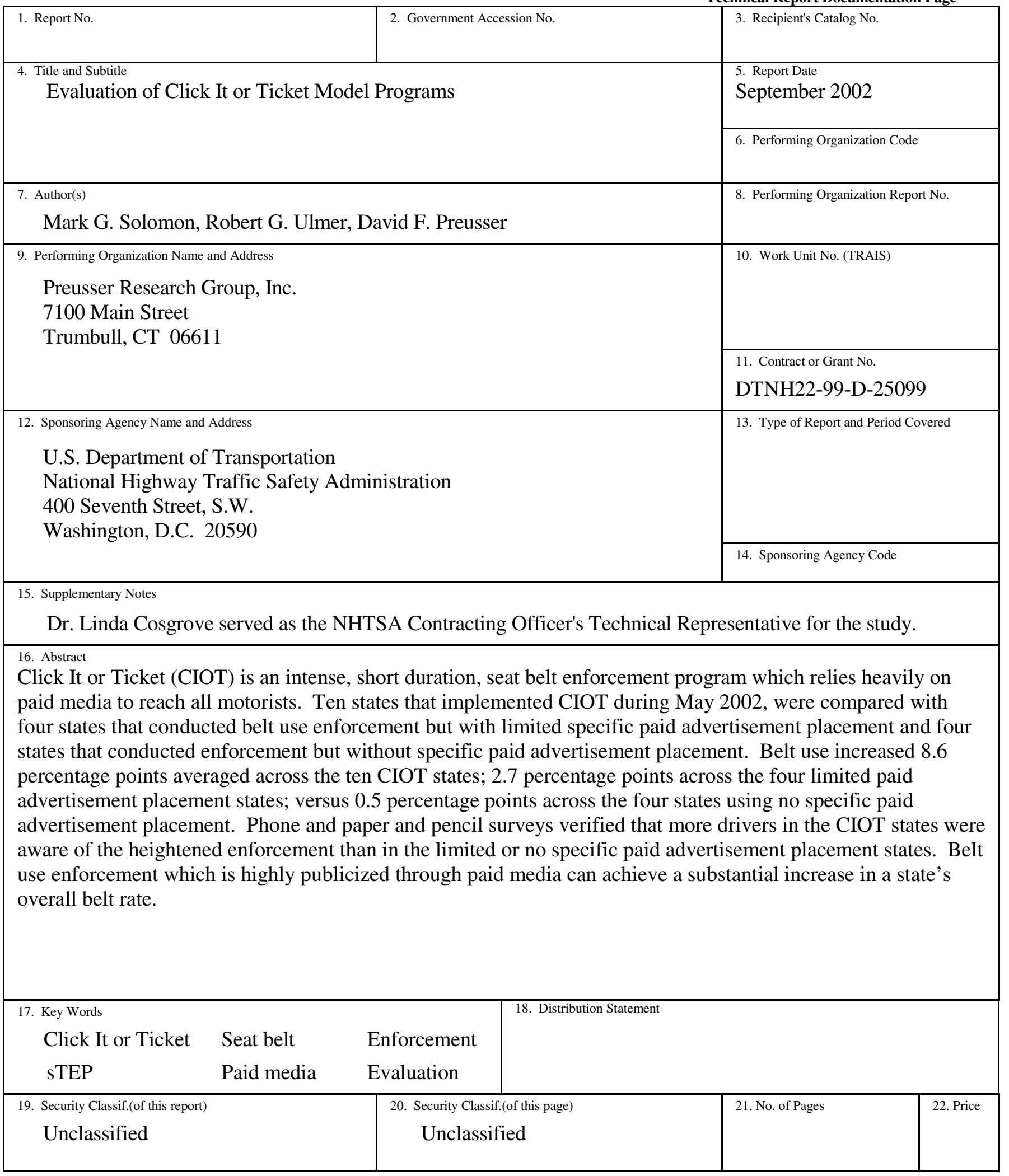


DEPARTMENT OF TRANSPORTATION

NATIONAL HIGHWAY TRAFFIC SAFETY ADMINISTRATION

TECHNICAL SUMMARY

\begin{tabular}{l|l}
\hline \hline CONTRACTOR & CONTRACT NUMBER \\
Preusser Research Group, Inc. & DTNH22-99-D-25099 \\
\hline REPORT TITLE & REPORT DATE \\
Evaluation of Click It or Ticket Model Programs & September 2002 \\
\hline
\end{tabular}

REPORT AUTHOR(S)

Mark G. Solomon, Robert G. Ulmer, David F. Preusser

\section{Background}

Selective Traffic Enforcement Programs (sTEP) for seat belt enforcement are commonplace in most states. Law enforcement liaisons working under the auspices of state highway safety agencies solicit and encourage individual police agencies to carry out increased seat belt enforcement at selected times of the year. The enforcement period is usually supported by a public information and education campaign alerting motorists that they will be ticketed for non-compliance with the seat belt law.

Federal funding for paid advertisements are leading states into committing resources towards the placement of enforcement-focused advertisements that warn motorists to buckle their seat belt or receive a ticket. Currently sTEP programs are beginning to rely on large amounts of paid advertising to quickly and substantially increase the seat belt use rate. The most notable sTEP model is Click It or Ticket (CIOT).

Click It or Ticket is an intensive and short duration traffic law enforcement program with the objective to raise seat belt use statewide. The program consists of intensive, widespread enforcement of states' seat belt laws coupled with earned and paid media that publicize the enforcement effort. Specifically, paid advertisements directly inform the motoring public about the enforcement campaign and the paid media employs "Click It or Ticket," or similar direct enforcement message, as its tag line. CIOT has positively influenced belt use in a number of states in the southeastern U.S. (Solomon 2002).

\section{Objective}

The objective of this study was to evaluate states that implemented Click It or Ticket programs. That is, states using paid advertisements to raise motorists' awareness to seat belt enforcement campaigns. Programs surrounding Memorial Day 2002, were of primary interest. The evaluation focused on observed seat belt use, motorist attitudes and knowledge and recall of program themes. Data collection occurred week-by-week, before, during and at the height of the enforcement campaign and just after the enforcement campaign ceased.

(Continued on additional pages)

"PREPARED FOR THE DEPARTMENT OF TRANSPORTATION, NATIONAL HIGHWAY TRAFFIC SAFETY ADMINISTRATION UNDER CONTRACT NO.:DTNH22-99-D25099. THE OPINIONS, FINDINGS, AND CONCLUSIONS EXPRESSED IN THIS PUBUCATION ARE THOSE OF THE AUTHORS AND NOTNECESSARILY THOSE OF THE NATIONAL HIG HWAY TRAFFIC SAFETY ADMINISTRATION."

HS Form $321 \quad$ July 1974




\section{Methods}

Observational surveys of seat belt use, knowledge/attitude surveys at Driver Licensing Offices and random resident telephone surveys were conducted in intervals to track progress.

Comparisons were made between "Full Implementation" states, "Other Implementation" states and "Comparison" states. These groups are defined below.

Full Implementation States - Statewide program employing all elements of the Click It or Ticket model: defined periods of earned media, paid media, and intensive enforcement; paid advertisement placement using "Click It or Ticket" or similar direct enforcement message; program evaluation involving before, during and after observation surveys of belt use and surveys of public perceptions of the program. Ten states: Alabama, Florida, Illinois, Indiana, Mississippi, Nevada, Texas ${ }^{1}$, Vermont, Washington and West Virginia.

Other Implementation States - Divergence from full implementation of Click It or Ticket model; some paid advertisement placement. Four states: Colorado, Michigan, Ohio and Rhode Island.

Comparison States - Divergence from full implementation of Click It or Ticket model; absence of direct paid advertisement placement. Four states: Iowa; New York; Oregon; and western Massachusetts.

\section{Activity Descriptions}

\section{Paid Media Activity}

The following Table shows the dollar amounts spent on paid media per state during the mobilization and the spending rate in terms of amount spent per resident. Generally, the amounts spent placing paid advertisement were greater in Full Implementation states compared to Other Implementation states. Comparison states spent zero. Free placement from donated spots and matching dollar agreements are not represented in this table since they were not accounted for by all states. Paid advertisement placement was not employed in the comparison states even though some amount of free airtime was received for Public Service Announcements.

\section{Enforcement Activity}

Among the 18 study states, approximately 250,000 seat belt citations were reported during the enforcement period. The Table that follows shows that the rate of ticketing per resident ranged widely in all three study groups: 9 to 40 per 10,000 residents in Full Implementation states; 5 to 19 in Other Implementation states; 10 to 36 in Comparison states. Generally, the states with standard, or "primary,", seat belt use laws (AL, IA IN, MI, NY, OR, TX) issued tickets at a greater per resident rate. Highest ticketing rates included Alabama (31), Indiana (40) and Texas (40) among the Full Implementation states and Comparison state, New York (36).

\footnotetext{
${ }^{1}$ The Texas program centered around the 10 largest cities in the state. An estimated $80 \%$ of the state's population was covered.

${ }^{2}$ Primary belt use laws allow an officer to stop or cite a motorist for a belt use violation alone. Remaining states have "secondary" laws under which the officer must first stop or cite the motorist for some other violation before a belt ticket can be issued.
} 
Amounts Spent Placing Paid Advertisements

\begin{tabular}{lrr}
\hline & $\begin{array}{c}\text { Estimated Dollars Spent } \\
\text { on Paid Advertisements }\end{array}$ & $\begin{array}{c}\text { Amount (Cents) } \\
\text { per Resident }\end{array}$ \\
\hline Full Implementation & 251,512 & 6 \\
AL & $2,912,921$ & 13 \\
FL & $1,000,000$ & 8 \\
IL & 963,089 & 16 \\
IN & 330,000 & 12 \\
MS & 290,000 & 14 \\
NV & $1,045,880$ & 16 \\
TX (Ten Largest Cities) & 200,000 & 33 \\
VT & 500,000 & 8 \\
WA & 250,000 & 14 \\
WV & & \\
Other Implementation & 100,000 & 2 \\
CO & 650,000 & 6 \\
MI & 433,328 & 4 \\
OH & 27,000 & 2 \\
RI & & 0 \\
Comparison & 0 & 0 \\
IA & 0 & 0 \\
NY & 0 & 0 \\
OR & 0 & \\
West MA & & \\
\hline
\end{tabular}

sTEP Wave Enforcement Summary

\begin{tabular}{lrr}
\hline & Seat Belt & Tickets per \\
& Citations & 10,000 Residents \\
\hline Full Implementation & 13,664 & 31 \\
AL & 37,063 & 23 \\
IL & 22,073 & 18 \\
IN & 24,697 & 40 \\
MS & 2,486 & 9 \\
NV & 3,570 & 17 \\
TX (Ten Largest Cities) & 27,260 & 40 \\
VT & 1,304 & 21 \\
WA & 5,505 & 9 \\
WV & 3,104 & 17 \\
Other Implementation & & \\
CO & 3,026 & 7 \\
MI & 5,463 & 5 \\
OH & 21,790 & 19 \\
RI & 1,301 & 12 \\
Comparison & & \\
IA & 3,033 & 10 \\
NY & 69,034 & 36 \\
OR & 5,745 & 17 \\
West MA & 818 & 24 \\
\hline
\end{tabular}




\section{Results}

\section{Pre/Post Changes in Belt Use}

The front seat occupant belt use rate improved in all of the Full Implementation states; three of four in the Other Implementation group; and two of four in the Comparison group. Vermont (18.7 percentage points) and West Virginia (15.1) improved noticeably more than others among the Full Implementation group; Ohio (6.1) and Rhode Island (6.0) improved most among the Other Implementation group; and New York (4.5) among the Comparison group.

On average, improvement was greatest among the Full Implementation group (8.6), less across the Other Implementation group (2.7) and least across the Comparison group (0.5). Baseline belt use rates were typically higher among primary law states, compared to secondary law states. Post program survey results indicated the same pattern. Belt use across the Comparison states started higher and ended higher than the other two study groups and improved least; three of four Comparison states have a primary law. Among the Full Implementation group, increases occurred in states either primary or secondary and with either high or low baselines.

Observed Changes in the Seat Belt Use Rate by State

\begin{tabular}{|c|c|c|c|}
\hline & Baseline & Post & $\begin{array}{r}\text { Estimated } \\
\text { Change }\end{array}$ \\
\hline Full Implementation & $(\mathrm{N}=312,172)$ & $(\mathrm{N}=324,895)$ & \\
\hline AL $\quad(116,064)$ & 70.3 & 78.7 & +8.4 \\
\hline$(60,705)$ & 66.5 & 75.1 & +8.6 \\
\hline$(69,025)$ & 70.6 & 74.3 & +3.7 \\
\hline$(39,491)$ & 69.2 & 72.2 & +3.0 \\
\hline$(218,347)$ & 53.8 & 61.5 & +7.7 \\
\hline$(40,000)$ & 70.6 & 76.4 & +5.8 \\
\hline$(30,016)$ & 80.5 & 86.4 & +5.9 \\
\hline$(19,779)$ & 66.2 & 84.9 & +18.7 \\
\hline$(12,089)$ & 80.8 & 89.5 & +8.7 \\
\hline$(31,551)$ & 56.5 & 71.6 & +15.1 \\
\hline Average & 68.5 & 77.1 & +8.6 \\
\hline Other Implementation & $(\mathrm{N}=185,173)$ & $(\mathrm{N}=188,857)$ & \\
\hline $\begin{array}{ll}\mathrm{CO} & (291,450)\end{array}$ & 72.1 & 73.2 & +1.1 \\
\hline$(30,248)$ & 82.3 & 80.0 & -2.3 \\
\hline$(44,240)$ & 64.2 & 70.3 & +6.1 \\
\hline$(8,092)$ & 62.6 & 68.6 & +6.0 \\
\hline Average & 70.3 & 73.0 & +2.7 \\
\hline Comparison & $(\mathrm{N}=118,761)$ & $(\mathrm{N}=122,247)$ & \\
\hline$\overline{I A} \quad(23,898)$ & 81.4 & 83.0 & +1.6 \\
\hline$(175,328)$ & 78.3 & 82.8 & +4.5 \\
\hline$(36,115)$ & 88.5 & 87.8 & -0.7 \\
\hline West MA $\quad(5,667)$ & 60.6 & 57.2 & -3.4 \\
\hline Average & 77.2 & 77.7 & +0.5 \\
\hline
\end{tabular}


Full Implementation states not only reported baseline and post survey results, but also duringprogram measurements of the belt use rate. That is, measurements were made at the end of specific program periods: earned media only; paid media before enforcement; and the enforcement period. The Figure below shows results from these surveys. Results are consistent across the sites in that the largest belt use increases occurred after the enforcement period began.

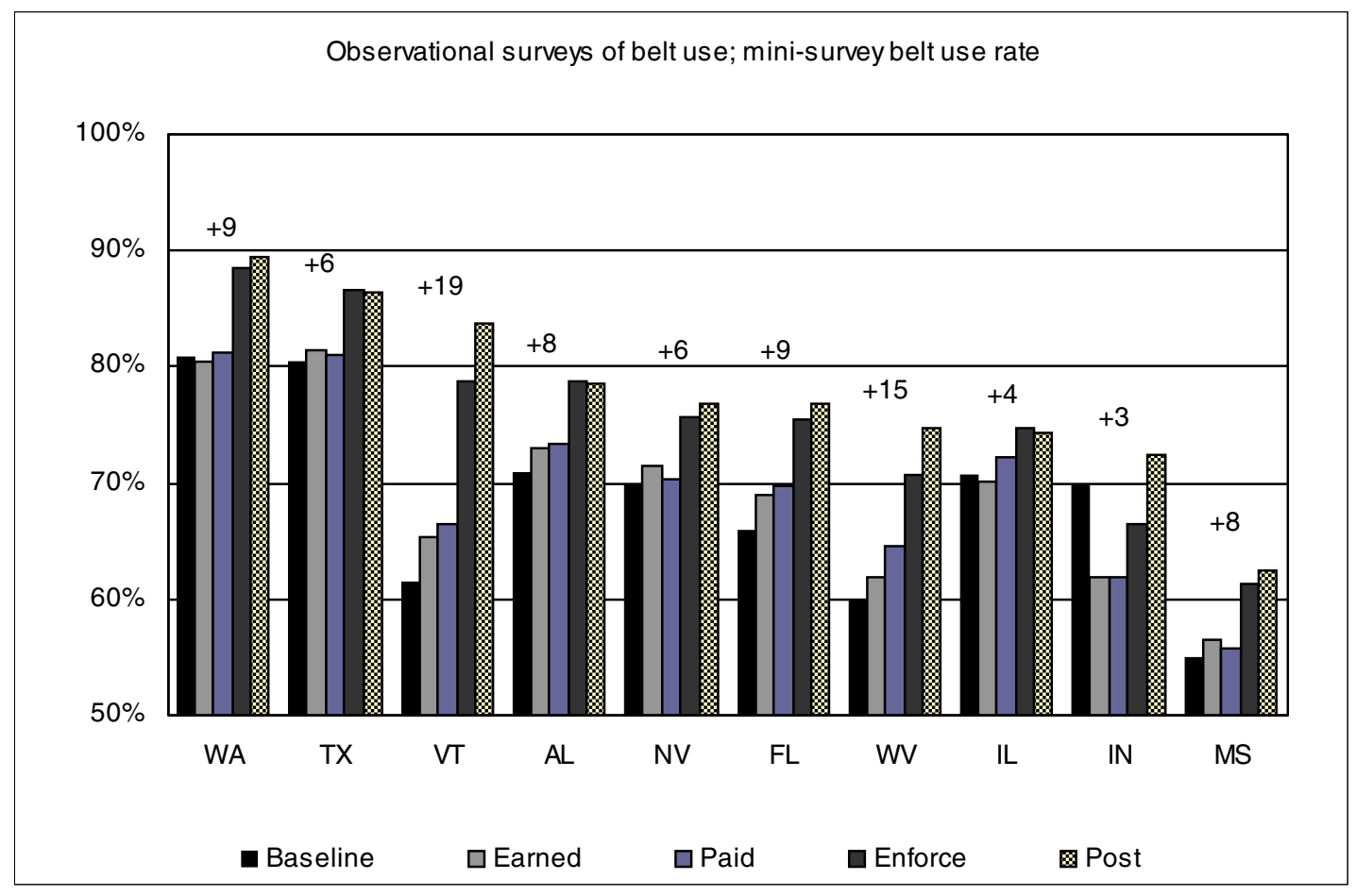

\section{Pre/Post Telephone Survey Results}

Results from telephone surveys $(\mathrm{N}=18,328)$ indicated that residents in all states became more aware of enforcement programs over time. Results also indicated that respondents perceived an increase in enforcement activity towards seat belt use. Increases in awareness and perceived enforcement activity were sharpest among Full Implementation states compared to states in the other two study groups.

The figures that follow show selected results from Pre and Post telephone surveys. Baseline results are represented as the light-gray segments in the bar graph. Dark-gray segments represent increases measured by the post-survey.

In the baseline survey, some thirteen percent of respondents indicated that in the past 30 days they had seen or heard messages announcing seat belt enforcement. Post survey results showed increases in affirmative responses in every state with the largest increases taking place in the Full Implementation group.

Respondents were asked if they agree that police are writing more tickets now compared to a few months ago. The proportion of respondents who indicated they "strongly agree" with this statement increased in every study site, increasing most among those in the Full Implementation group. 

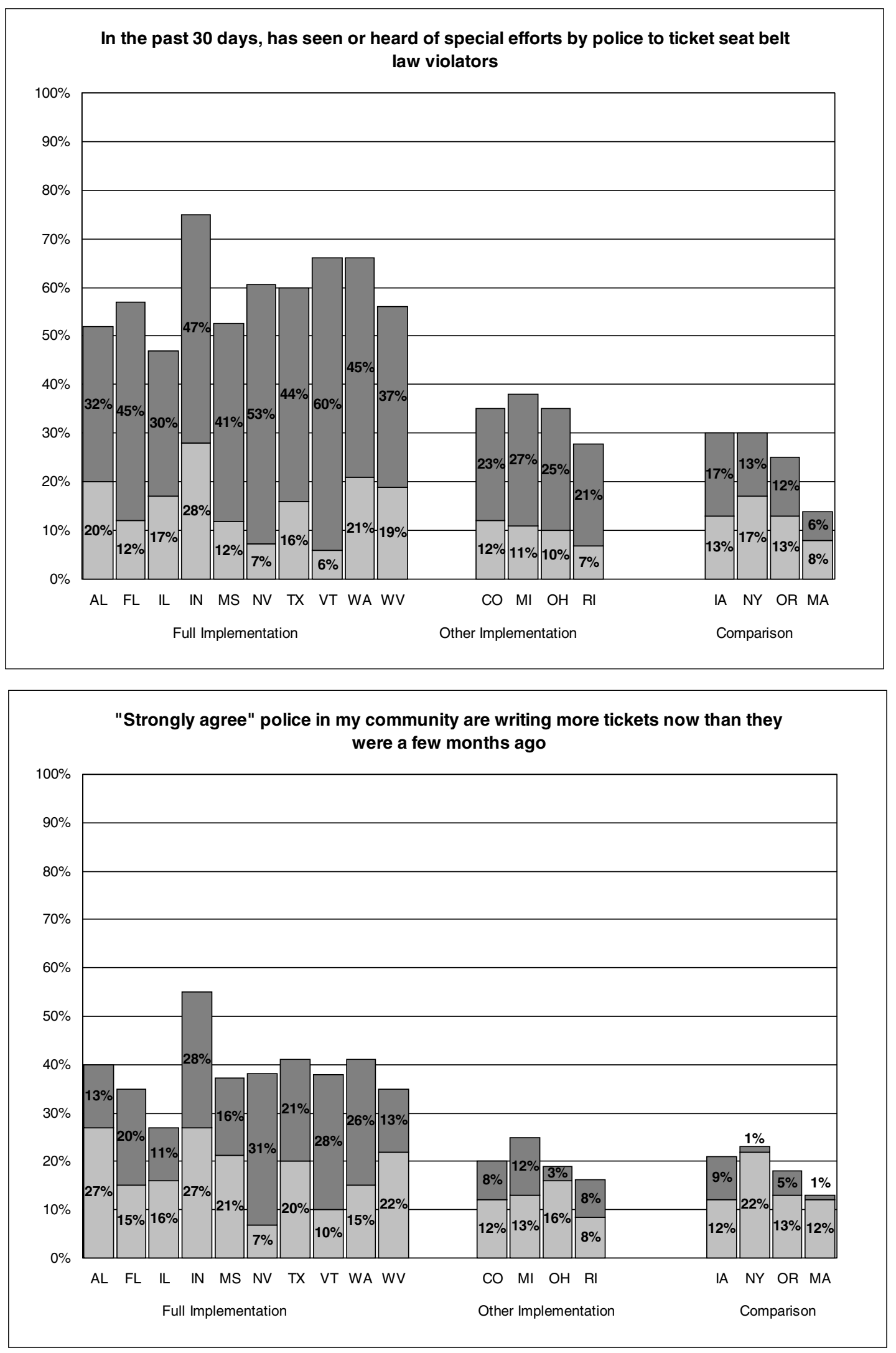


\section{DMV Driver Survey}

The figures that follow show wave results from driver surveys collected in intervals at Driver Licensing Offices in seven of ten Full Implementation states $(\mathrm{N}=44,319)$.

Results indicated that a majority of drivers became aware of the stepped up enforcement around the time that actual enforcement began and that the intensive publicity campaign was an obvious reason for the heightened awareness. More than half of the respondents in all states, except Illinois, had recently seen or heard a belt enforcement message by the time enforcement began.

Actual stepped up enforcement was evident given that over the course of the program respondents were more likely to report personally experiencing seat belt enforcement activity. Personal experience with enforcement increased in every state. As expected, increases generally were measured after enforcement began.

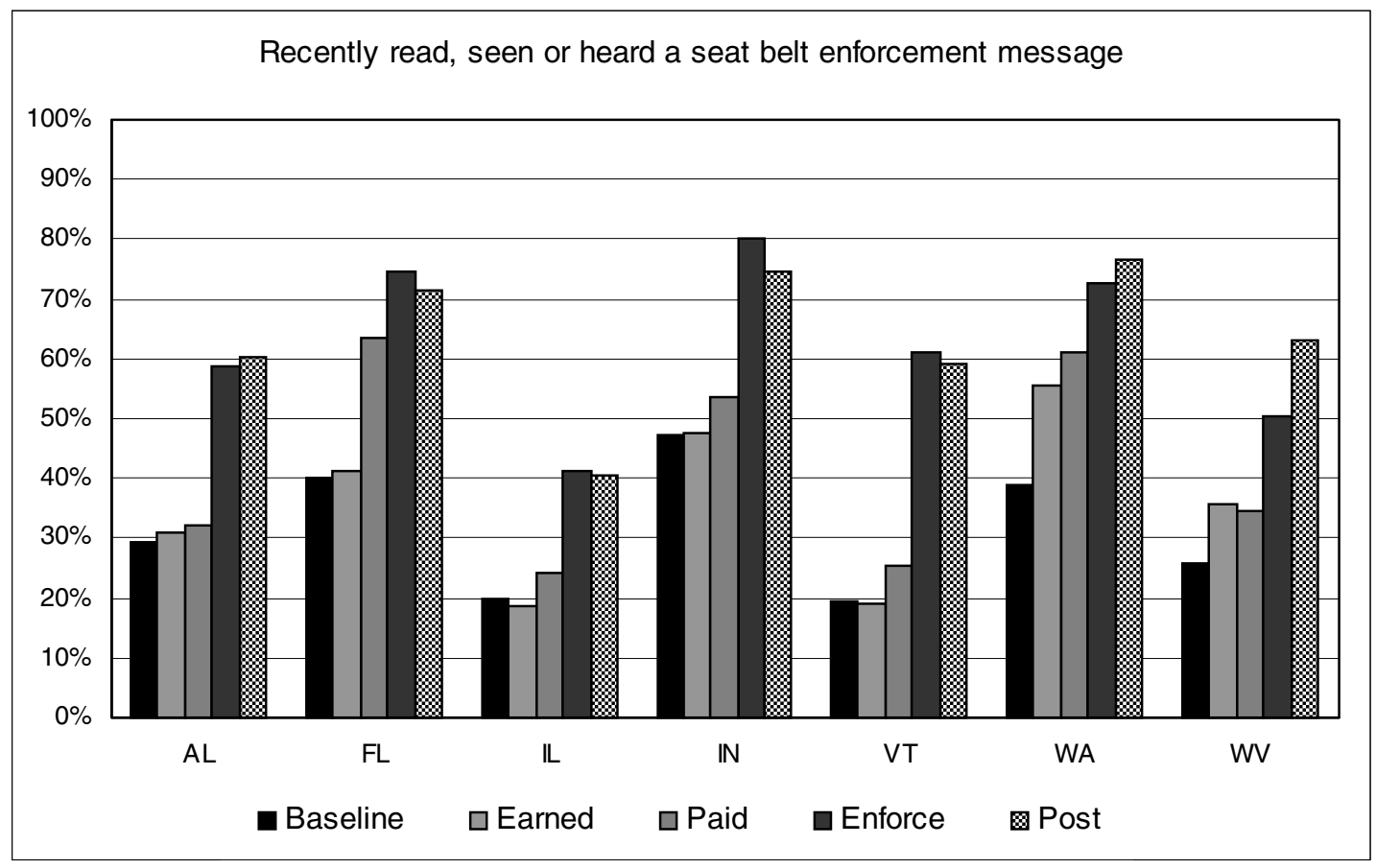




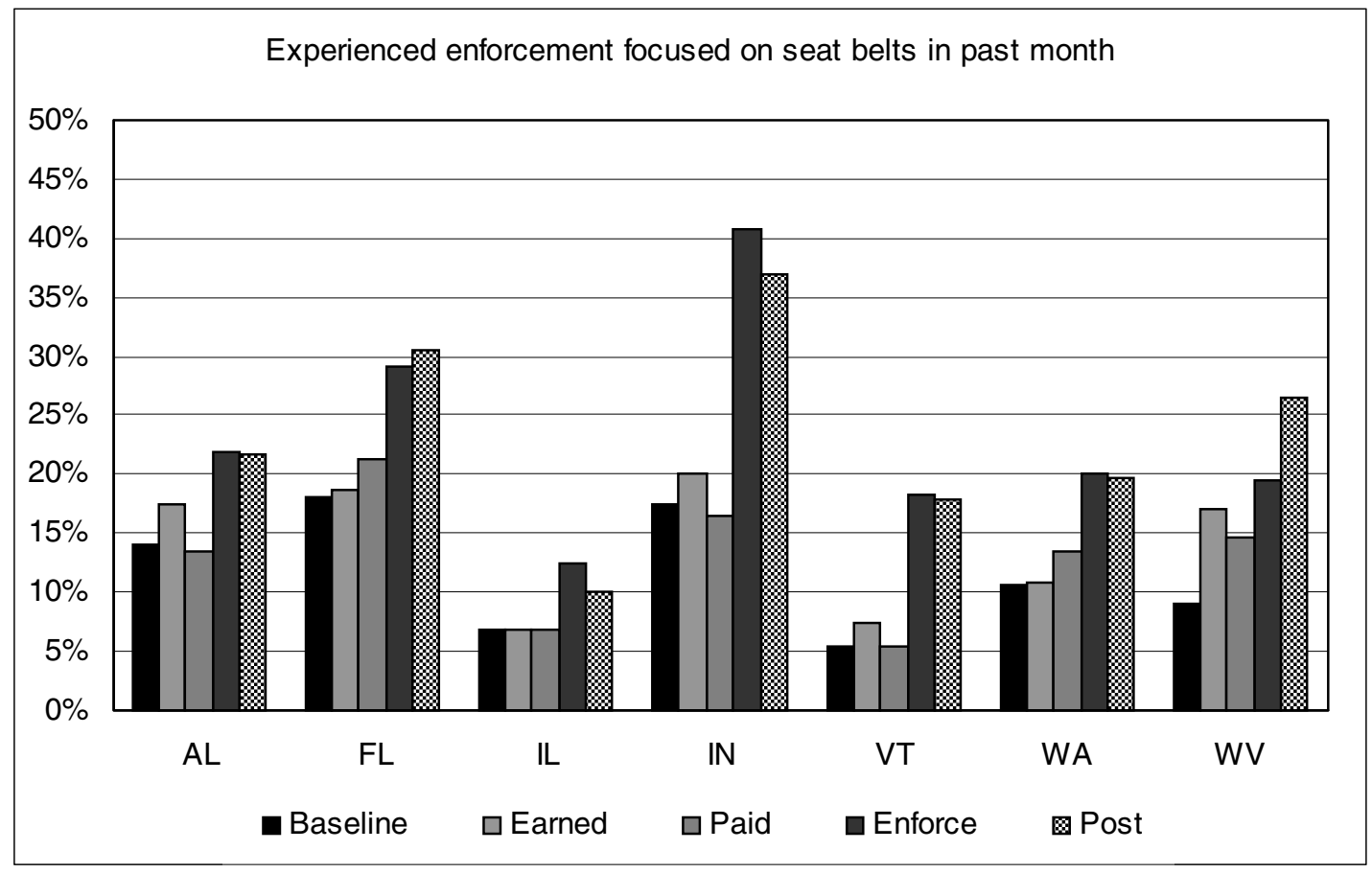

\section{Discussion}

The present evaluation of the May 2002 Click It or Ticket programs involved 10 states from around the country that fully implemented the program's elements and timetable. Collectively, these states issued more than 139,000 seat belt tickets in the two-week enforcement phase. Seat belt use rose by between 3.0 and 18.7 percentage points with an average increase of 8.6 percentage points. The largest gains in seat belt use came near the end of the enforcement phase and generally did not appear during the media only phases. Results from driver surveys indicated that there was a high awareness of media messages, the Click It or Ticket slogan in particular and seat belt enforcement activities.

There were four states that provided evaluation data for efforts that differed in some respect from the full Click It or Ticket model. Statewide belt use rose by 6.1 percentage points in Ohio, which conducted an extended period media effort that publicized a non-enforcement message "What's Holding You Back." Rhode Island and Colorado used only modest scale radio advertisements as their paid media. Belt use increased by 6.0 points in Rhode Island and by only 1.1 percentage points in Colorado. Belt use declined by 2.3 points in Michigan, in which Click It or Ticket was conducted in only a part of the state and the program's period of enforcement lasted just four days.

Belt use across four Comparison states started higher and ended higher than the other two study groups and improved least. The four comparison sites did not place paid advertisements but did engage in enforcement activities and showed belt use changes that ranged from -3.4 points to +4.5 points. New York State had among the highest rates of belt citation of all of the states studies. New York did not pay for placement of advertisement at specific times, but was invested in a program of Non-Commercial Sustaining Announcements from which the state received airings of the program's message. Absent paid advertisement placement the effort generated the largest increase in belt use among comparison states, 4.5 percentage points. 
The results of this evaluation confirmed that intensive, short term and well-publicized enforcement produces large gains in seat belt use. The results also suggest that enforcement with only modest paid media and intensive enforcement with no paid media will have some effect but not to the extent of the full Click It or Ticket implementation. 


\section{TABLE OF CONTENTS}

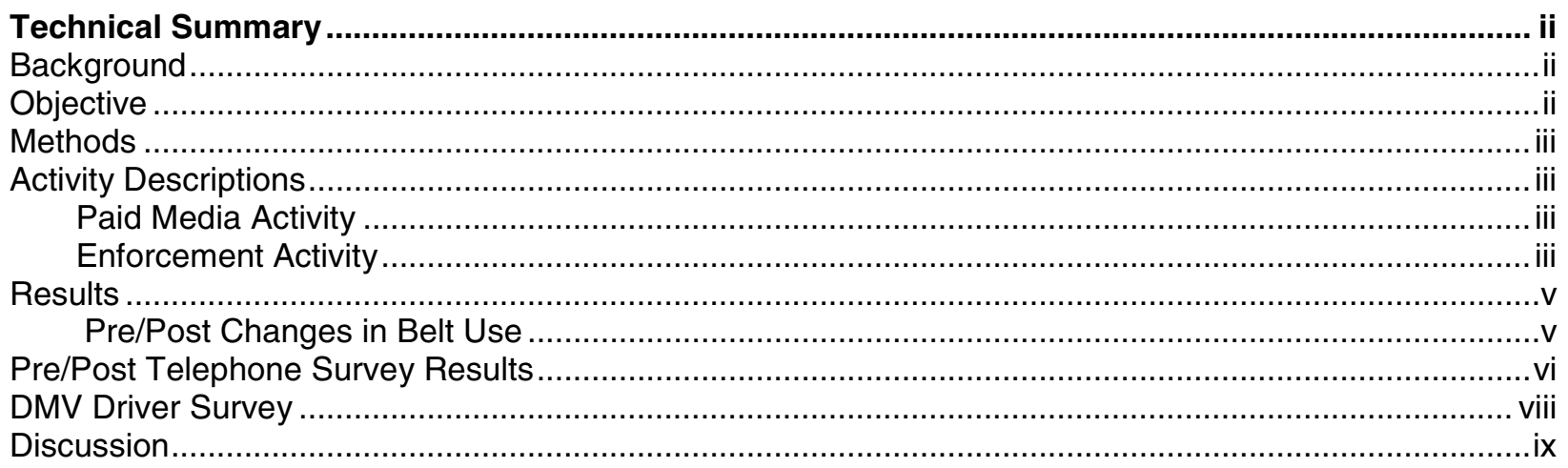

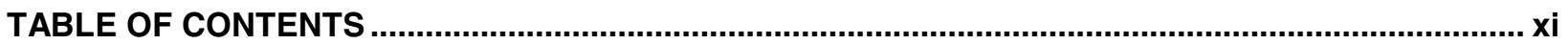

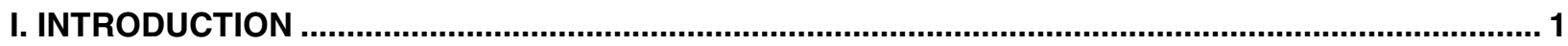

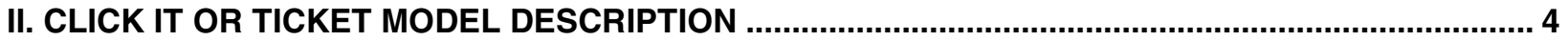

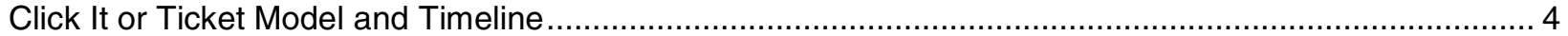

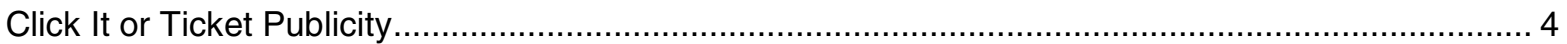

Earned Media

Paid Media

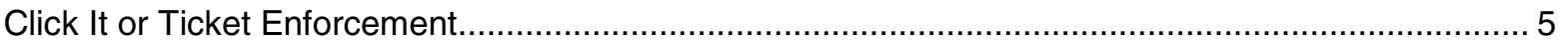

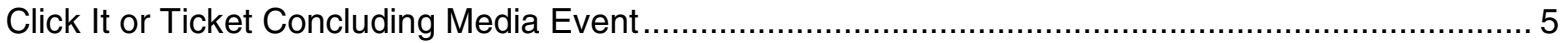

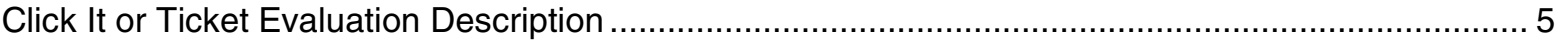

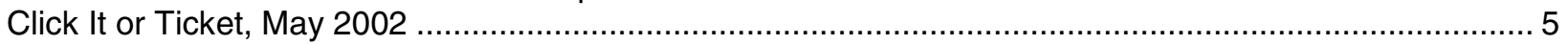

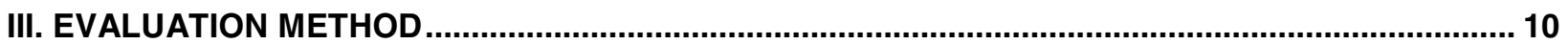

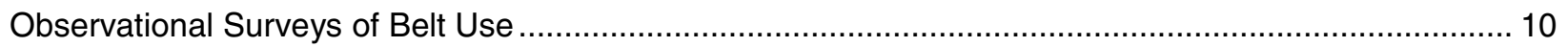

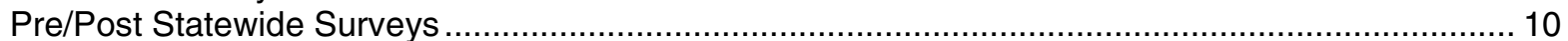

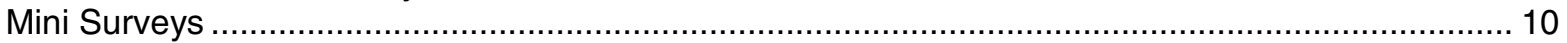

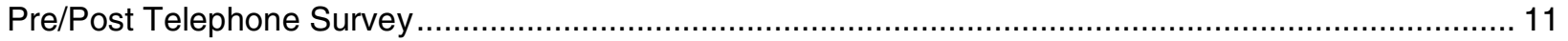

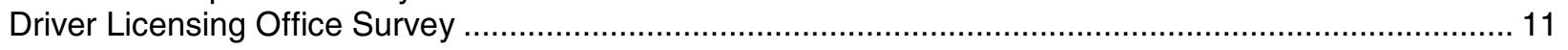

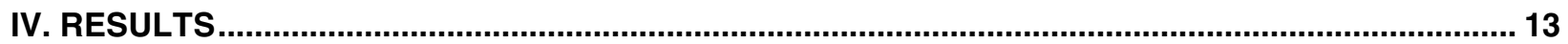

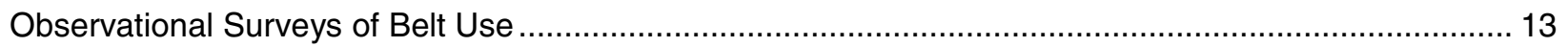

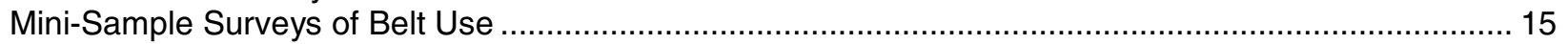

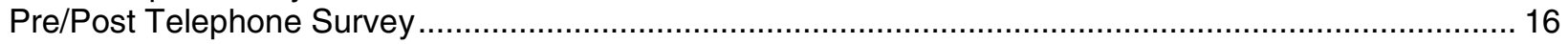

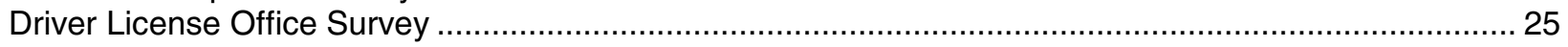

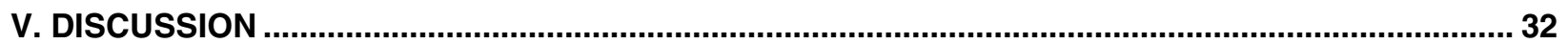

REFERENCES

APPENDICES

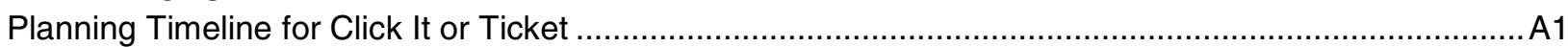

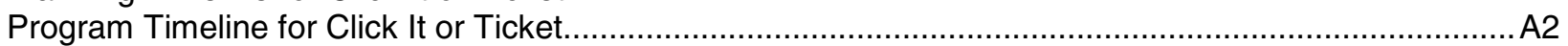

Sample - Seat Belt Survey - Data Collection Form ..................................................................... B1

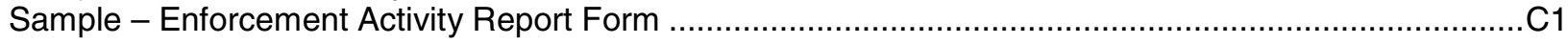

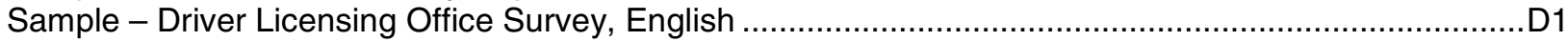

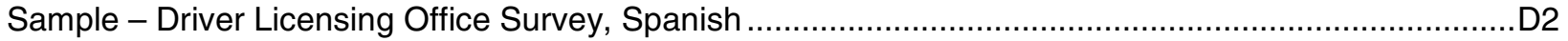

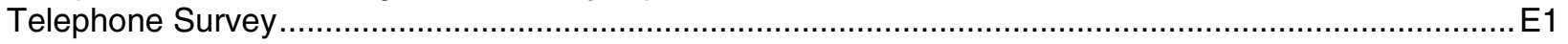





\section{INTRODUCTION}

Selective Traffic Enforcement Programs (sTEPs) are a proven method to change motorists' behavior and do it quickly. Occupant protection sTEPs can raise seat belt use rates more substantially and more quickly than any other currently available program as they create a perception among motorists that they will be ticketed if they do not buckle up.

sTEP programs typically span a few weeks time with the first and second weeks focused on publicity and the remaining weeks concentrated on publicity combined with intense and highly visible enforcement.

Canada was the first country in North America to demonstrate that highly publicized occupant protection enforcement increases compliance with occupant protection laws. In the mid-1970s, mandatory seat belt laws were passed in the Canadian provinces. Within months, the seat belt use rate surged to as high as 71 percent. However, shortly thereafter, the use rate declined. Years later occupant protection sTEPs used in several provinces led to sharp increases in seat belt use (Jonah et al., 1982; see also Williams et al., 2000). Continued use of sTEPs contributed to Canada's achievement of an 87 percent use rate by the 1990s.

New York State experienced a similar rise and fall in its seat belt use rate following passage of the first statewide seat belt law in the U.S. in 1984. In 1985, the community of Elmira in Chemung County, NY conducted a three-week publicity and enforcement program based on the Canadian sTEP model. The Elmira sTEP effort, the first in the U.S., successfully reversed a falling seat belt use rate. The use rate improved from 49 percent to 77 percent in just three weeks time (Williams et al., 1987).

North Carolina enacted a seat belt law in 1986. Shortly thereafter, police officers began issuing tickets and seat belt use rose to 78 percent, higher than anywhere else in the country. By the middle of 1993, the rate had dropped to 65 percent. North Carolina decided to embark on a long-term program to increase its seat belt use rate in 1994. The program was named "Click It or Ticket" and it was the first statewide occupant protection sTEP attempted in the U.S.

North Carolina began by using a sTEP model resembling the Canadian and Elmira programs. High levels of seat belt and child restraint use were achieved using stepped up enforcement, increased publicity and widespread public information and education focusing on enforcement. By July 1994, sTEPs in North Carolina had achieved an 81 percent driver seat belt use rate (Insurance Institute for Highway Safety, 1994).

Between 1995 and 1997, NHTSA funded statewide occupant protection sTEPs in over two-dozen states under the auspices of the Campaign Safe and Sober program. These states conducted an average of four sTEP waves for each year of funding. Most of these programs garnered widespread law enforcement support. But unlike Click It or Ticket in North Carolina, none of these programs extensively used paid media. Instead, these states relied heavily on earned media and public service announcements to get their message to the public. Furthermore, program publicity was not always focused on stepped up enforcement, but rather on health and safety themes. All of these sTEP states experienced measurable increases in belt use over time, though the wave-to-wave increases were usually small (Solomon et al., 1999).

In November 2000, South Carolina adopted the Click It or Ticket program. This sTEP program included both an earned and paid media effort supported by a grant $(\$ 500,000)$ from the Air Bag and Seat Belt Safety Campaign. Both the paid and earned media efforts focused exclusively on occupant restraint enforcement. During a two-week enforcement period, the South Carolina Highway Patrol, in association 
with local law enforcement, conducted 3,303 checkpoints and wrote 19,815 belt use citations. By the end of the two-week enforcement period, 80 percent of motorists surveyed at DMV offices reported knowing of Click It or Ticket; 82 percent heard about checkpoints; and 40 percent had actually gone through a checkpoint. Observed front seat occupant belt use increased by 14 percentage points, from 65 percent before enforcement to 79 percent during the second enforcement week (Solomon and Preusser, in process).

Shortly after South Carolina's successful Click It or Ticket campaign, a partnership among NHTSA Region IV officials, the Air Bag and Seat Belt Safety Campaign and state highway safety officials was formed to conduct a Click It or Ticket program across the southeast. All eight states in the region, Alabama, Florida, Georgia, Kentucky, Mississippi, North Carolina, South Carolina and Tennessee participated. The May 2001 program was structured so that all of the states simultaneously undertook a five-week earned media campaign, a two week paid media campaign beginning one week after the start of earned media, and a two week intensive enforcement effort beginning one week after the start of paid media. Locally conducted, pre, during and post observations of belt use and surveying of awareness of the program were also carried out. Some 3,250 law-enforcement agencies participated in the program, conducting over 25,000 checkpoints or patrols during the two-week enforcement period. Enforcement resulted in 119,805 seat belt citations, 9,495 child restraint citations, 8,478 DUI arrests, recovery of 254 stolen cars and apprehension of 1,471 fugitives. Results of surveys conducted in driver licensing offices throughout the eight states showed a dramatic increase in awareness of recent seat belt messages on television and radio, as well as in the print media. Observations of seat belt use showed statewide increases of between four and twenty percentage points across the states (Solomon, 2002).

Evaluation of the southeast region-wide program provided evidence that the full implementation of the Click It or Ticket model, specifically the use of paid media, can contribute to an improved belt use rate. The study states, though, were all within one geographical region. To evaluate more widespread application of the Click It or Ticket model and to measure its effectiveness, a wider geographical range of states would be needed.

The availability of federal grants for seat belt enforcement under the Transportation Equity Act for the $21^{\text {st }}$ Century (TEA-21) has made periodic seat belt enforcement sTEPs commonplace in the U.S. TEA-21 funds have only recently been directed towards funding paid advertisement campaigns, telling motorists to put on a seat belt or else be ticketed. During spring 2002, the National Highway Traffic Safety Administration approached at least one state in each of its ten Regions, looking for highway safety offices willing to organize and implement a Click It or Ticket or similar program in May 2002. These states would be asked to:

- Carry out a Click It or Ticket model program;

- Follow established timeline for activities;

- Saturate television and/or radio media markets with enforcement focused paid advertisements;

- Vigorously enforce the seat belt law;

- Use Click It or Ticket or like slogan;

- Conduct evaluation model.

TEA-21 required NHTSA to evaluate the effectiveness of paid media efforts in increasing seat belts use. In turn, NHTSA requested a study to address May 2002, Click It or Ticket model programs and specifically the use of paid advertisements to increase seat belt use. 
This report presents results from an evaluation of 18 study states using Occupant Protection Selective Traffic Enforcement Programs to increase the seat belt use rate. Ten study states organized and fully implemented Click It or Ticket type programs that included the extensive use of paid advertisements. Four study states organized and implemented Click It or Ticket type programs that included the use of paid advertisements, but differed in some regards to full implementation of the Click It or Ticket program model. Four states conducted Selective Traffic Enforcement Programs and used no paid advertisements to publicize their enforcement campaign. 


\section{CLICK IT OR TICKET MODEL DESCRIPTION}

\section{Click It or Ticket Model and Timeline}

A Click It or Ticket (COT) program is an occupant protection Selective Traffic Enforcement Program (sTEP). The enforcement is fully supported with intensive paid publicity that focuses primarily on enforcement of occupant restraint laws. The model program includes 1) data collection, before, during and immediately after media and enforcement phases; 2) earned and paid publicity announcing strict enforcement; 3) highly visible enforcement each day of the two-week enforcement period; and 4) a media event announcing program results and thanking all the participants in the community (Figure 1). (For more descriptions of Planning Timelines and Program Timelines see Appendix A).

Figure 1. Click It or Ticket Model and Timeline

\begin{tabular}{|c|c|c|c|c|c|c|c|c|}
\hline & \multicolumn{8}{|c|}{ Program Weeks } \\
\hline & 1 & 2 & 3 & 4 & 5 & 6 & 7 & 8 \\
\hline \multicolumn{9}{|l|}{ Program } \\
\hline \multicolumn{9}{|l|}{ Click It or Ticket Publicity } \\
\hline \multicolumn{9}{|l|}{ Earned media } \\
\hline \multicolumn{9}{|l|}{ Paid media } \\
\hline \multicolumn{9}{|l|}{ Click It or Ticket Enforcement } \\
\hline \multicolumn{9}{|l|}{ Concluding Media Event } \\
\hline \multicolumn{9}{|l|}{ Program Evaluation } \\
\hline \multicolumn{9}{|l|}{ 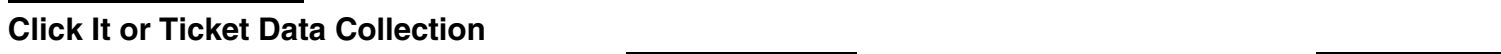 } \\
\hline Statewide belt use observations & \multicolumn{2}{|c|}{ Baseline } & & & & & \multicolumn{2}{|c|}{ Post } \\
\hline \multicolumn{9}{|l|}{ Mini sample belt observations } \\
\hline DL Office driver survey & & Baseline & & & & & Post & \\
\hline Resident telephone survey & & Baseline & & & & & Post & \\
\hline
\end{tabular}

Click It or Ticket Publicity

The Click It or Ticket model includes both earned and paid media. Seat belt enforcement messages are repeated over and over during the publicity period. Messages specifically stay focused on enforcement continuing to remind motorists to buckle up or receive a ticket, in other words "Click It or Ticket."

\section{Earned Media}

Earned media is where program details and results are developed into newsworthy events that are circulated into the public by broadcasters and newspapers. Earned media generally begins one-week before paid media, two weeks before enforcement, and continues throughout other phases of the program. An earned media event, like a press conference and press release, is typically used to announce the ensuing enforcement program. Additional events continue to bring news coverage to the ongoing enforcement effort. Press releases can be used to update the public on the latest program details.

\section{Paid Media}

Click It or Ticket paid advertisement campaigns usually last two weeks. During this period, radio and television advertisements air extensively. Paid advertisements are strategically placed at times and places intended to maximize exposure. Typically, both radio and television advertisements are timed to air at pre-selected times that maximized exposure. Paying for advertisement placement is necessary to reach the largest audience and specific target groups. Radio advertisements, timed to run during drive 
times, attempt to reach motorists when they most likely are in their vehicles. Television advertisements are run at times when most viewers are present. Additionally, some of the television and radio airtime may be strategically placed to reach low belt use target groups (i.e. youth, pickup truck occupants, rural populations, etc.).

\section{Click It or Ticket Enforcement}

Click It or Ticket enforcement campaigns usually last two-weeks. During this period, zerotolerance enforcement focusing on seat belt violations is carried out statewide. Ideally traffic enforcement stays focused on seat belt violations above all other traffic violations. Making seat belt use the principal focus for enforcement may be easier in locations with seat belt laws allowing for standard enforcement. That is, compared to locations with secondary laws (where a driver must be stopped for some other violation before a citation for non-use can be issued). But focusing on seat belts is possible in both legal environments. Various enforcement techniques used during the period of enforcement may include, checkpoints, saturation patrols and routine patrols. Checkpoints are ideal because of their high visibility. Whatever enforcement tactics are used, keeping traffic enforcement visibly present for the entire enforcement period is a central component of CIOT.

\section{Click It or Ticket Concluding Media Event}

Weeks after ending Click It or Ticket publicity and enforcement, a concluding media event is used to publicize results. Program results and recognition of contributions from the community are supplied to the media for public exposure.

\section{Click It or Ticket Evaluation Description}

Click It or Ticket programs are evaluated in a number of ways. Observed seat belt use and motorists' attitudes and knowledge of police activity are tracked. Data are collected week-by-week; before, during and at the height of the enforcement effort and just after the conclusion of special enforcement and media activities. Evaluation methods are explained in more detail in the next chapter.

\section{Click It or Ticket, May 2002}

During spring 2002, states throughout the U.S. organized sTEP programs for the May 2002 National Mobilization for the enforcement of seat belt laws. National Mobilizations are annual efforts largely funded by TEA-21 grant money. This study evaluated results from 18 study states conducting sTEP wave programs surrounding the May 2002 National Mobilization. Study states were classified into one of three groupings. The groups are defined below.

Full Implementation States - Statewide program employing all elements of the Click It or Ticket model: defined periods of earned media, paid media, and intensive enforcement; specific paid advertisement placement using "Click It or Ticket" or similar direct enforcement message; program evaluation involving before, during and after belt use observations and surveys of public perceptions of the program. Ten states: Alabama, Florida, Illinois, Indiana, Mississippi, Nevada, Texas $^{3}$, Vermont, Washington and West Virginia.

Other Implementation States - Divergence from full implementation of Click It or Ticket model. Specific paid advertisement placement. Four states: Colorado, Michigan, Ohio and Rhode Island. Colorado followed the model's timeline but only conducted modest paid media using radio. Rhode Island conducted a compact, all-inclusive two-week media/enforcement program and only used a modest amount of paid advertisements using radio. Michigan's program covered only a portion of the state and used a four-day enforcement period instead of the

\footnotetext{
${ }^{3}$ The Texas program centered around the 10 largest cities in the state. An estimated $80 \%$ of the state's population was covered.
} 
designated two-weeks of the Click It or Ticket model. Ohio's paid media effort extended for a much longer time period than the designated recommended three weeks of the Click It or Ticket model.

Comparison States - Divergence from full implementation of Click It or Ticket model. Absence of specific paid advertisement placement. Four states: Iowa, New York; Oregon; and western Massachusetts.

Seat belt enforcement sTEPs were conducted in all of these states as part of the annual May mobilization that is encouraged nationally. Among the four states, there were expectations that Public Service Announcements (PSAs) would be airing courtesy of state broadcasters' associations, with whom these states expressed having long lasting working relationships and from which they have received a steady level of in-kind publicity for years. The dollar value of in-kind airings were expected to be relatively small compared to the dollar amounts that Full Implementation states were spending and receiving. These states are treated here as comparison sites based on their lack of use of paid advertisement placement.

\section{Paid Media Activity Description}

All eighteen-study states had previous experience conducting occupant protection sTEPs and all eighteen put considerable levels of effort into planning and implementing publicity for their May 2002 sTEP programs.

Earned and paid media carried the "Click It or Ticket" slogan in all but one Full Implementation state. Nevada, the exception, used a slogan that suggested enforcement, "No Excuses, No Exceptions, Buckle Up." Ohio, the only Other Implementation state that did not use the CIOT slogan, advertised a non-enforcement slogan "What's Holding You Back?" Only one of four Comparison sites, New York, publicized "CIOT." The other three used non-enforcement slogans. Iowa used "Show a Little Restraint," Oregon "Life is Good - The Way to Go" and western Massachusetts "Buckle Up Massachusetts."

States using paid advertisement placement had to put additional resources towards coordinating paid media campaigns. In nearly all of the states using advertisement placement, assistance was provided by the media firm Greer, Margolis, Mitchell and Burns, Inc. Assistance may have included the production of advertisements, media market analyses and the process of negotiating and purchase of airtime. A number of states used local media firms to assist the media coordination.

Among the 14 states buying advertisement placement, campaigns usually lasted two-weeks. Radio and television advertisements were developed and aired extensively. Both radio and television advertisements aired at pre-selected times that maximized exposure. Radio advertisements, timed to run during drive times, attempted to reach motorists when they most likely were in their vehicles. Television ad spots ran at times when most viewers were present. Additionally, some of the television and radio airtime was strategically placed to reach low belt use target groups (i.e. youth, pickup drivers, rural populations, etc.).

Paid advertisements generally began one week before enforcement and continued airing during the first week of enforcement. Approximately $\$ 8,153,730$ was spent to buy airtime across the 14 study states that used paid advertisements. Media outlets provided additional airings without charge (free spots and "matching dollar" spots). Table 1 shows estimated dollar amounts spent on placing paid advertisements by each state during the mobilization and the amount spent per resident. Free placements, from donated ad spots or matching dollar agreements are not represented in this table since they were not accounted for by all states. Among the full implementation states, the spending ranged from $5.6 \phi$ per resident in Alabama to $32.6 \notin$ per resident in Vermont. Among the Other Implementation states, Colorado 
and Rhode Island conducted only modest paid media, primarily using radio (spending $2.3 \phi$ and $2.6 \phi$ respectively). Michigan and Ohio spent $6.5 \phi$ and $3.8 \phi$ respectively on their paid media campaigns. Since Ohio's paid publicity was spread out over several months' time, the amount spent per resident saturation was not as concentrated as in other states.

Table 1. Amounts Spent Placing Paid Advertisements

\begin{tabular}{lrr}
\hline State & $\begin{array}{c}\text { Estimated Dollars Spent } \\
\text { on Paid Advertisements }\end{array}$ & $\begin{array}{c}\text { Amount (Cents) } \\
\text { per Resident }\end{array}$ \\
\hline Full Implementation & & \\
AL & 251,512 & 5.6 \\
FL & $2,112,921$ & 12.9 \\
IL & $1,000,000$ & 8.0 \\
IN & 963,089 & 15.8 \\
MS & 330,000 & 11.6 \\
NV & 290,000 & 13.8 \\
TX (Ten Largest Cities) & $1,045,880$ & 15.5 \\
VT & 200,000 & 32.6 \\
WA & 500,000 & 8.4 \\
WV & 250,000 & 13.8 \\
Other Implementation & & \\
CO & & 2.3 \\
MI & 100,000 & 6.5 \\
OH & 650,000 & 3.8 \\
RI & 433,328 & 2.6 \\
Comparison & 27,000 & \\
IA & & 0 \\
NY & 0 & 0 \\
OR & 0 & 0 \\
West MA & 0 & 0 \\
\hline
\end{tabular}

Paid advertisement placement was not employed in the comparison states even though some amount of free airtime was expected for PSAs. Free airtime was expected to be relatively small compared to the total spent and received in the Full and Other Implementation states. On the other hand, New York reported receiving coverage through a longstanding relationship between the Governor's Traffic Safety Committee (GTSC) and the New York State Broadcasters Association, Inc. (NYSBA). NYSBA indicated that through the use of Non-Commercial Sustaining Announcements (NCSA; un-purchased advertisement spots donated for public service announcements), GTSC received \$710,725 in advertising value (3.7ф per resident).

Choosing between the valuation received from NCSAs and paying for advertisements is a consideration that has influenced a number of states deciding whether or not to use money to pay for placement of public safety advertisements. Anecdotally, New York and other states report that relationships with local Broadcasters' Associations and longstanding collaboration with local media representatives impact the quality and volume of NCSAs received, thereby adding value to the media campaign. However, even though advertising value can be large, market saturation will most likely be unfulfilled since exact timing of spots cannot be controlled using NSCAs. Saturating a specific target audience within a defined and brief period of time may be difficult to accomplish. 


\section{Seat Belt Enforcement Activity Summary}

Table 2 shows the number of seat belt citations issued during the mobilization for each state and citations issued per 10,000 residents. Enforcement results were dependent not only on level of ticket writing, but also on the number of agencies reporting and completeness in reporting. Several states provided information indicating that far fewer than the total number of participating agencies actually reported and, as such, what is presented in the table and figure below understate total enforcement activities (see sample enforcement report form in Appendix C).

Across all states, more than 250,000 citations were issued for non-compliance with seat belt laws. New York issued by far the most citations, followed by other large population states including Florida and the ten large cities in Texas. The mid-western states, Indiana, Illinois and Ohio, also indicated that their respective law enforcement agencies issued large numbers of seat belt citations.

Looking at the number of citations issued per resident helps to normalize differences in population among the study states. Close to 18 citations per 10,000 residents were issued across all study states. Rate of ticketing ranged widely among individual states and among the three study groups. Ticketing by study group ranged from 9 to 40 among the Full Implementation group and from 10 to 36 among the Comparison group. The Other Implementation group had a narrower and lower range, 5 to 19.

Table 2. Seat Belt Enforcement Activity

\begin{tabular}{lrr}
\hline & $\begin{array}{r}\text { Citations } \\
\text { Issued }\end{array}$ & $\begin{array}{r}\text { Citations per } \\
10,000 \\
\text { Residents }\end{array}$ \\
\hline Full Implementation & & \\
AL & 13,664 & 31 \\
FL & 37,063 & 23 \\
IL & 22,073 & 18 \\
IN & 24,697 & 40 \\
MS & 2,486 & 9 \\
NV & 3,570 & 17 \\
TX (Ten Largest Cities) & 27,260 & 40 \\
VT & 1,304 & 21 \\
WA & 5,505 & 9 \\
WV & 3,104 & 17 \\
& & \\
Other Implementation & & 7 \\
CO & 3,026 & 5 \\
MI & 5,463 & 19 \\
OH & 21,790 & 12 \\
RI & 1,301 & \\
Comparison & & 10 \\
IA & & 36 \\
NY & 3,033 & 17 \\
OR & 69,034 & 24 \\
West MA & 5,745 & \\
\hline
\end{tabular}


The number of citations issued per 10,000 residents is graphed in Figure 2. Several states stand out in the graph because of the large level of ticketing they did. States with the highest level of ticketing were Indiana (40), Texas (40), New York (36) and Alabama (31). All of these states operate under a standard enforcement seat belt law.

It should be noted that the graph below does not account for the number of days of stepped up enforcement conducted. Most programs included a two-week enforcement period. A shorter enforcement period might reflect fewer tickets per resident issued. For example, Michigan, a state with a standard enforcement law for seat belts, conducted only four days of enforcement. Michigan's rate (5 per 10,000) appears relatively low compared to other states.

Figure 2. Seat Belt Tickets Issued per 10,000 Residents

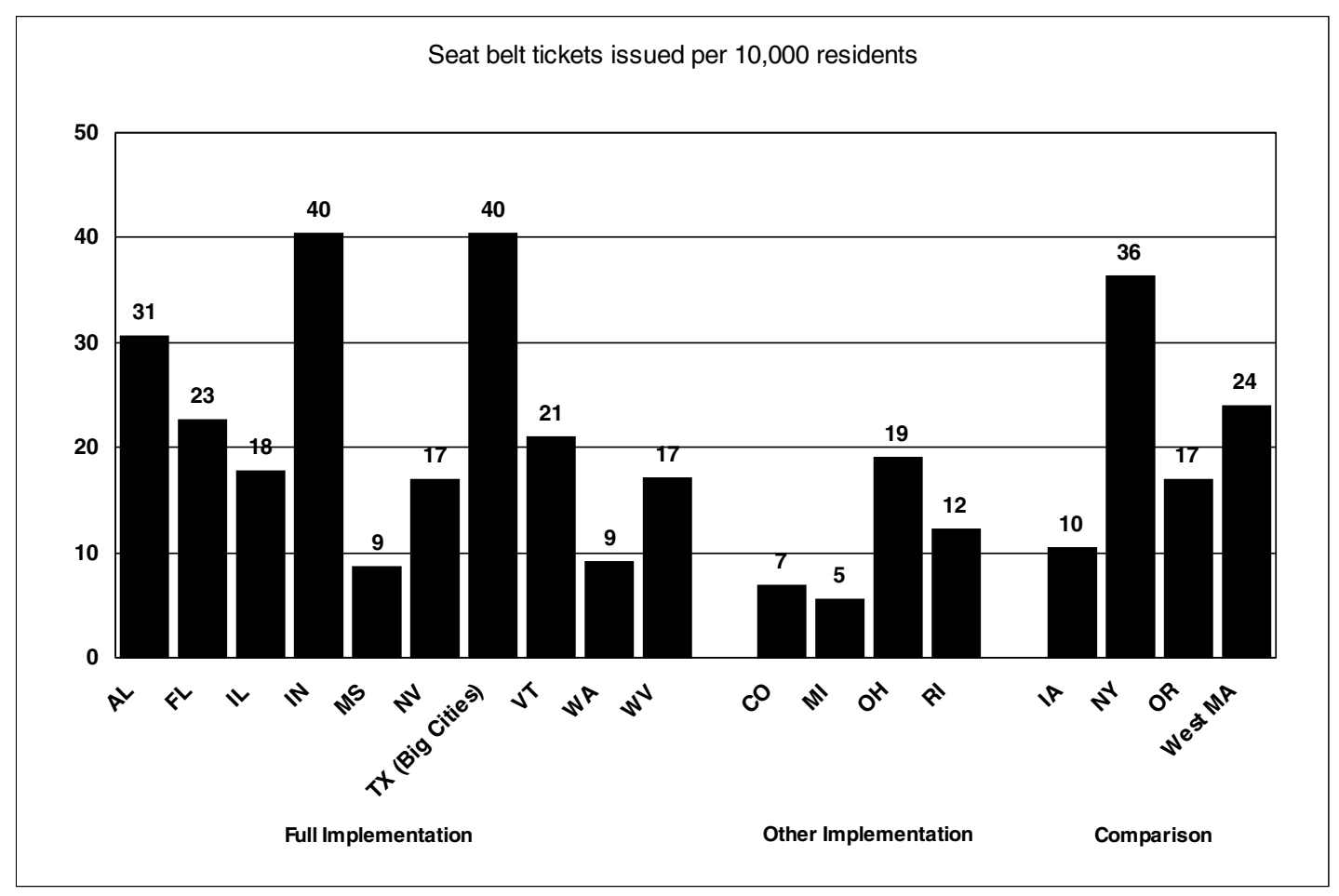




\section{EVALUATION METHOD}

All states committed resources to evaluate their individual effort. National coordination facilitated shared data collection procedures among evaluators in the study states. Most states contracted with researchers at local Universities, some contracted with research evaluation firms and, in a few cases, states used in-house research evaluators to measure program activities and impacts. Preusser Research Group, Inc., (PRG) was a primary conduit for evaluation activities in a number of states. NHTSA contracted with Schulman, Ronca and Bucuvalas, Inc., (SRBI) to conduct pre and post knowledge/ attitude surveys.

\section{Observational Surveys of Belt Use}

All 18 study states conducted observational surveys of seat belt use to track the seat belt use rate. Typically, states collected pre/post data from which changes in the belt use rate were estimated. Comparisons between Full Implementation, Other Implementation and Comparison groups were made.

Statewide observational surveys of belt use and/or mini-observational surveys were used by the study states. Both types are explained below.

\section{Pre/Post Statewide Surveys}

All study states were asked to conduct statewide surveys of belt use just before announcing enforcement activities to the public and immediately following the period of stepped up enforcement and asked that the observational surveys follow NHTSA guidelines for conducting statewide surveys. NHTSA guidelines require that states have a probability-based survey design; that data be collected from direct observation of seat belt use; that the relative error of the seat belt use estimate not exceed five percent; that counties or other primary sampling units totaling at least 85 percent of the State's population be eligible for inclusion in the sample; and that all daylight hours for all days of week be eligible for inclusion in the sample. NHTSA guidelines also requires that the determination of a seat belt use rate to be based on all types passenger motor vehicles including passenger cars, pickup trucks, vans, minivans, and sport utility vehicles and that surveys include observation of both drivers and front seat outboard passengers and both in-state and out-of-state vehicles.

Eight of ten in the Full Implementation group (AL, FL, IN, MS, NV, TX, VT, WV) conducted statewide observational surveys that followed NHTSA guidelines to measure the baseline use rate. All ten conducted a statewide survey following NHTSA guidelines to measure the rate immediately after their program. Only one of the four Other Implementation states $(\mathrm{OH})$ and only one of the four Comparison states (NY) completed both before and after statewide surveys following NHTSA guidelines.

In most cases, pre and post surveys included front seat occupants, including driver or outboard passenger. Some pre and post surveys of belt use included occupant information, such as race, gender, and age, and some identified belt use by vehicle type. (See sample data collection form in Appendix B).

\section{Mini Surveys}

A mini-observational-survey works like a typical statewide survey, but uses a representative subset of observation sites from the broader statewide survey and is completed in a few days' time. Statewide surveys normally take weeks and, in some cases, months to complete. The amount of time it takes to complete a statewide survey is most dependent upon the number of observation sites that are in the survey, the schedule by which these sites are visited, the number of trained observers used to collect data, weather and systems used for entering observation data and methods for analyzing that data. Minisurveys are one way to track a use rate, at intervals, over the course of the program. With that in mind, states can use mini-surveys for measuring program impact at points in time during their program. 
All of the Full Implementation states used mini-observational surveys to track the belt use rate during their program. All of these states conducted three in-program mini-surveys in addition to pre/post surveys. The first in-program mini-survey was conducted during the earned media period before paid advertisements aired; the second was conducted during the paid advertisement period but before enforcement; the third was conducted during the last week of enforcement. Two of four Other Implementation states (OH, RI) and one (NY) Comparison state conducted in-program mini-surveys. These states conducted fewer than three in-program surveys; that decision was based on the distinct designs of their sTEP programs. For this evaluation, mini-surveys were used primarily to track belt use in the Full Implementation group of states.

Mini-survey sites were sampled based on accurately representing the overall statewide use rate. Most states clustered observation sites among a small number of geographically dispersed counties. The number of counties used was more or less dependent on the average number of individual observation sites within a county and whether or not the collection of sites would provide enough data for analyses. Sampling had to provide that the mini-survey could be accomplished in a few days' time.

A benefit of geographically dispersed counties was that occupants in different media markets could be observed. Sampling also considered, but to a lesser extent, representing urban and rural areas as well as racial differences across the state.

Mini-surveys, in some cases, included the collection of data associated with the observed occupant characteristics, including race, gender, type of vehicle, and if the observation was conducted in an urban or rural location.

\section{Pre/Post Telephone Survey}

Random dial telephone surveys were conducted before announcing the enforcement program to the public and after the period of enforcement ended. The pre/post surveys were conducted in all of the 18 study states. The survey instrument used was a NHTSA developed instrument, designed to measure drivers' knowledge and awareness related to seat belts, laws governing their use, and exposure to seat belt enforcement programs (questions included in the telephone survey are located in Appendix E). Survey samples were designed to represent statewide populations using no less than approximately 500 respondents with an approximate even split between males and females.

Survey sampling accounted for three situations in which the "study state" was actually less than statewide: respondents in the Texas surveys resided within the city limits of the ten largest cities; respondents in Michigan resided in the portion of the state receiving the CIOT program; respondents in Massachusetts resided in the western half of the state. In one state, Nevada, over-sampling (150 additional surveys) occurred in the northern half of that state to ensure that the northern media market, which is much smaller than Las Vegas, was adequately represented.

Respondents residing in states that fully implemented the CIOT program model were compared to the states that did not fully implement the CIOT model and the states using highly visible enforcement but without paid media.

\section{Driver Licensing Office Survey}

Seven of ten Full Implementation states conducted weekly surveys of motorists coming into Driver Licensing Offices (DL) for license services. These surveys were conducted before, during and immediately after the program publicity and enforcement. In most cases, states conducted five waves of surveying: baseline; at the end of the earned media only; at the end of paid media and before enforcement; 
middle-to-end of the enforcement period; and just after concluding enforcement. Texas and Nevada did not use DL surveys. Instead, they substituted multiple waves of telephone surveys. Only two of four Other Implementation states (OH, RI) and one Comparison state (NY) conducted waves of motorists' surveys. These states completed fewer survey waves and by different schedules that were more appropriate for their individual program timelines.

DLs were usually but not always located within or nearby to counties where mini-surveys occurred. The survey was a one-page questionnaire used to assess public knowledge and awareness, changes motorists may have made in their seat belt use behaviors, how vigorously they felt their police agencies enforce the law and the likelihood police would stop them. The survey form used in each state, by and large, was the same with only minor modifications to names of states, type of law, and names of law enforcement agencies as they appear on the questionnaire (see examples of English and Spanish version questionnaires in Appendix D).

Generally, five waves of surveying occurred over a six-week period. The one page questionnaire remained unaltered between waves to measure change as the campaign progressed. The first wave of surveys provided baseline information. DL conducted that wave over the two-week period leading up to the announcement of the enforcement program. Subsequent weekly survey waves provided information on the different stages of the program as they unfolded. DL conducted second and third waves at the end of the earned media and paid media weeks and conducted the fourth wave at the end of the second enforcement week, considered the height of program activity. The fifth wave measured program effects immediately after the enforcement period. 


\section{RESULTS}

\section{Observational Surveys of Belt Use}

Overall change in the belt use rate was measured using observational surveys. Table 3 shows results from baseline and post surveys and the amount of change between the two.

All ten Full Implementation states reported baseline and post survey results. Eight of ten reported statewide surveys measuring both the baseline use rate and the post-mobilization use rate. The two states that did not, Illinois and Washington, measured a baseline using a mini-sample survey. A comparable post-mobilization mini-sample was extracted from their post-statewide surveys to determine pre/post rate change in these two states.

Rate increases occurred in all ten Full Implementation states. Among the ten states, the average increase was 8.6 points. Vermont measured the largest increase (18.7). West Virginia also measured a large increase (15.1). These two states were among the lowest in the baseline. The state with the absolute lowest baseline, Mississippi, improved 7.7 points, just below the group average. Washington and Texas, states with the two highest baseline rates, also improved. The Texas use rate improved 5.9 points and Washington's use rate improved 8.7 points. Indiana measured the least amount of increase (3.0) followed by Illinois (3.7).

Rate increases were measured in three of four Other Implementation states. The average increase measured 2.7 points. Ohio reported statewide surveys measuring both baseline and post rates. A comparison of survey results indicated Ohio's use rate increased 6.1 points statewide. Rhode Island measured a baseline using a mini-sample survey. A comparable post-mobilization mini-sample was extracted from Rhode Island's post-statewide survey to determine rate change. The comparison indicated that Rhode Island increased 6.0 points. For Colorado and Michigan, their 2001 statewide use rate (reported to NHTSA) represented the baseline. Colorado's rate in 2001 measured 72.1 percent. A statewide survey after enforcement ended measured the use rate at 73.2, a 1.1 point increase. Michigan reported an 82.3 use rate in 2001 . Their 2002 post-program statewide rate (80.0) indicated that a 2.3 point decrease occurred.

Rate increases were measured in two of four Comparison states. The average increase for the group measured half-a-point. Among the Comparison states, only New York completed both a baseline and a post statewide survey. A comparison of these surveys indicated that a 4.5 point increase occurred by the end of the mobilization. The three other Comparison states did not have statewide survey results for estimating change. There were mini-survey results instead. Iowa showed a relatively small increase (1.6), Oregon a relatively small decrease (-0.7) and Western Massachusetts a larger decrease (-3.4).

The belt use rate improved in 15 of 18 study states. All states in the Full Implementation group increased, three of four in the Other Implementation group increased and two of four in the Comparison group increased. Improvement was greatest across Full Implementation states (8.6 points), less across Other Implementation states (2.7) and least across Comparison states (0.5). Baseline belt use rates were typically higher among primary law states, compared to secondary law states. Post program survey results indicated the same pattern. Three of four Comparison states have a primary law. Belt use across the Comparison states started higher and ended higher, compared to the other two study groups, and improved least. Among the Full Implementation group, increases occurred in states either primary or secondary and with either high or low baselines. 
Table 3. Observed Changes in the Seat Belt Use Rate by State

\begin{tabular}{|c|c|c|c|}
\hline & Baseline & Post & $\begin{array}{r}\text { Estimated } \\
\text { Change }\end{array}$ \\
\hline Full Implementation & $(\mathrm{N}=312,172)$ & $(\mathrm{N}=324,895)$ & \\
\hline$\overline{\mathrm{AL}} \quad(116,064)$ & 70.3 & 78.7 & +8.4 \\
\hline$(60,705)$ & 66.5 & 75.1 & +8.6 \\
\hline$(69,025)$ & 70.6 & 74.3 & +3.7 \\
\hline$(39,491)$ & 69.2 & 72.2 & +3.0 \\
\hline$(218,347)$ & 53.8 & 61.5 & +7.7 \\
\hline$(40,000)$ & 70.6 & 76.4 & +5.8 \\
\hline$(30,016)$ & 80.5 & 86.4 & +5.9 \\
\hline$(19,779)$ & 66.2 & 84.9 & +18.7 \\
\hline$(12,089)$ & 80.8 & 89.5 & +8.7 \\
\hline$(31,551)$ & 56.5 & 71.6 & +15.1 \\
\hline Average & 68.5 & 77.1 & +8.6 \\
\hline Other Implementation & $(\mathrm{N}=185,173)$ & $(\mathrm{N}=188,857)$ & \\
\hline $\begin{array}{ll}\mathrm{CO} & (291,450)\end{array}$ & 72.1 & 73.2 & +1.1 \\
\hline$(30,248)$ & 82.3 & 80.0 & -2.3 \\
\hline$(44,240)$ & 64.2 & 70.3 & +6.1 \\
\hline$(8,092)$ & 62.6 & 68.6 & +6.0 \\
\hline Average & 70.3 & 73.0 & +2.7 \\
\hline Comparison & $(\mathrm{N}=118,761)$ & $(\mathrm{N}=122,247)$ & \\
\hline$\overline{\mathrm{IA}}(23,898)$ & 81.4 & 83.0 & +1.6 \\
\hline$(175,328)$ & 78.3 & 82.8 & +4.5 \\
\hline$(36,115)$ & 88.5 & 87.8 & -0.7 \\
\hline West MA & 60.6 & 57.2 & -3.4 \\
\hline Average & 77.2 & 77.7 & +0.5 \\
\hline
\end{tabular}

Figure 3. Observed Changes in the Seat Belt Use Rate by Study Group

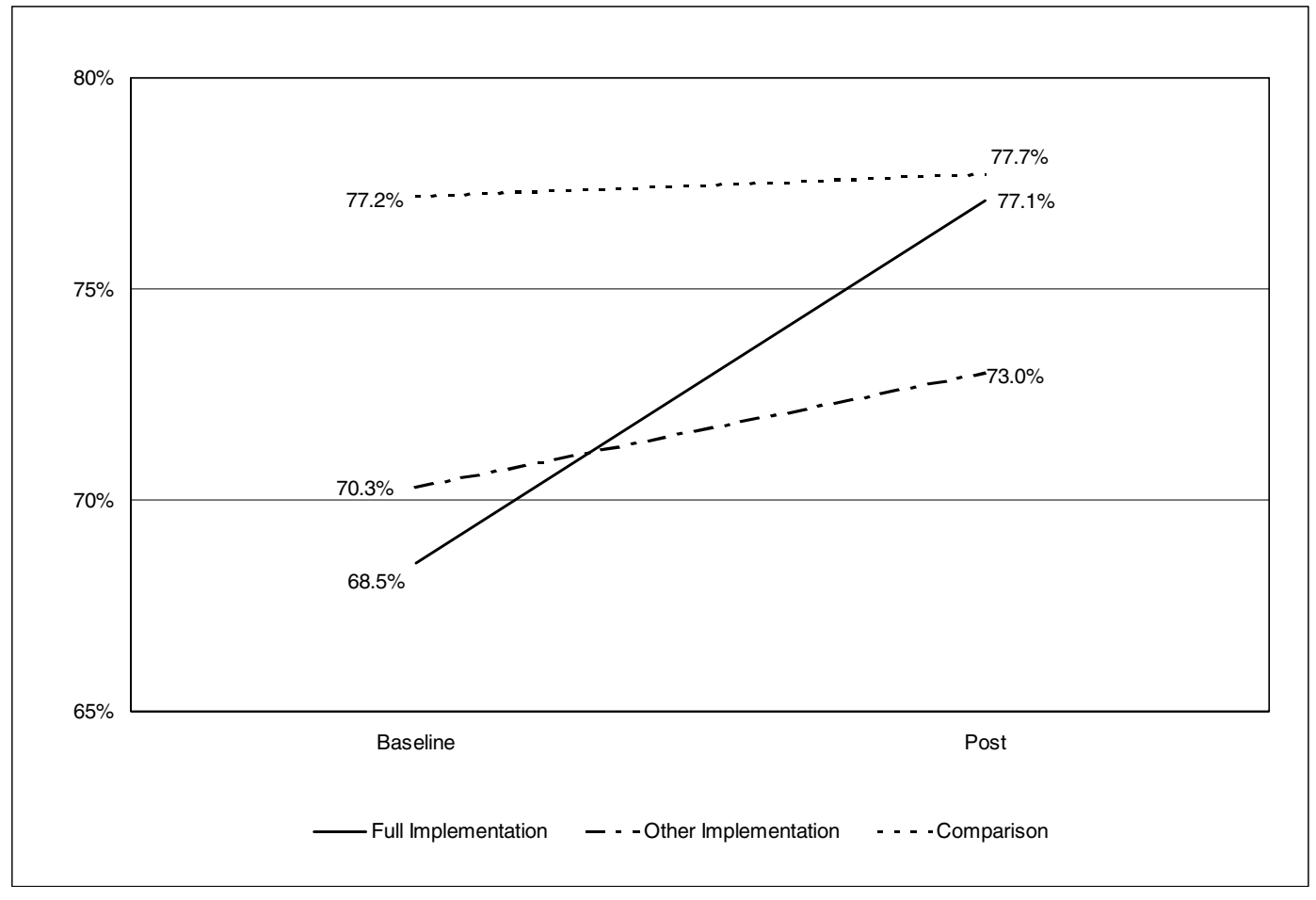


Results presented so far suggest that states with a lower baseline belt use rate improved the most. This was true in three of four Full Implementation states with lowest belt use (WV, VT, FL). Mississippi, the exception, had the lowest baseline, but still experienced nearly an eight-point increase. A similar pattern existed for Other Implementation states and was partially evident among Comparison states. On the other end of the spectrum, baseline measurements indicated two Full Implementation states (WA, TX) in the $80^{\text {th }}$ percentile range, along with one Other Implementation state (MI) and two Comparison states (IA, OR). Post observational surveys indicated larger rate increases in the two Full Implementation states, Washington and Texas (8.7 and 5.9 points, respectively), compared to Iowa (1.6); Oregon (-0.7); and Michigan (-2.3). These results suggest that full implementation of CIOT can improve a belt use rate, whether the starting baseline use rate is high or low.

\section{Mini-Sample Surveys of Belt Use}

Full Implementation states reported not only baseline and post survey results, but also results from in-program measurements of the belt use rate. The graph in Figure 4 shows changes in the use rate over time for each of these states ${ }^{4}$. The belt use rate increased modestly during the publicity period before the enforcement period. Only after enforcement began did the large increases occur. The timing of that change was evident in every state, suggesting that most improvement in the belt use rate does not appear until the actual enforcement appears.

Increases in the belt use rate from occupant protection sTEP programs typically diminish, soon after ending stepped up enforcement. As such, post surveys tend to display decreasing or diminishing rates. That was not the case among the Full Implementation group where the rate maintained current or slightly higher levels. This may be due to the fact that post observational surveys were done within a week or two after ending program enforcement and media.

Figure 4. Observational Surveys of Belt Use; Mini-Survey Belt Use Rate $(\mathrm{N}=464,589)$

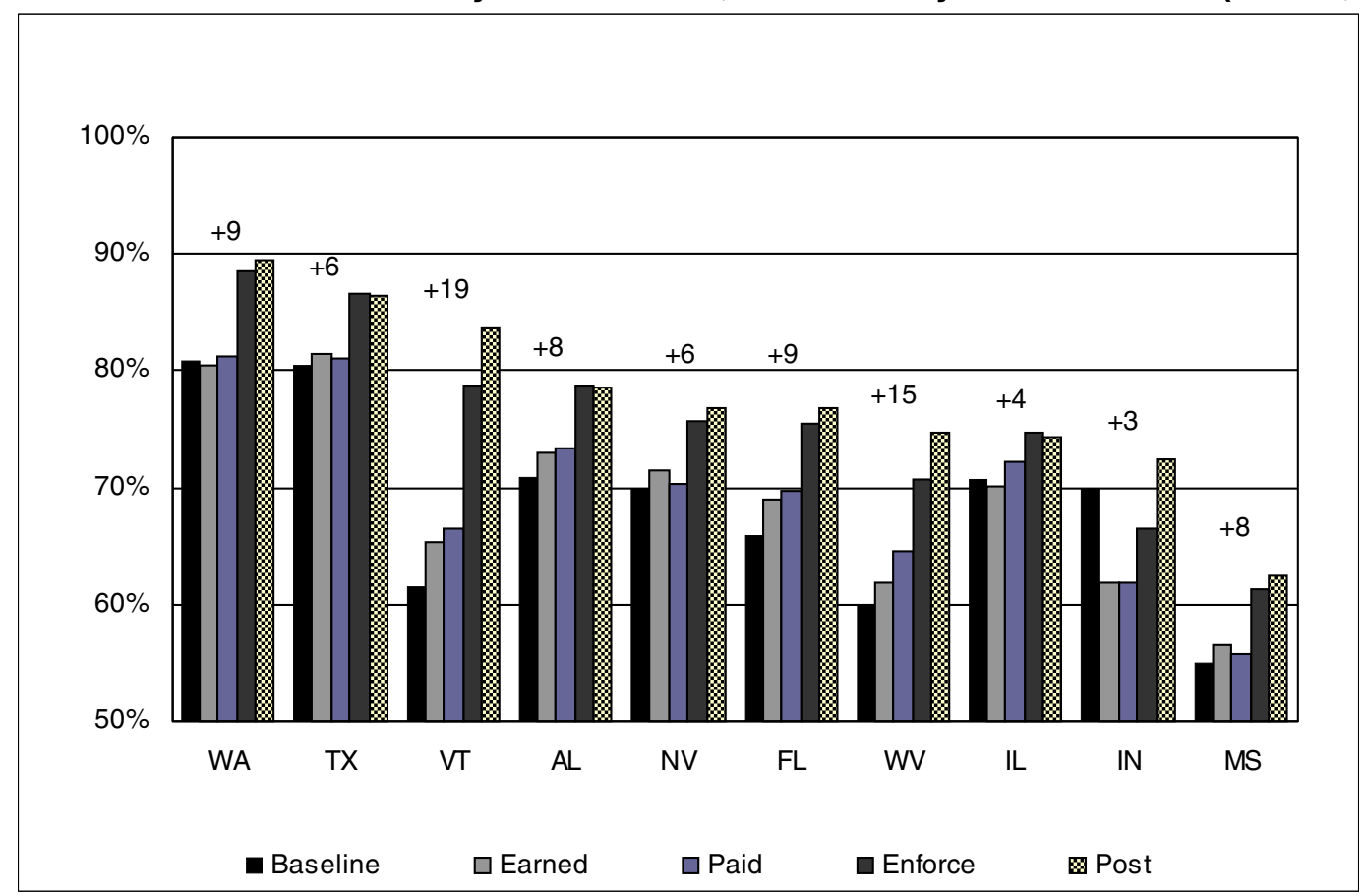

\footnotetext{
${ }^{4}$ In addition to the Full Implementation states, New York, Ohio and Rhode Island conducted in-program minisurveys; results are not shown in the graph.
} 


\section{Pre/Post Telephone Survey}

The telephone survey included a total of 18,328 respondents. Generally, there were 500 respondents per wave per state with the exception of Nevada, to which an additional 150 residents in the northern half of the state were surveyed to provide for equal representation with Las Vegas.

The figures that follow show results for selected questions from the baseline and post telephone surveys. Two figures are provided per question. The first figure contains a bar graph showing baseline and post results per state, in which baseline results are represented by light-gray segments and increases measured by the post-survey are represented by dark-gray segments. The second figure contains a line graph showing baseline and post results by study group. Baseline and post results shown in the line graphs are the calculated means across all states in the study group.

The telephone survey included questions asking respondents about recent exposure to seat belt messages and messages concerning seat belt enforcement. Respondents who indicated exposure to messages were asked to identify sources of those messages.

Respondents were asked if in the past 30 days had they seen or heard any messages encouraging seat belt use (Figures 5 and 6). In the baseline survey, 72 percent of respondents in Full and Other Implementation groups and 66 percent in Comparison group indicated that they had seen or heard messages encouraging seat belt use, suggesting that belt messages are generally commonplace. Post survey results showed a modest increase in affirmative responses with the largest increases taking place in the Full Implementation group. Increases in the Other Implementation group of states were not as large as the Full Implementation group of states but were larger than that of the Comparison Group. Post survey results indicated that exposure to a seat belt message ranged from 79 to 91 percent in the Full Implementation group, 76 to 85 percent in the Other Implementation group, and 69 to 75 percent in the Comparison group.

Respondents indicated whether or not they had seen or heard messages concerning seat belt enforcement in the past 30 days (Figures 7 and 8). Baseline results indicated that respondents generally had some exposure to a seat belt enforcement message, but most had not. Post survey respondents indicated an increase in awareness and the increase was evident in every state. A comparison of the study groups indicated that the Full Implementation group increased much more sharply compared to the Other Implementation group, and even more sharply compared to the Comparison group.

Post survey results indicated that exposure to messages concerning seat belt enforcement ranged from 47 to 75 percent in the Full Implementation group, 28 to 38 percent in the Other Implementation group and 14 to 30 percent in the Comparison group. After CIOT, greater than half of the respondents in the Full Implementation group (59.1 percent) indicated they had seen or heard about special police efforts towards seat belts, compared to roughly a third (34) of respondents in the Other Implementation group, and only a quarter (24.8) in the Comparison group.

Respondents who indicated they had heard a seat belt enforcement message in the past 30 days were also asked where they had seen or heard that message. Both baseline and post surveys identified television as the most common source of messages (Figures 9 and 10). Post survey results indicated that the proportion of respondents seeing a belt enforcement message on television increased in every state. Generally, increases were largest for states in the Full Implementation group. Large increases also were evident in some Other Implementation and Comparison states.

Baseline surveys generally indicated a low to moderate level of radio exposure in the study states (Figures 11 and 12). Post survey respondents indicated increases in exposure in every state. Amount of 
increase was relatively equal across the three study groups. Colorado and Rhode Island were the only states to show larger increases in radio exposure, compared to increases in television exposure (from pre to post). These two states relied on paid radio advertisements, not television, to get the message out to the public. enforcement.

The telephone survey asked respondents a number of questions concerning perceived seat belt

Regarding perceived enforcement, respondents were asked if they agree that police in the community are writing more tickets now than a few months ago (Figures 13 and 14). Baseline results indicated a moderately low proportion (12 to 18 percent) of respondents who "strongly agree." The proportion of post survey respondents who "strongly agree" increased in all three of the study groups. A much sharper increase occurred in the Full Implementation states, compared to the other two study groups.

Post survey respondents who "strongly agree" ranged from 27 to 55 percent among states in the Full Implementation group, 16 to 25 percent among Other Implementation states and 13 to 23 percent among Comparison states. After CIOT, nearly 40 percent of respondents in the Full Implementation group indicated they "strongly agree" that police were issuing more tickets, nearly double the percent across the Other Implementation group (20) and the Comparison group (19).

Respondents were also asked how likely they think the chances are to receive a ticket for not wearing a seat belt (Figures 15 and 16). Post survey results found the proportion of respondents who perceived a ticket "very likely" increased in almost every state. All states in the Full Implementation group increased, three of four in the Other Implementation group increased and three of four in the Comparison group increased. The Full Implementation group increased more sharply, compared to the two other study groups.

Most states with a standard enforcement seat belt law (AL, IN, TX) stand out in Figure 15. Typically a greater proportion of respondents in these states reported non-user chances of a ticket "very likely," compared to secondary law states. This held true regardless of study group. That pattern was evident in both the baseline and the post survey results.

Survey respondents were asked to identify media message slogans they may have seen or heard (Figures 17 and 18). The Click It or Ticket slogan was widely recognized with major increases being seen in the Full Implementation states and less but still impressive increases in the Other Implementation states. In several states (Alabama, Indiana, Michigan and Mississippi), slogan recognition was around the 50 percent level in the baseline survey, indicating that there had been retention of the Click It or Ticket slogan from earlier campaigns.

Nevada and Ohio did not use the "Click It or Ticket" slogan in paid advertisements. Nevada used "No Excuses, No Exceptions, Buckle Up" and Ohio used "What's Holding You Back." Recognition of these slogans did not reach the level of recognition found in most paid media states. Colorado and Rhode Island, the two states spending least and focusing solely on radio, received comparatively less slogan recognition. Among the Comparison group, only New York used the "Click It or Ticket" slogan, Iowa used "Show a Little Restraint," Oregon used "Life is Good - The Way to Go" and western Massachusetts used "Buckle Up Massachusetts." Respondents in the Comparison group were less likely to identify the principal program slogan compared to respondents in paid media group of states. 
Figure 5. Past 30 Days, Saw or Heard Messages Encouraging Seat Belt Use by State

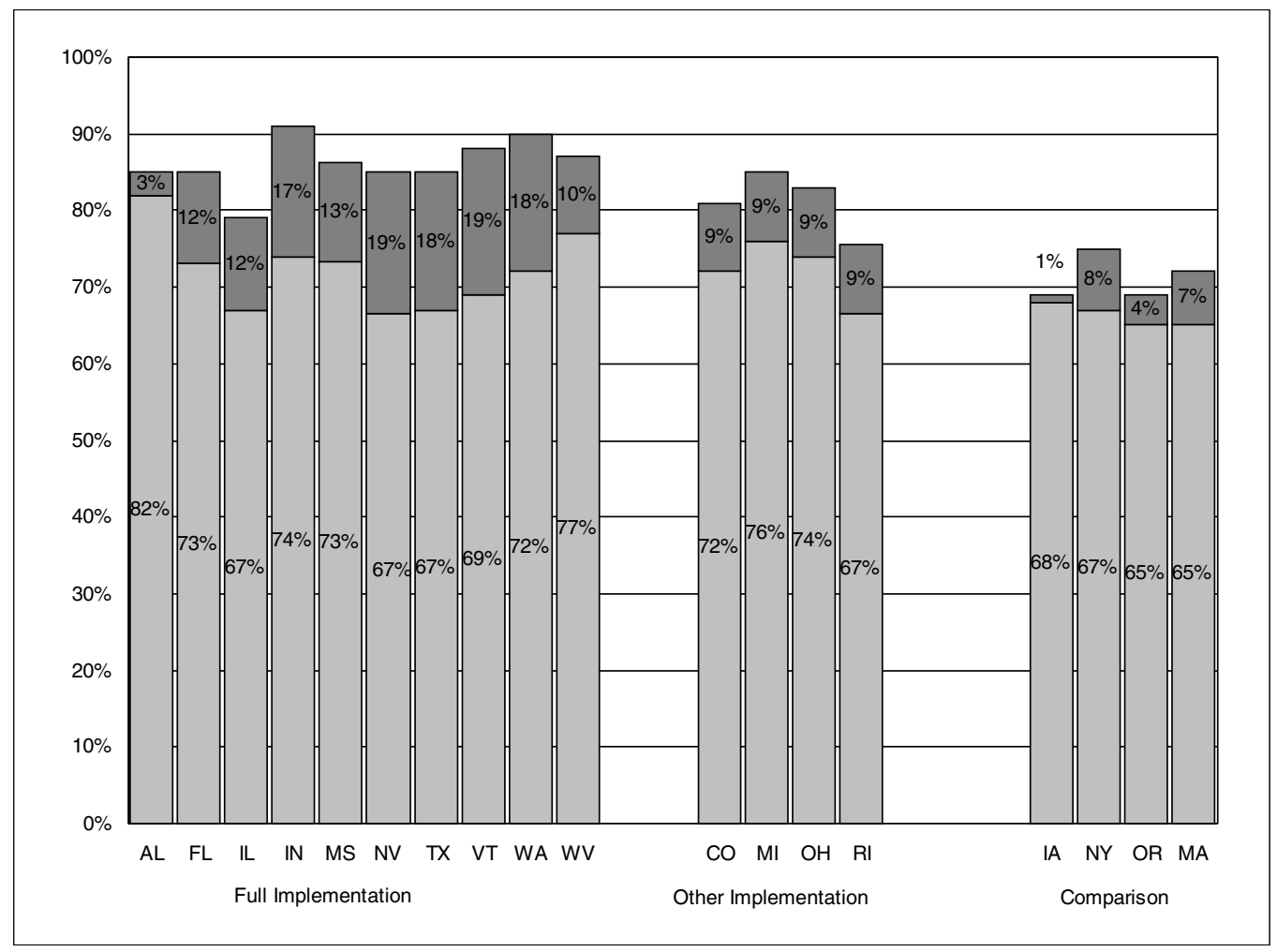

Figure 6. Past 30 Days, Saw or Heard Messages Encouraging Seat Belt Use by Study Group

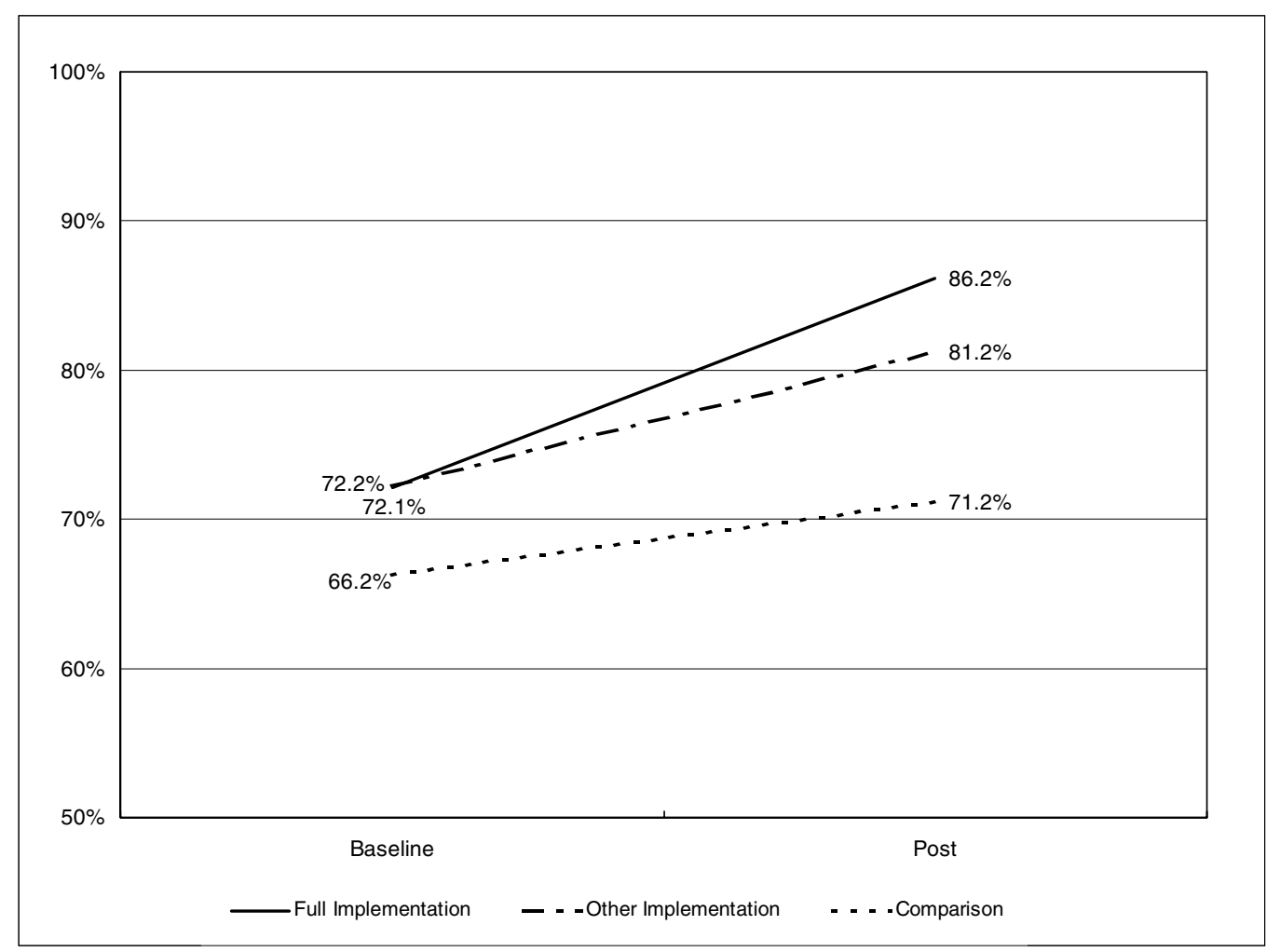


Figure 7. Past 30 Days, Saw/Heard of Special Police Efforts towards Belts by State

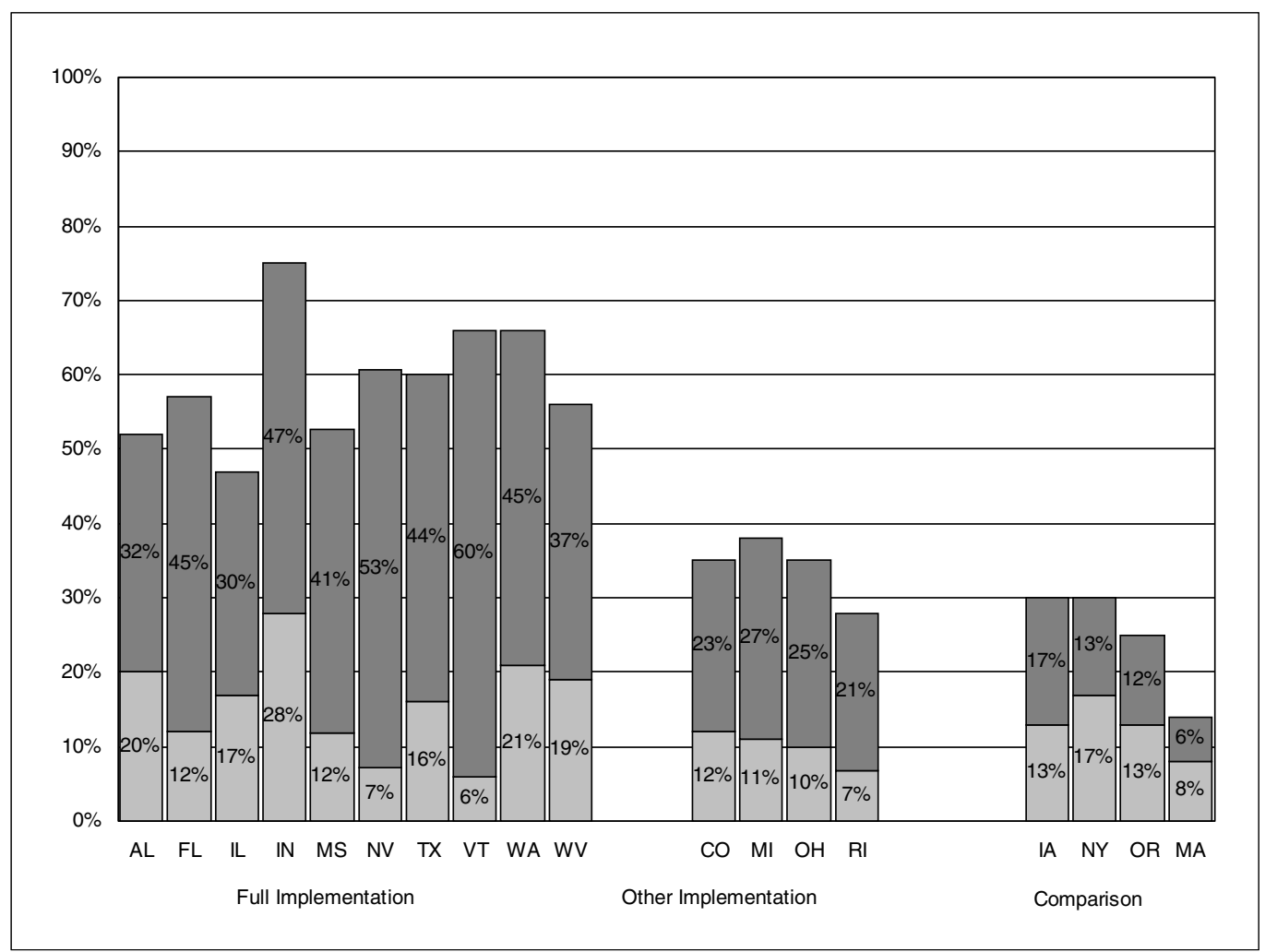

Figure 8. Past 30 Days, Saw/Heard of Special Police Efforts towards Belts by Study Group

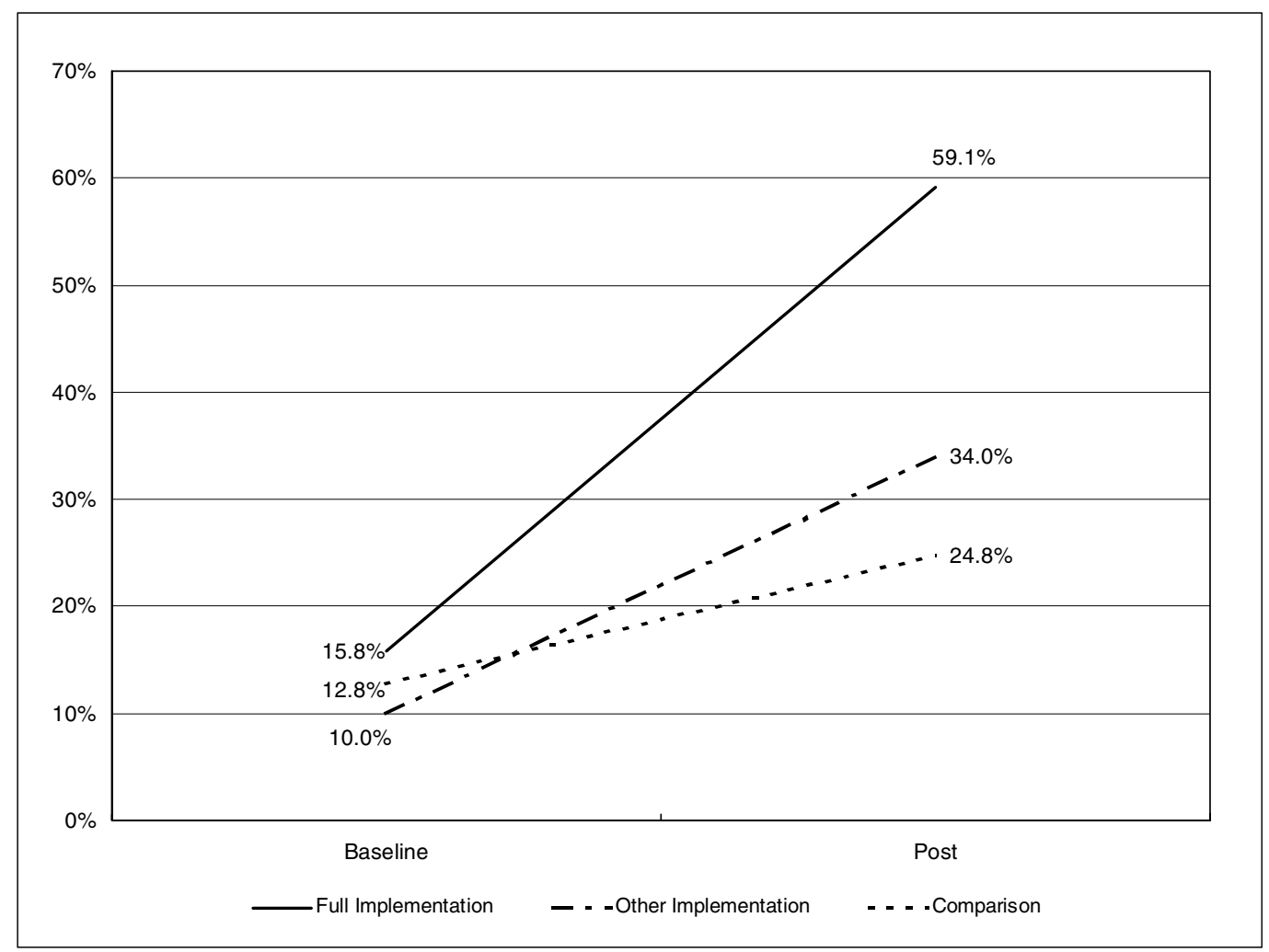


Figure 9. Past 30 Days, Saw of Special Ticketing Effort on Television by State (subset of total respondents)

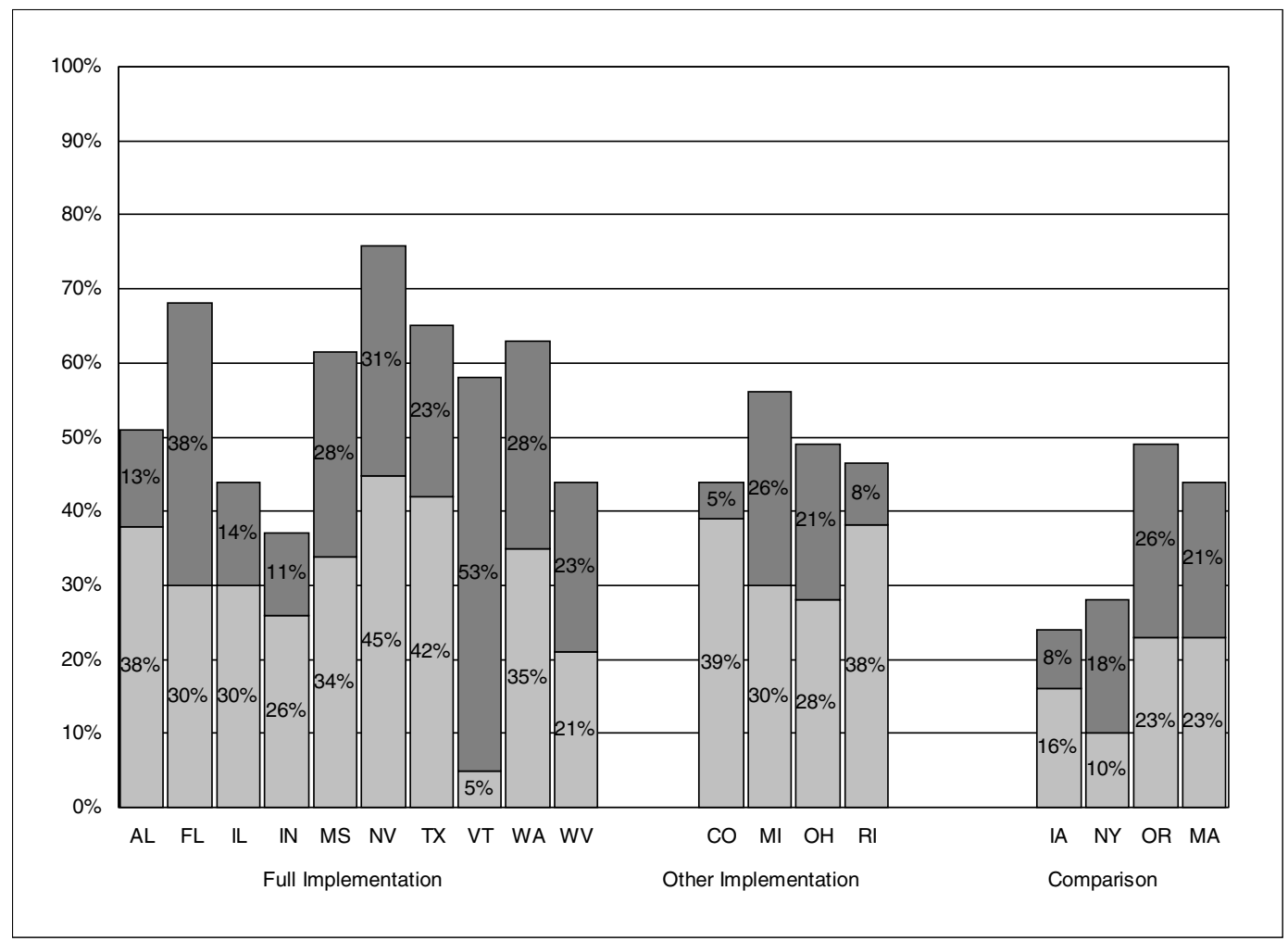

Figure 10. Past 30 Days, Saw of Special Ticketing Effort on Television by Study Group (subset of total respondents)

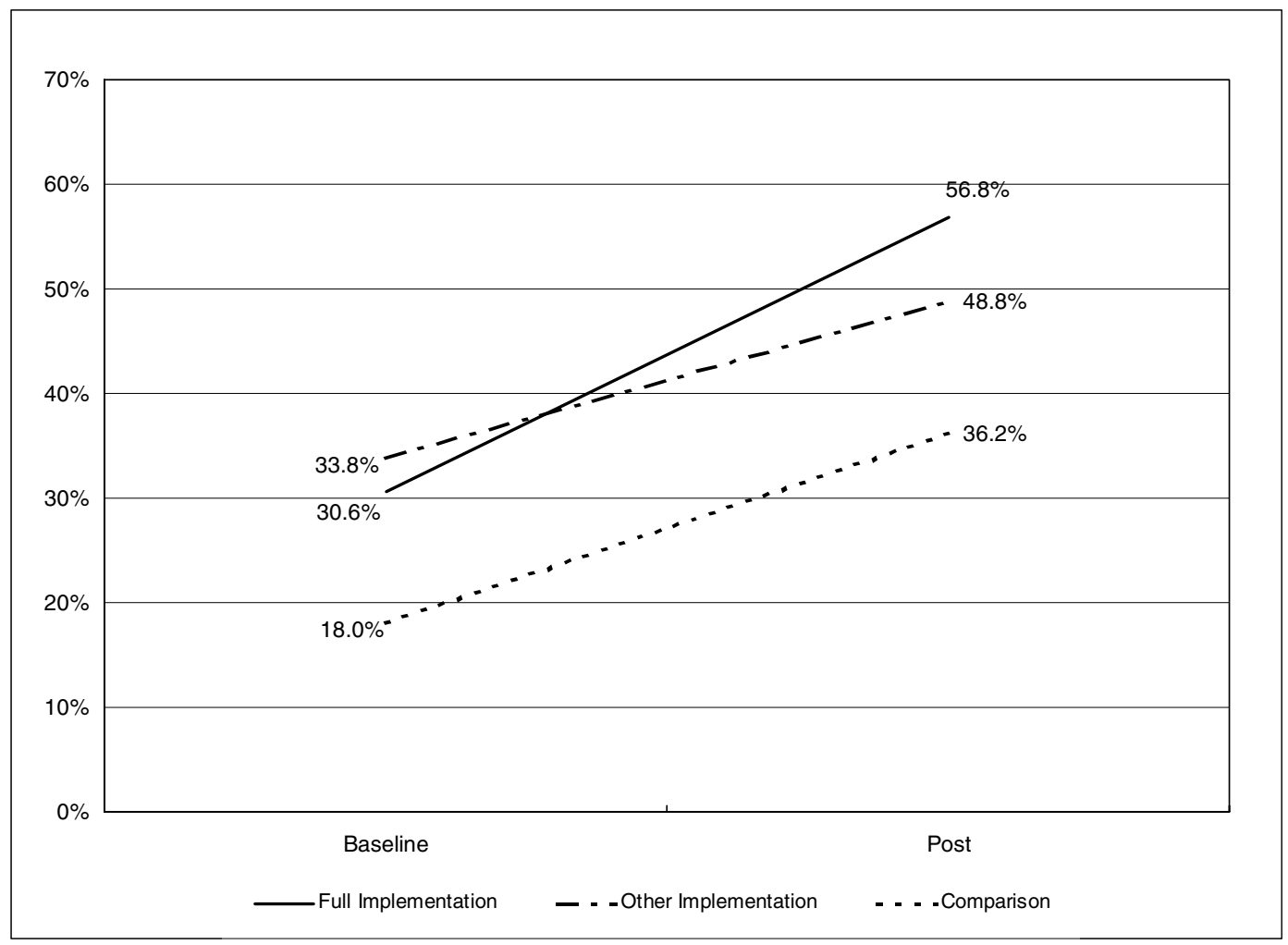


Figure 11. Heard of Special Ticketing Effort on Radio by State (subset of total respondents)

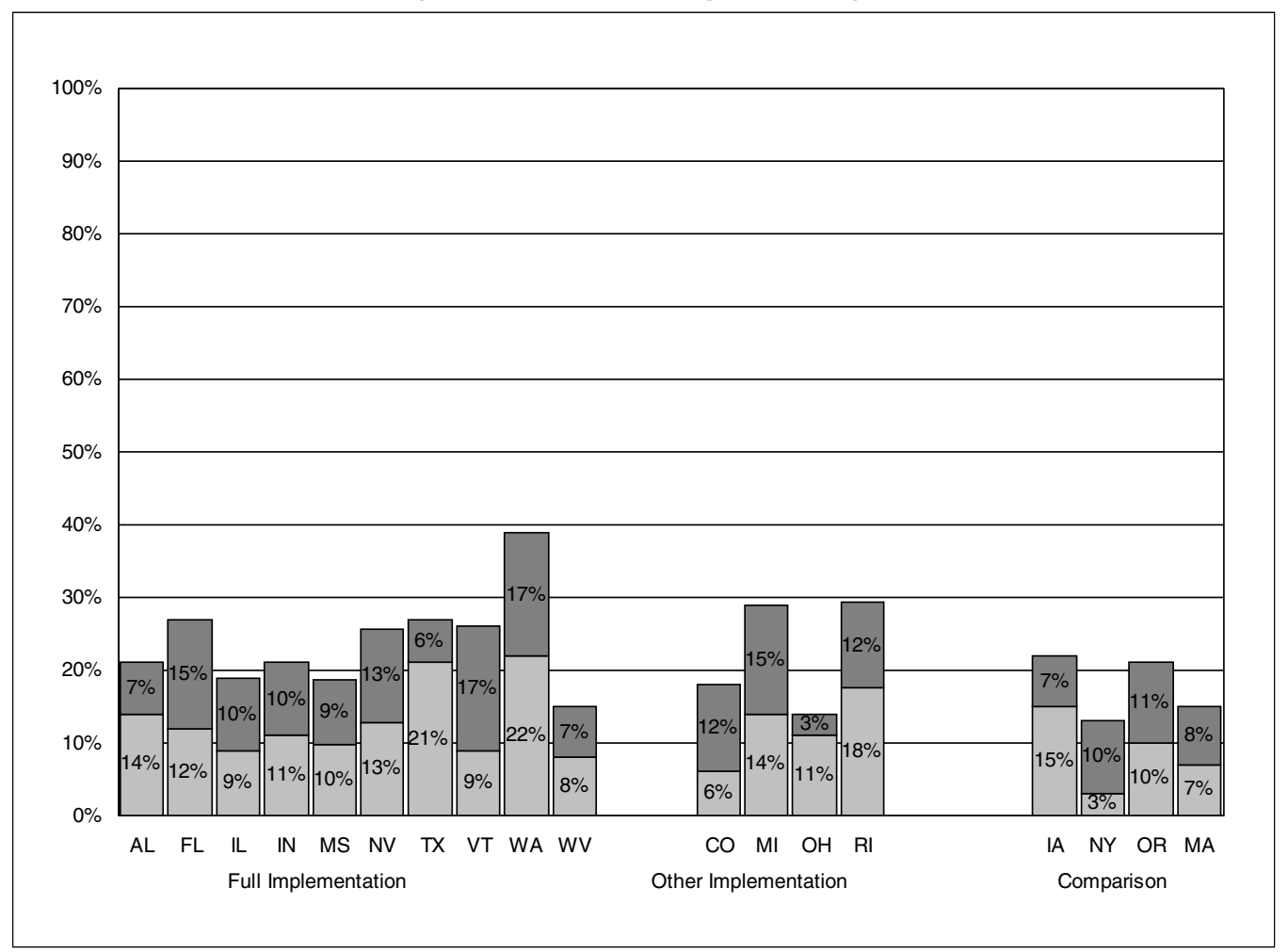

Figure 12. Past 30 Days, Heard of Special Ticketing Effort on Radio by Study Group (subset of total respondents)

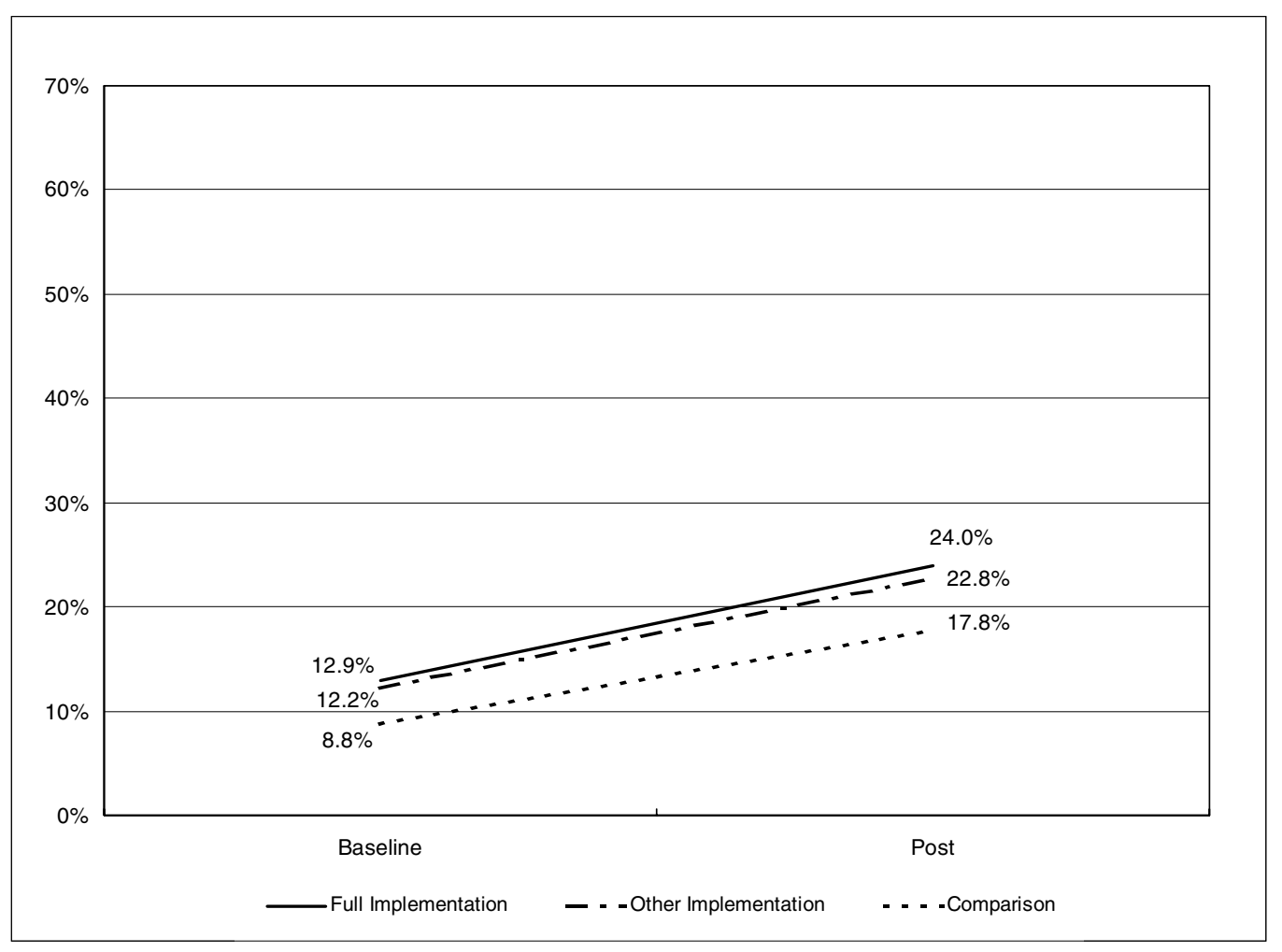


Figure 13. "Strongly Agree" Police in Community are Writing More Tickets Now by State

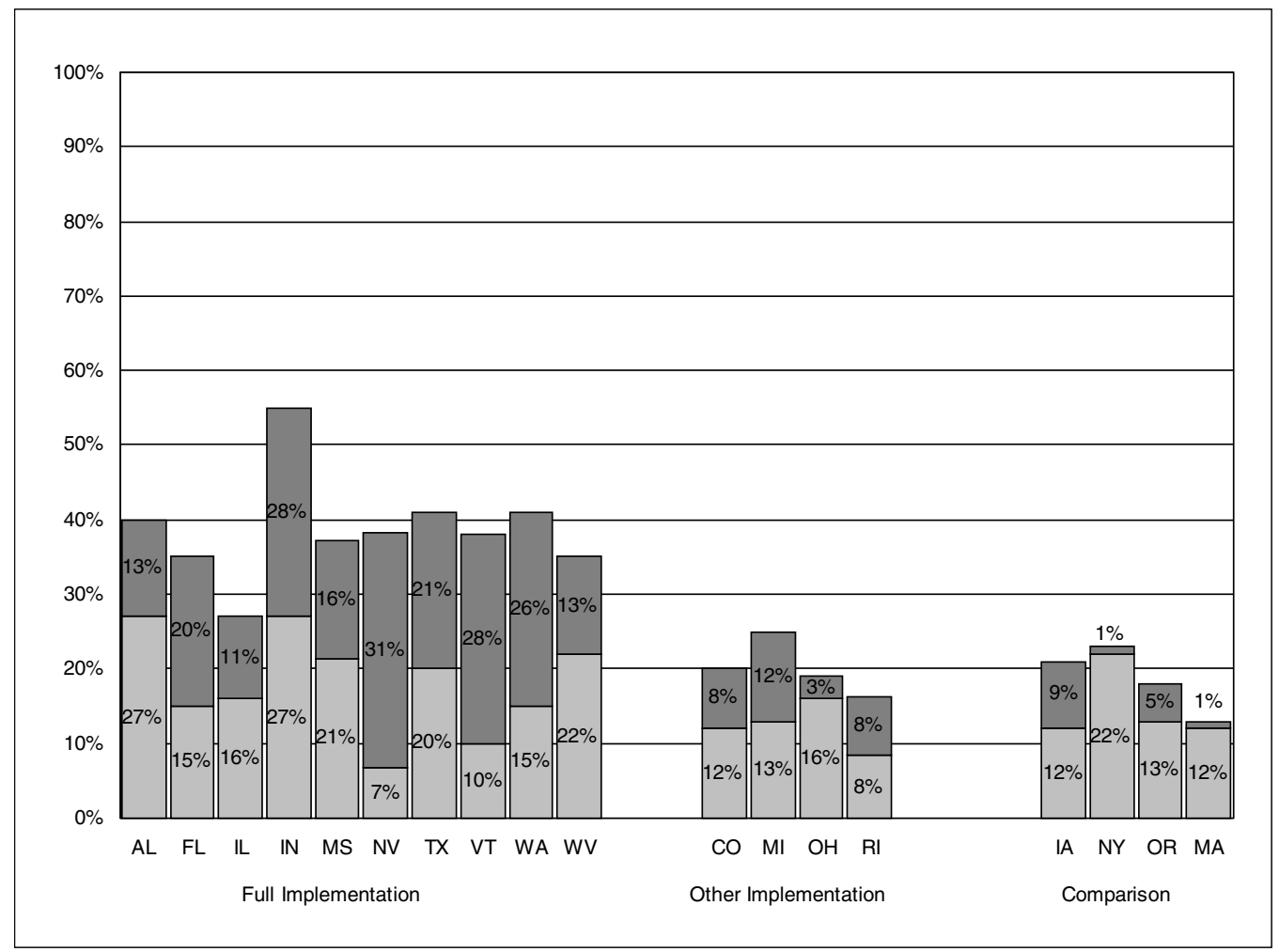

Figure 14. "Strongly Agree" Police in Community are Writing More Tickets Now by Study Group

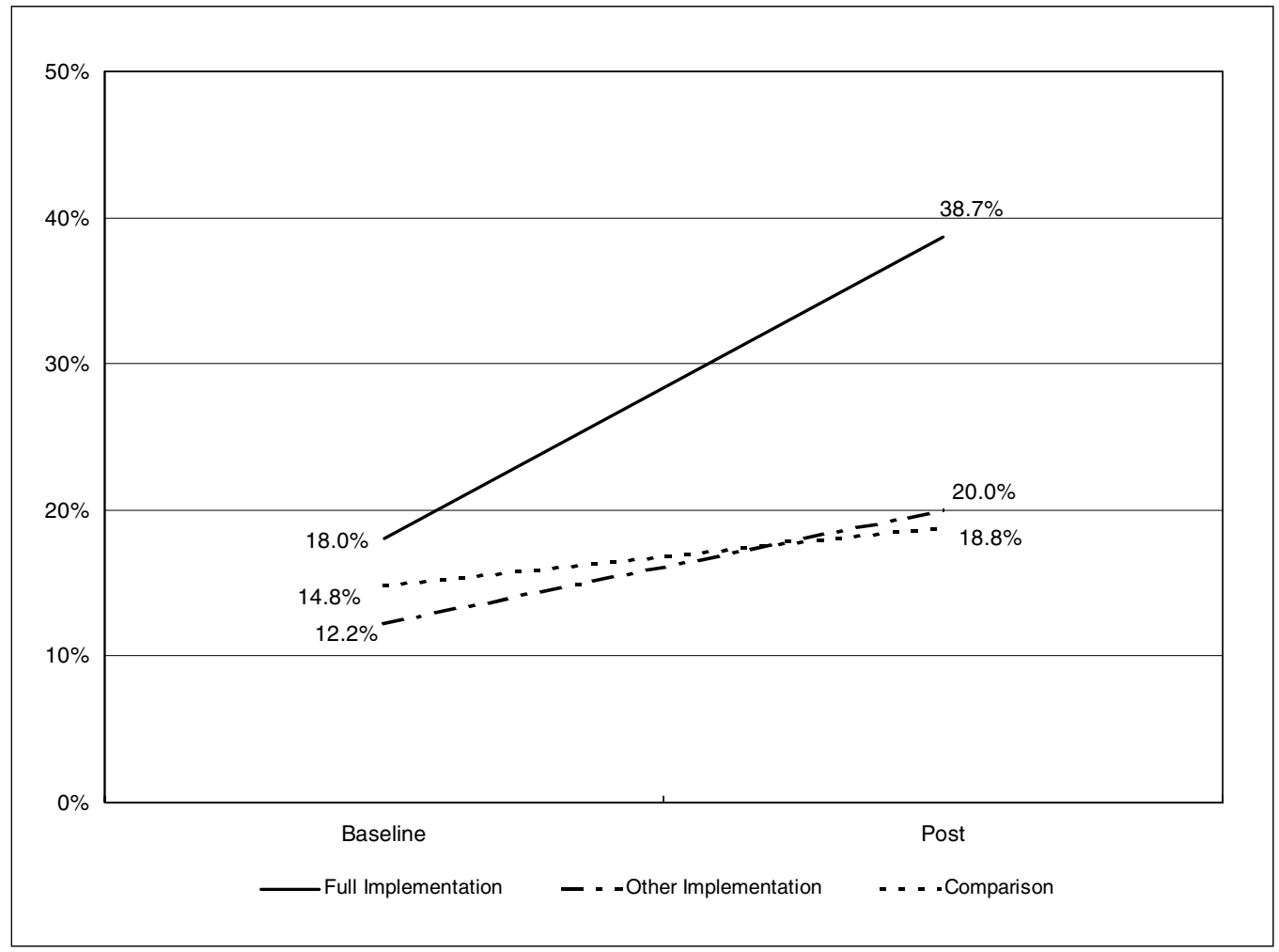


Figure 15. Reports That Over Past Six Months Ticket for Non-Use was “Very Likely” by State

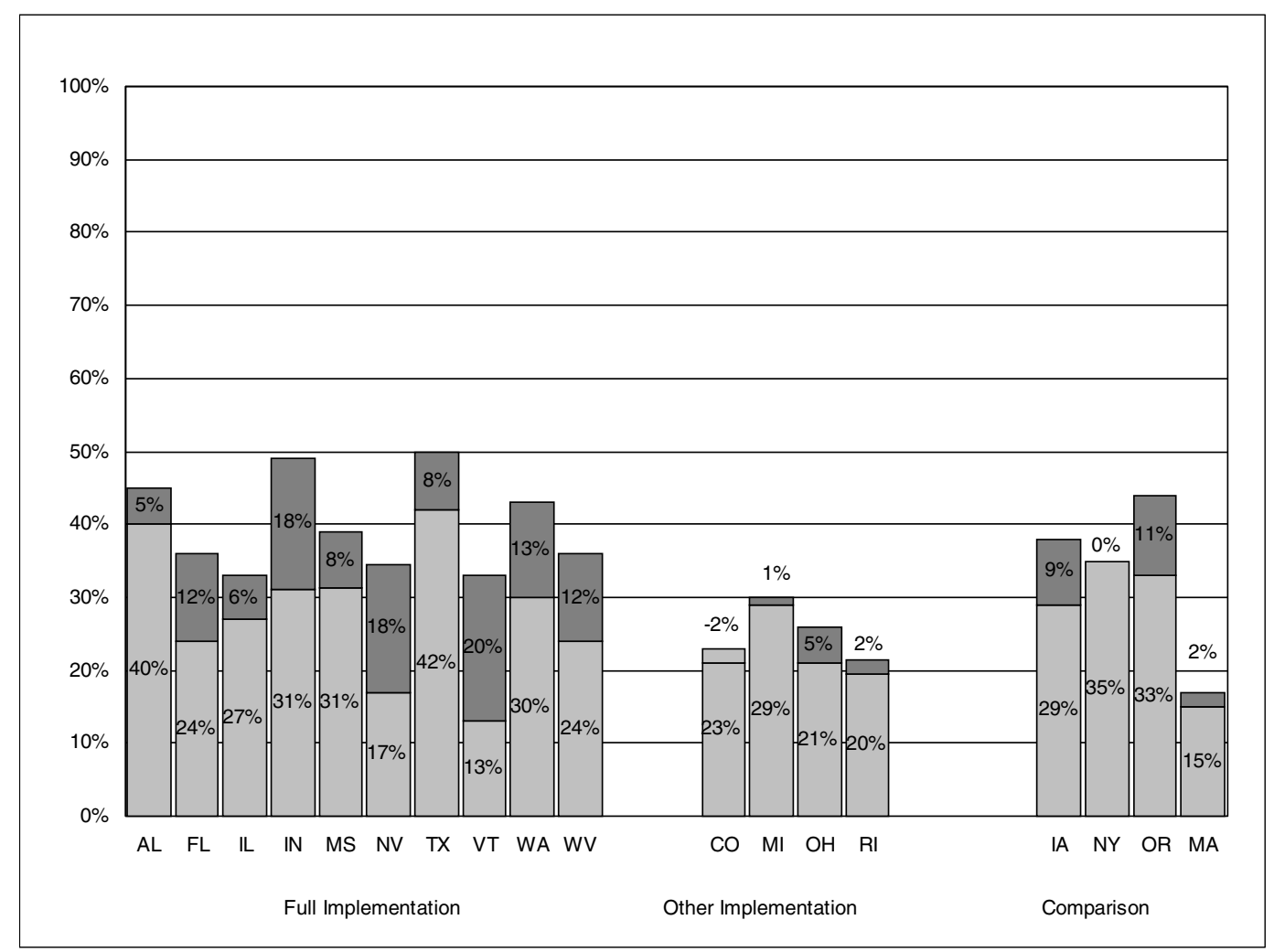

Figure 16. Reports Over Past Six Months Ticket for Non-Use was “Very Likely” by Study Group

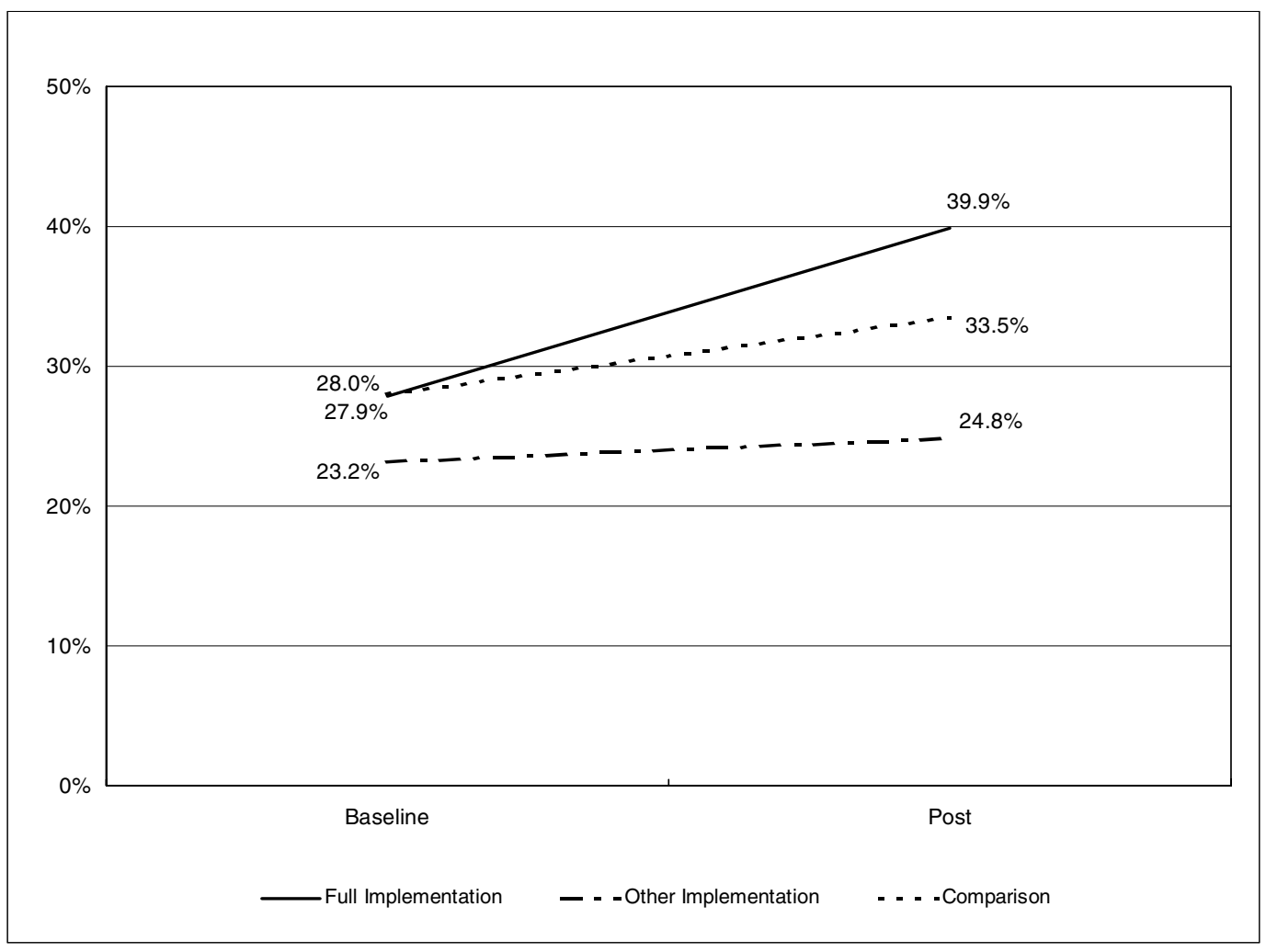


Figure 17. Recognized Principal Program Slogan by State

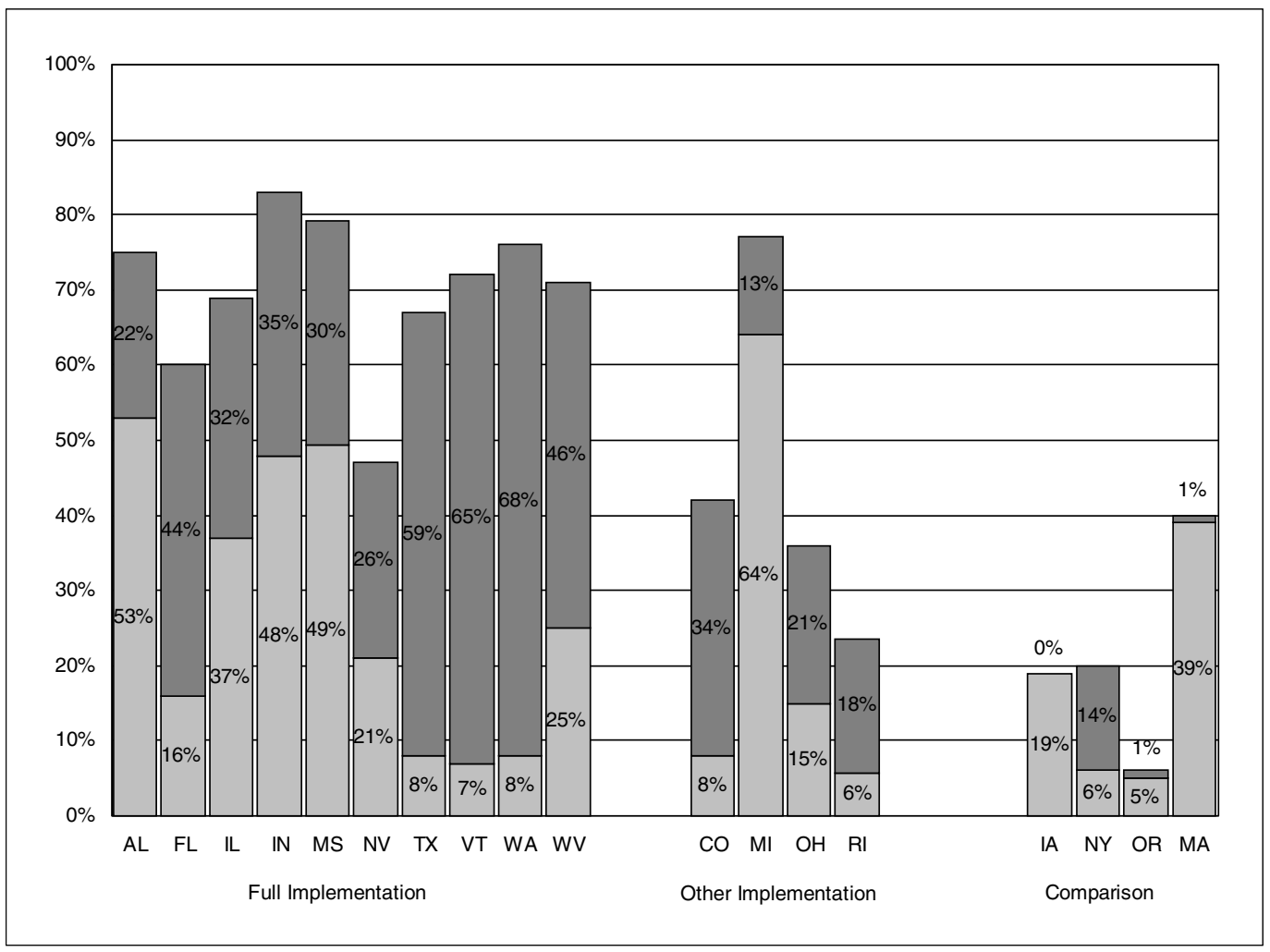

Figure 18. Recognized Principal Program Slogan by Study Group

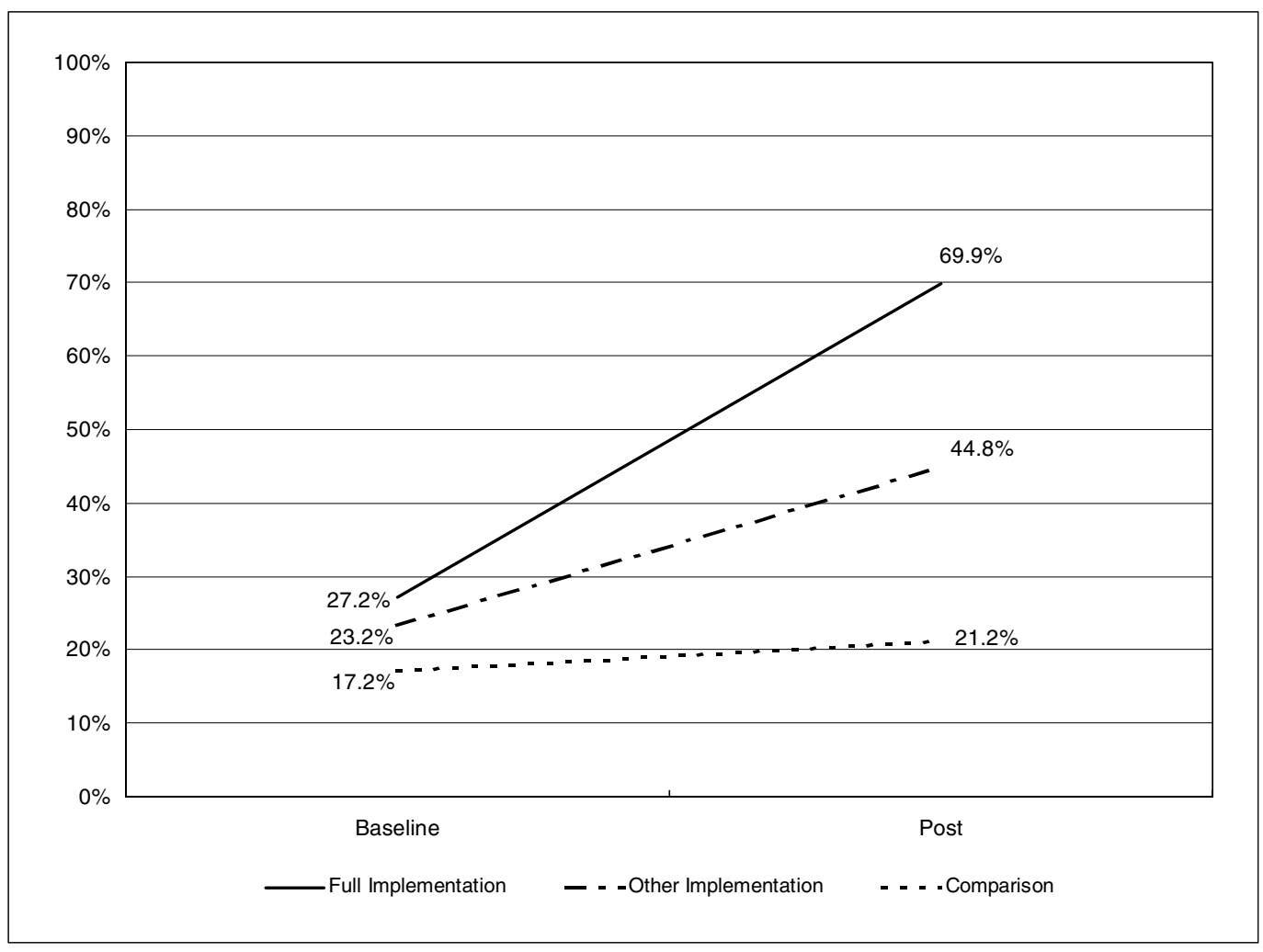




\section{Driver License Office Survey}

Surveys of licensed drivers were collected in seven of the ten Full Implementation states $(\mathrm{N}=44,319)$. Driver survey data were collected in five waves. The first wave was conducted the week preceding any program publicity, and serves as the baseline. Subsequent "weekly" survey waves started one week into the program and continued throughout the media and enforcement campaign. These weekly waves were timed to capture results towards the end of various program stages: earned media only; paid publicity; publicity and enforcement; post publicity and enforcement. Tracking driver knowledge and awareness in intervals provided information as to if and when changes in the resident driver population occurred.

The driver survey included questions about exposure to messages concerning seat belts and seat belt enforcement. Questions also asked respondents what sources of information they encountered.

Respondents were asked if they had recently seen or heard a seat belt message (Figure 19). Survey results indicated that new seat belt messages reached the public. The proportion of respondents indicating they had been exposed to a belt message increased each subsequent survey wave. Large increases tended to appear during the time of paid publicity, continuing through enforcement. Exposure measured above 80 percent in five of seven states by the end of CIOT.

The driver survey also asked respondents the more specific question, have they recently seen or heard a message concerning seat belt enforcement (Figure 20). Baseline results found that less than half of the respondents in the states indicated they had. Towards the end of the enforcement period, more than half of the respondents in all but one state (IL), acknowledged they had. Greater than 70 percent of respondents in Florida, Indiana and Washington acknowledged they had.

Respondents were also asked to identify sources of seat belt information they had encountered (Figures 21,22,23). Respondents identified television as the prime conduit before and after CIOT. Respondents also identified radio as a prevalent source, but not to the extent of television. Respondents identified the newspaper, but to an even lesser extent than radio.

Reported exposure to seat belt enforcement messages by television, radio and newspaper, increased in every state. Over time, increases were larger for television and radio compared to newspaper. Reported exposure to television messages increased most after the paid advertisements were begun. The same held true regarding radio exposure with one exception, Washington, where respondents indicated a large increase during the earned media period. Larger increases in exposure to newspaper occurred only after enforcement began.

The driver survey also included questions regarding perceived enforcement and if a personal experience occurred involving seat belt enforcement.

Respondents were asked to indicate how strictly they think their State Police and local police enforce the seat belt law (Figures 24,25). The proportion of respondents who reported "very strict" increased over the course of CIOT. Increases were indicated in every state, though they were relatively small. Amount of increase was generally equal whether the respondent was considering State Police or local police.

Respondents perceived State Police as more strict when it comes to seat belt law enforcement. A larger proportion of respondents indicated State Police as "very strict," compared to local police, and that was true in every state and evident in every survey wave. 
Two survey questions asked respondents if they had had a personal encounter involving seat belt enforcement. The first question asked respondents if they have experienced enforcement focused on seat belts in the past month. The second question asked respondents if they have ever received a ticket for not using a seat belt.

Large increases occurred in the proportion of respondents who had experienced seat belt enforcement (Figure 26). That was true in every state. Indiana stands out in the graph where over 40 percent of respondents indicated experiencing belt enforcement. This state conducted nearly 4,100 enforcement zones focusing on seat belt use.

In regards to having received a ticket for not using a seat belt, a relatively low number of respondents indicated they had (Figure 27). That did not change over time except in one state, Florida, where a small but noticeable increase was measured. Respondents in Indiana and Florida were most likely to indicate they had received a ticket sometime in the past.

Baseline surveys indicated a wide range in the proportion of respondents who indicated they had heard of "Click It or Ticket" (Figure 28). Alabama and Indiana, two states that conducted previous CIOT campaigns, had higher than average baselines. Florida, another state with prior CIOT program experience, appeared unusually low, and Illinois and West Virginia, first timers with CIOT, appeared unusually high. Few respondents in Vermont and Washington indicated they had heard of CIOT. The proportion indicating they had heard of CIOT increased, over time, in every state. Over 60 percent of respondents in all states indicated they had heard of CIOT by the end of the program, over 70 percent in Alabama and West Virginia, and over 80 percent in Indiana.

Figure 19. Saw or Heard a Seat Belt Message

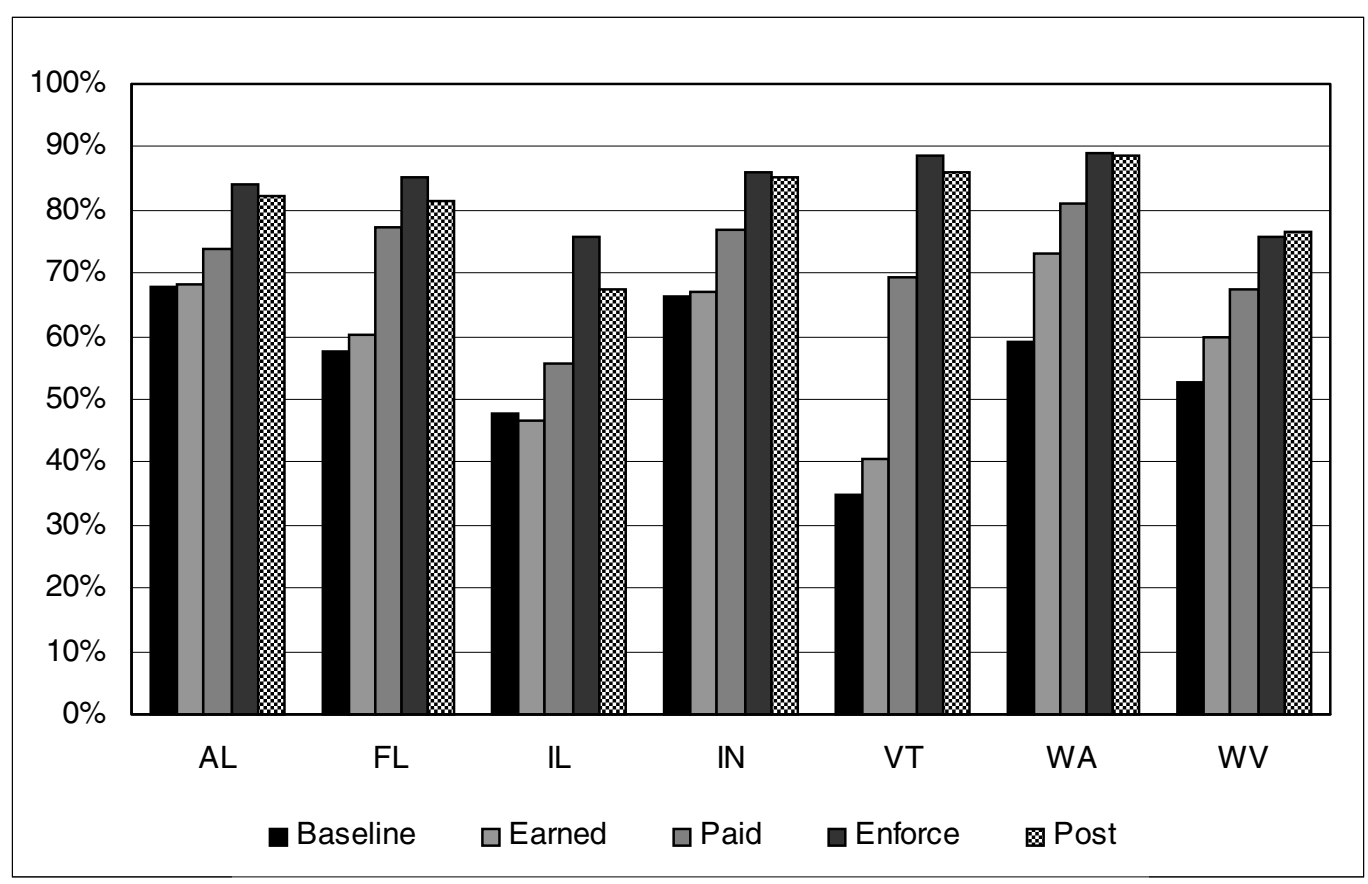


Figure 20. Saw or Heard a Seat Belt Enforcement Message

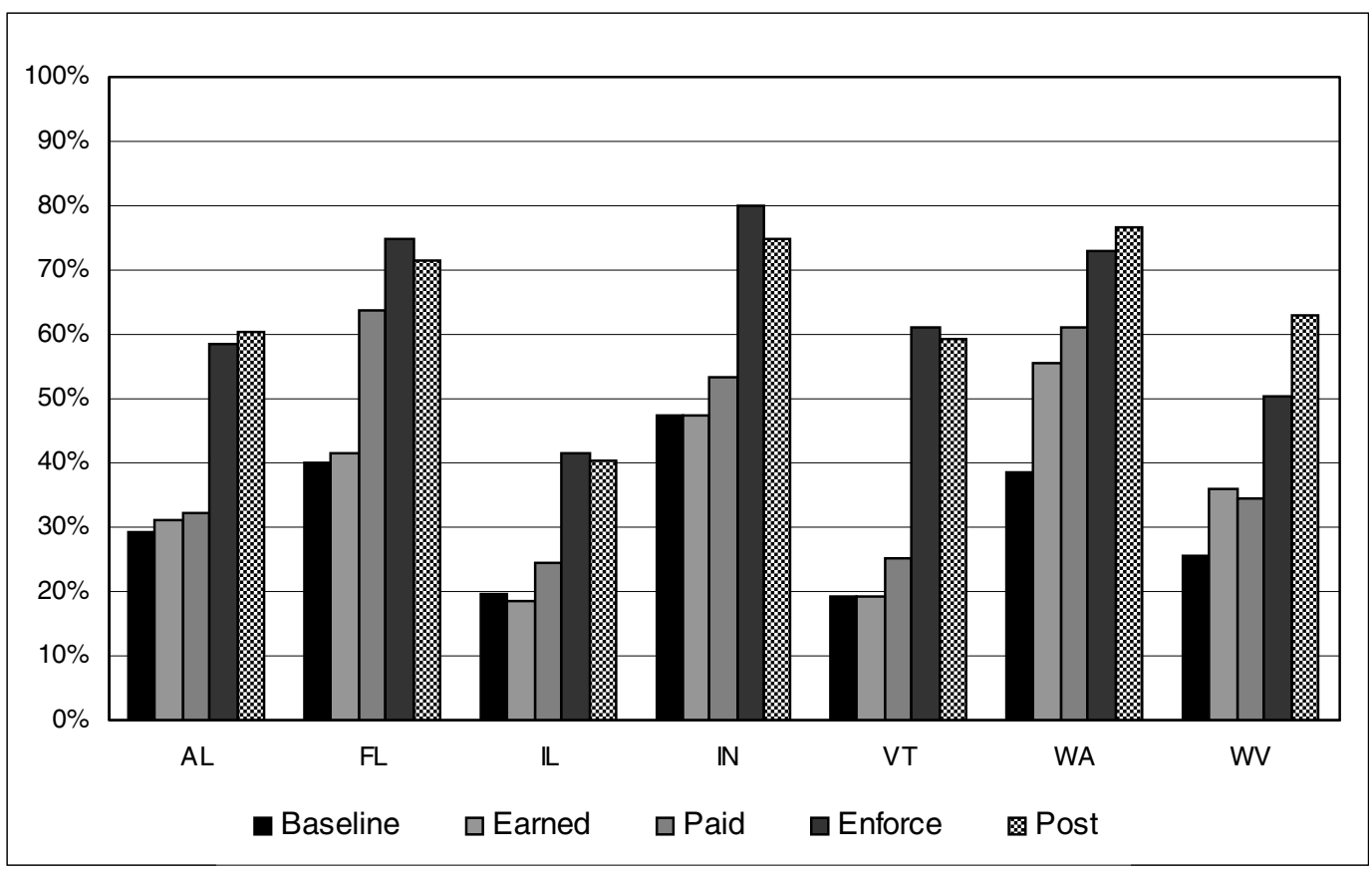

Figure 21. Saw about Seat Belts on Television

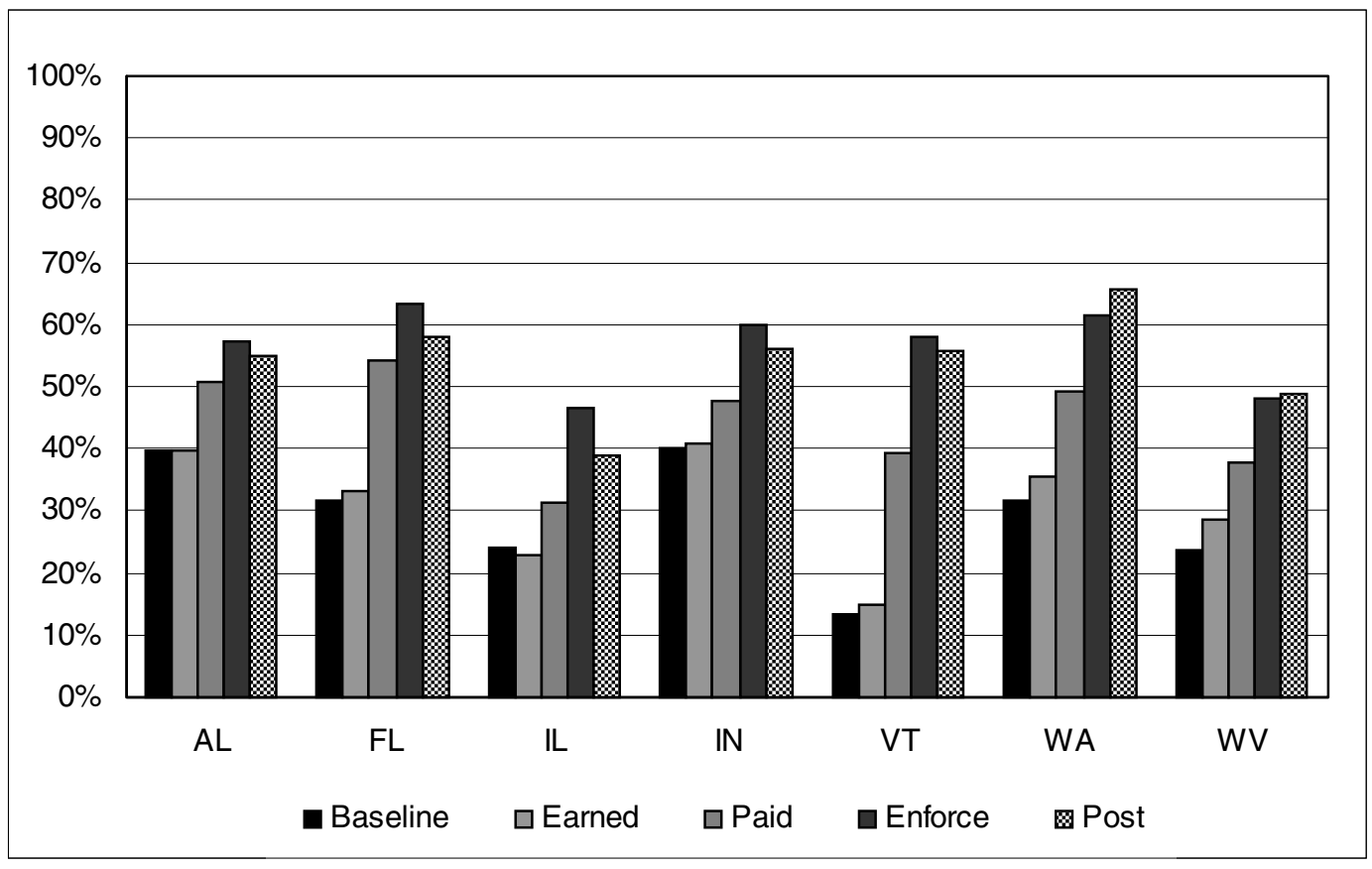


Figure 22. Heard about Seat Belts on Radio

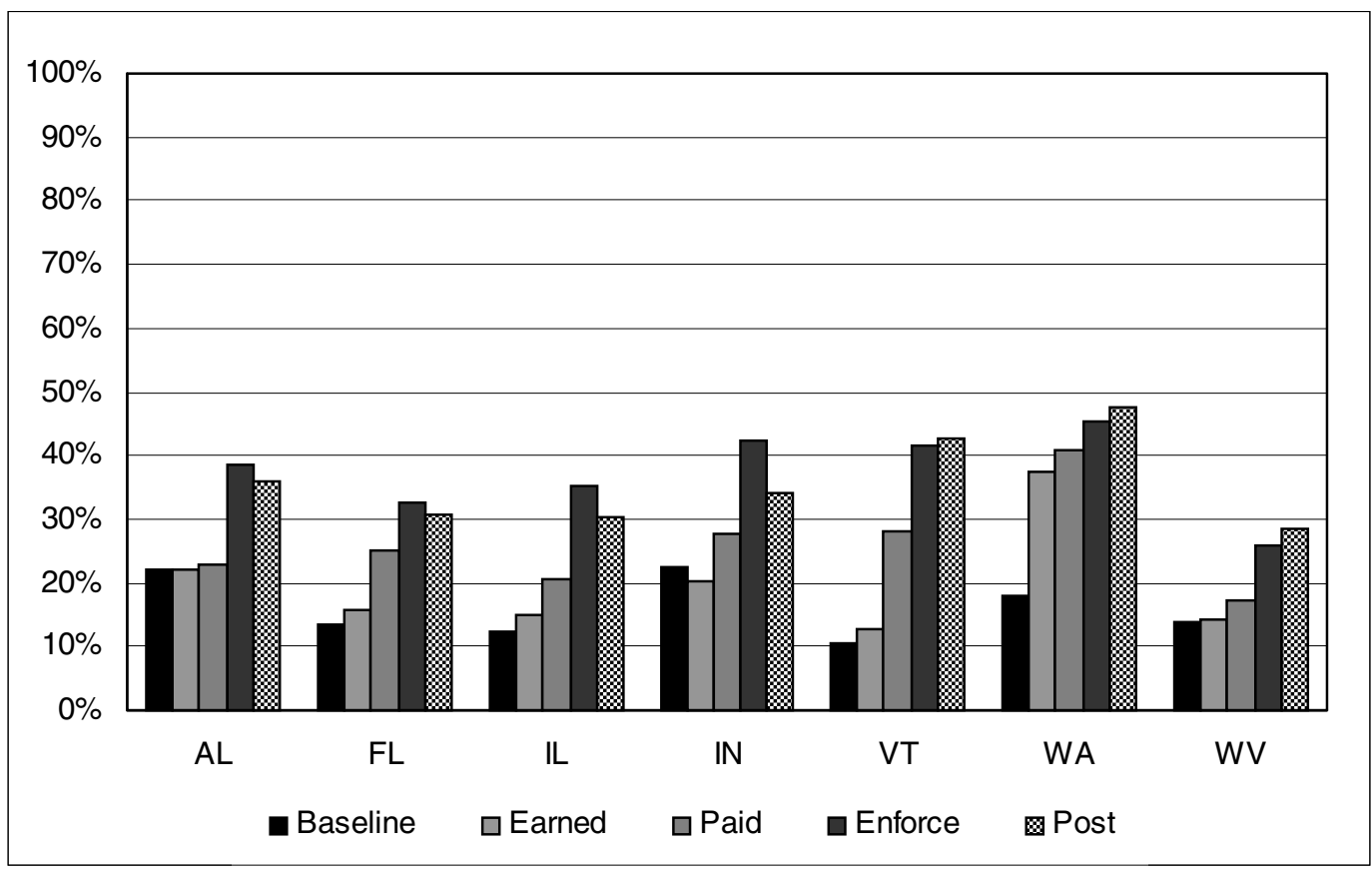

Figure 23. Read about Seat Belts in Newspaper

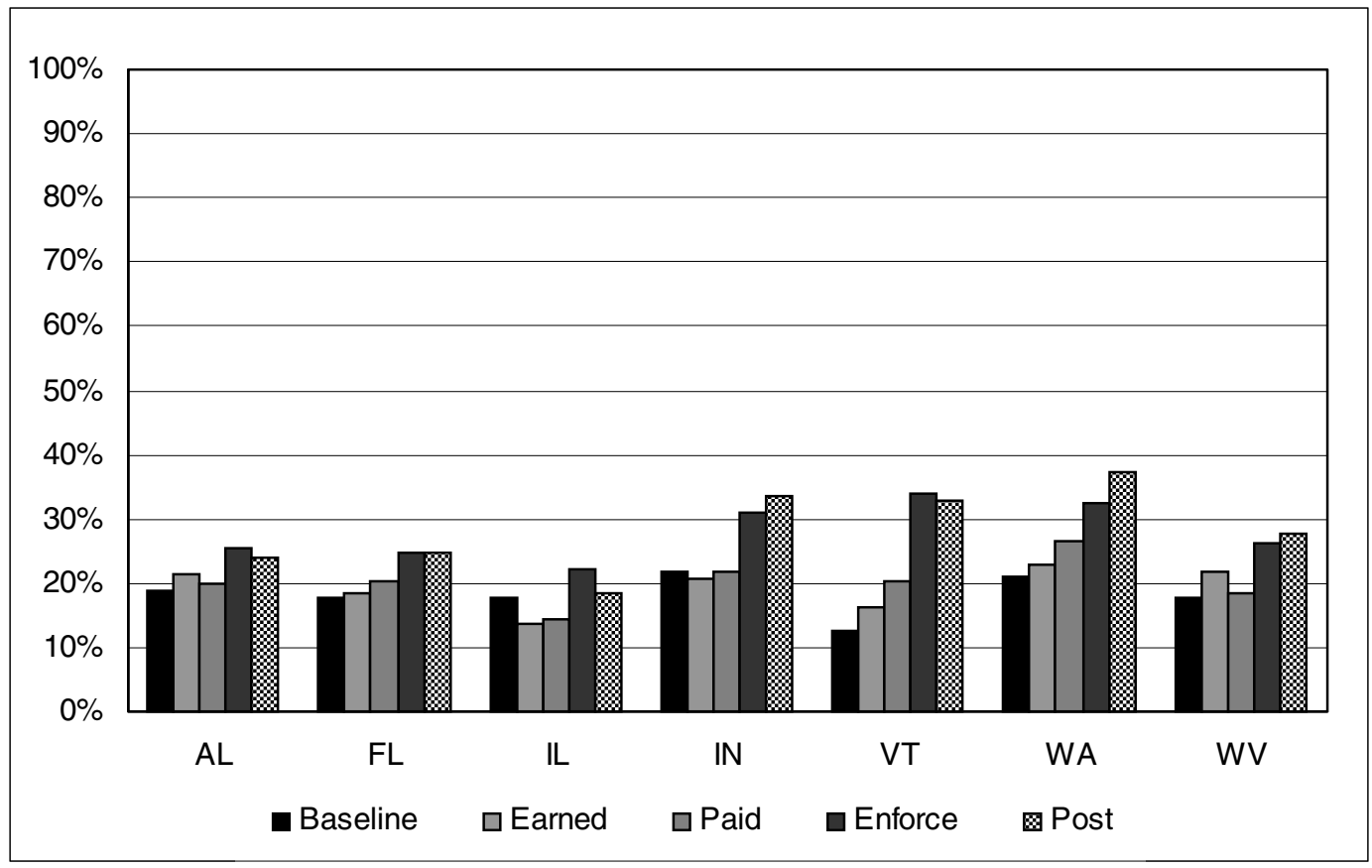


Figure 24. Reports State Police are "Very Strict" in Enforcing the Seat Belt Law

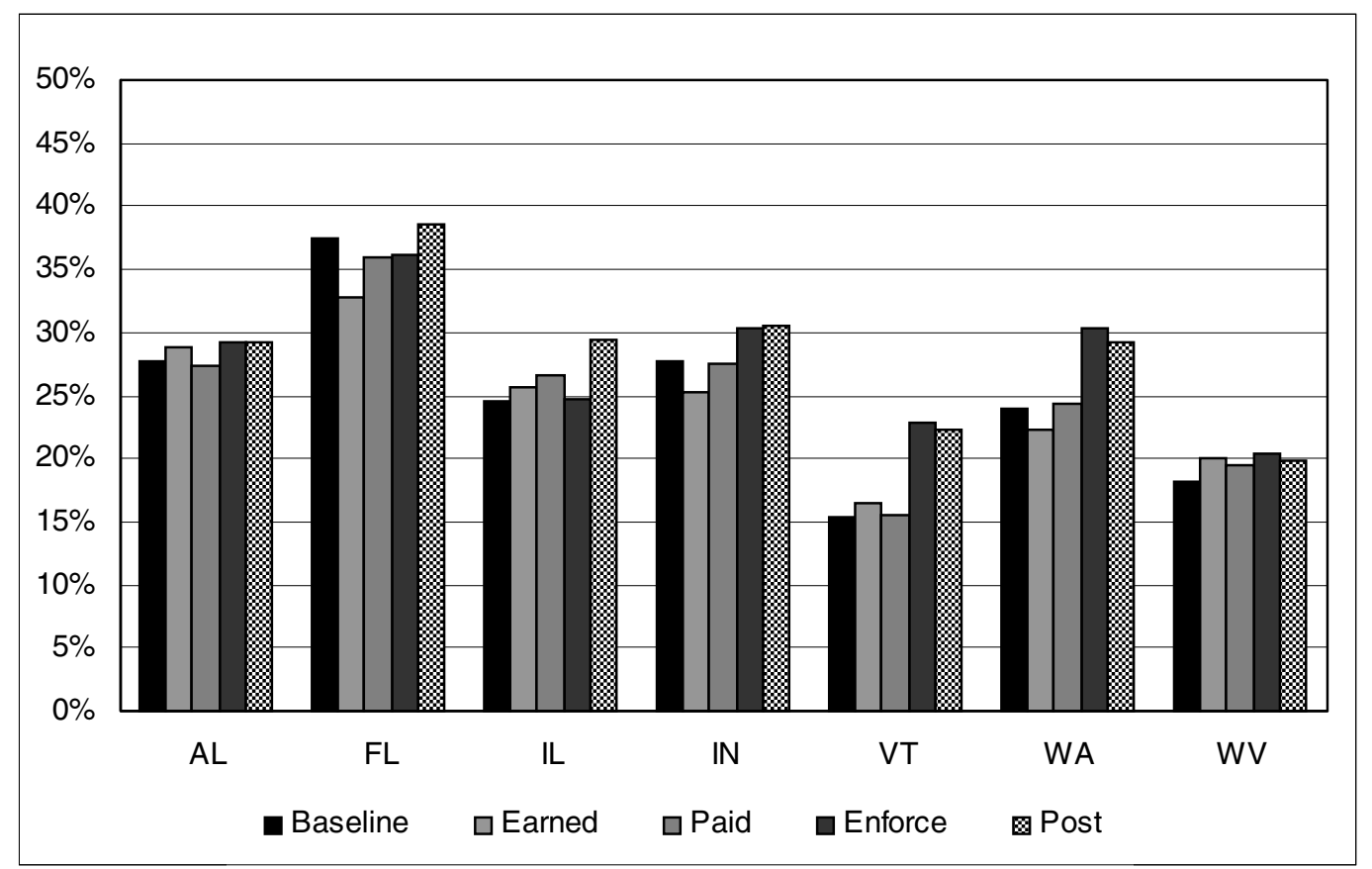

Figure 25. Reports Local Police are "Very Strict" in Enforcing the Seat Belt Law

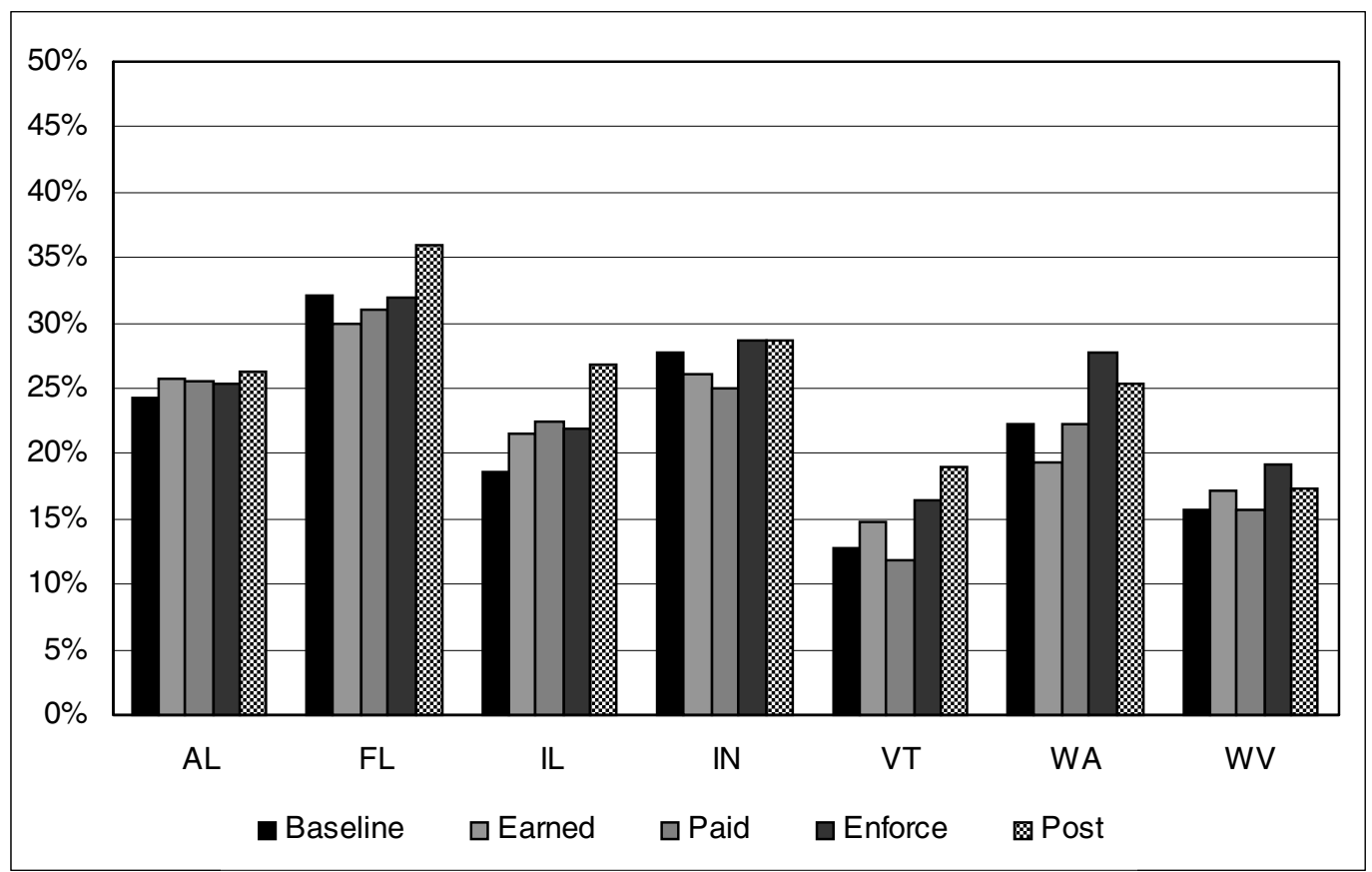


Figure 26. Experienced Enforcement Focused on Seat Belts in Past Month

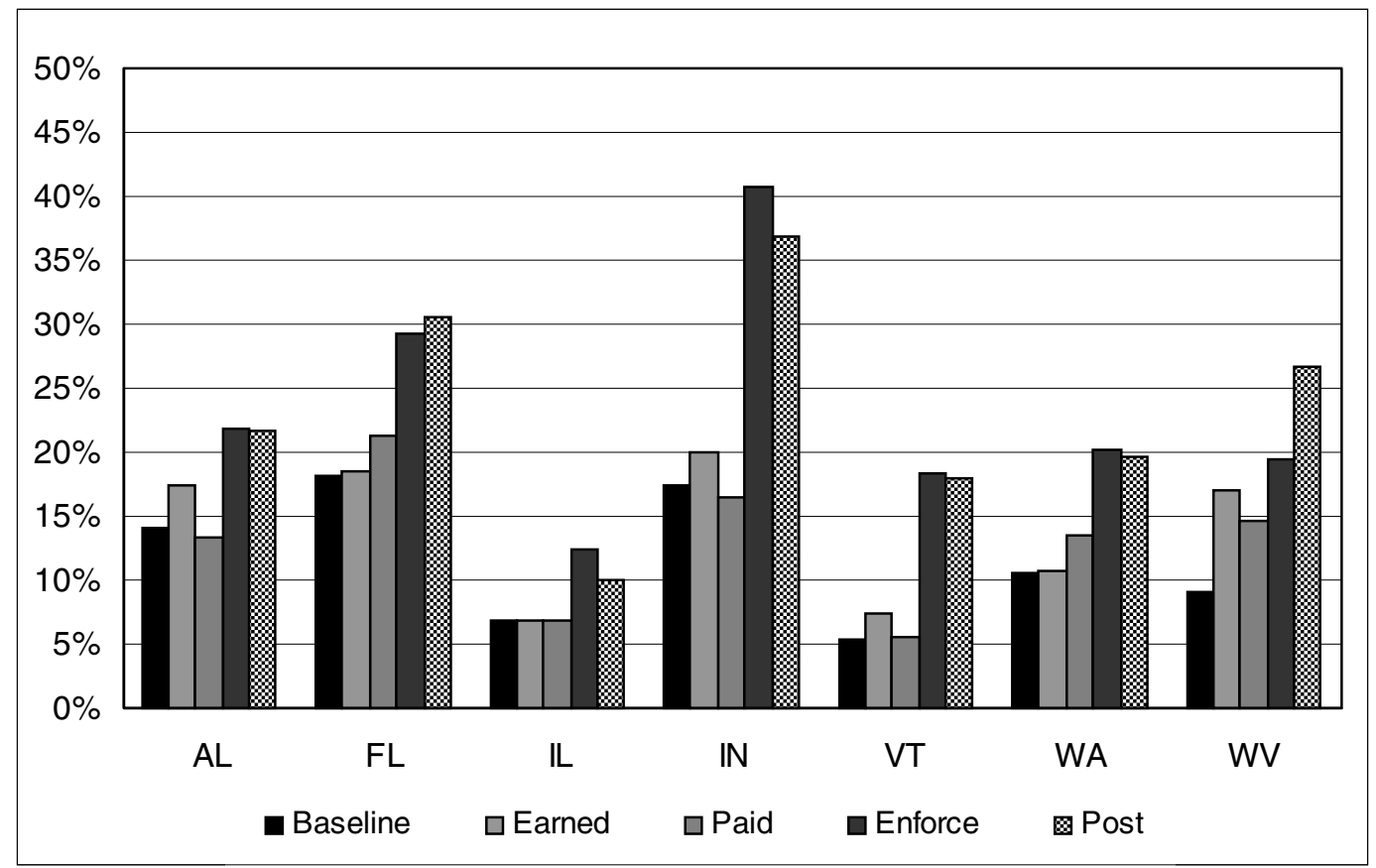

Figure 27. Has Received a Ticket for Not Using a Seat Belt

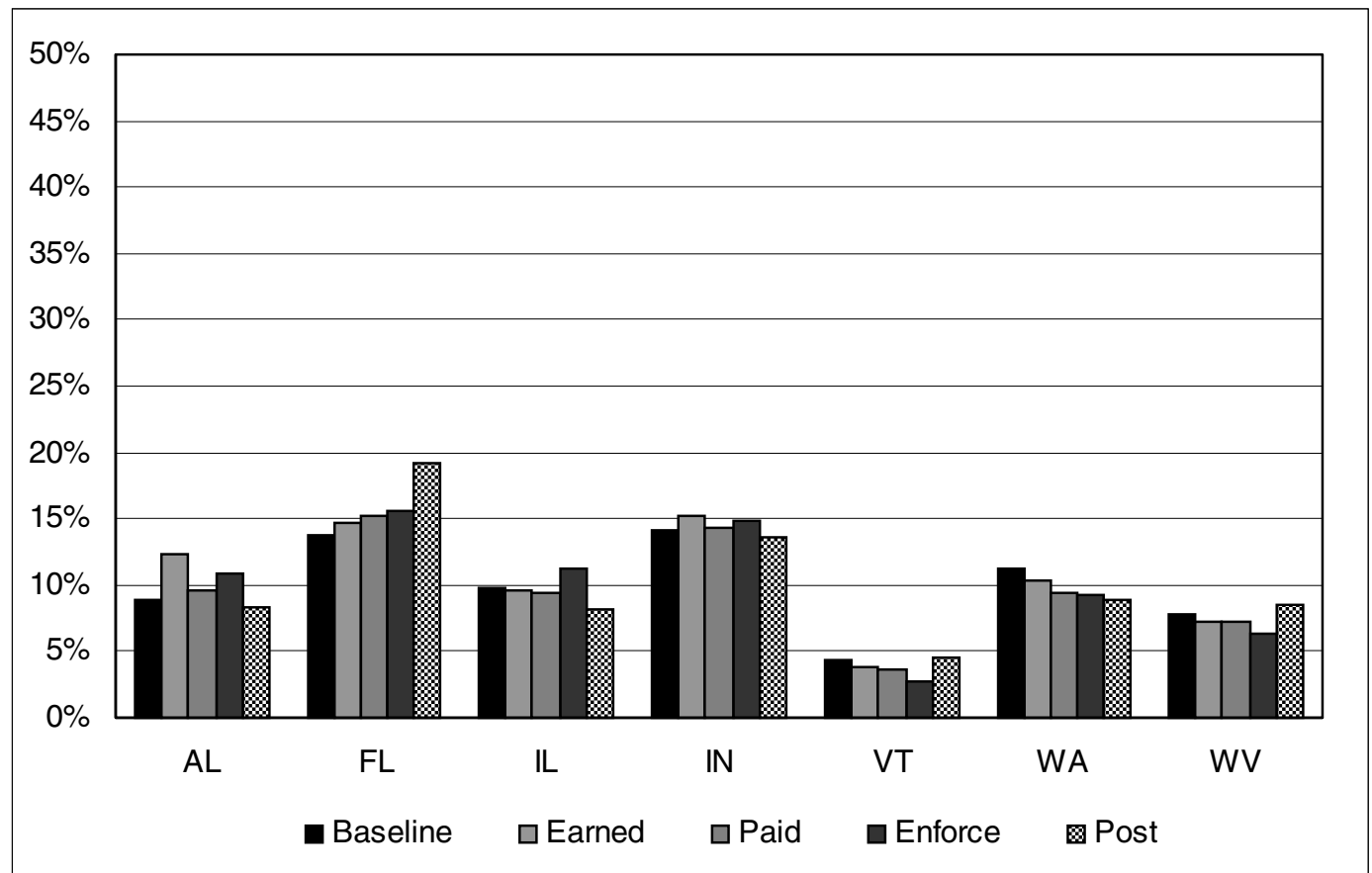


Figure 28. Knows of "Click It or Ticket” Program

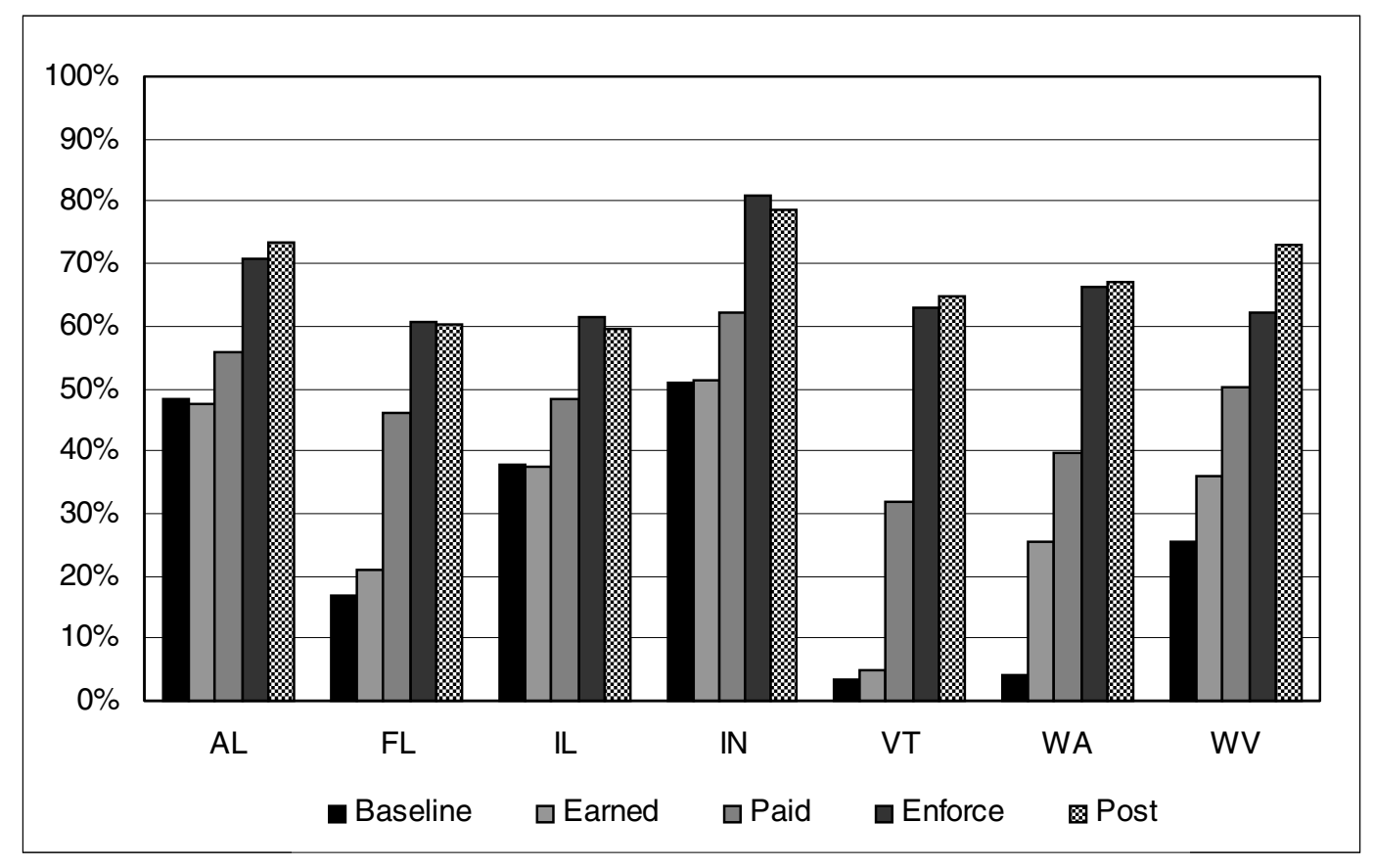




\section{DISCUSSION}

sTEP seat belt enforcement began in this country in Elmira, a small city in New York, during 1985, soon after New York passed the first statewide mandatory seat belt law. Statewide sTEPs were common in the 1990's. One of the earliest, and most successful, was North Carolina's Click It or Ticket program, followed by a similar Click it or Ticket effort in South Carolina. The programs in Elmira, North Carolina and South Carolina were characterized both by intense enforcement and by intense paid media. Similar local and statewide programs, but without paid media, typically failed to achieve the high gains in belt use associated with these highly publicized belt use enforcement efforts.

In May 2001, NHTSA's Region IV coordinated a Click It or Ticket effort across eight southeastern states. Each state in the Region implemented an intense, coordinated, short duration seat belt enforcement program that relied heavily on paid media to reach all motorists. Substantial increases in the belt use rate were seen in every state. The population weighted, region-wide, increase was nine percentage points. It is estimated that hundreds of lives were saved.

The present evaluation covers Click It or Ticket as implemented in states across the country during May 2002. Typically, the period surrounding Memorial Day is devoted to a belt use enforcement mobilization. National publicity announces the mobilization and police agencies from every state participate, and changes in belt use are observed. For most states, the May 2002 mobilization proceeded as it had in years past. However, based on the success in Region IV during May 2001, a number of states went beyond the typical mobilization and implemented a full Click It or Ticket model including an intense paid media campaign. Ten of these states were compared with four states that conducted belt use enforcement but with limited direct paid advertisement placement and four comparison states that conducted enforcement but without direct placement of paid advertisements.

Belt use increased 8.6 percentage points averaged across the ten Click It or Ticket model states; 2.7 points averaged across the limited paid media states; versus 0.5 points averaged across the states not using direct advertisement placement. Among the Full Implementation group, increases occurred in all 10 states, either primary or secondary and with either high or low baselines; belt use increased in three of four states with limited paid media and in two of four comparison states.

The Click it or Ticket timeline begins with a period of "earned" media, followed by at least one week of paid media, followed by enforcement. Substantial increases in belt use were generally not seen during the periods of earned or paid media only. Rather, substantial increases were dependent on both having the paid media and having ongoing heightened enforcement. The combination of paid media and enforcement typically occurs three to four weeks into the program. Survey results indicated, by that time, most knew about the heightened enforcement of seat belt laws and many had personally experienced it.

One of the goals of the current evaluation was to document the level of effort and amount of activity. The results showed that nearly ten million dollars were spent on paid advertising in the ten full implementation Click It or Ticket states plus the four partial implementation states. Approximately 250,000 belt use citations were reported during the enforcement period across all eighteen states; nearly 140,000 in the ten full implementation Click It or Ticket states. Substantial resources were clearly devoted to this effort.

Ostensibly, the role of the current evaluation was to assess program implementation and program results. However, as the May mobilization developed, the evaluation seemed to take on a somewhat larger function. Every state knew that they were part of a national program, their numbers were going to be compared with every other state, and they would be measured at every step in their program implementation. And, measured they were. Tens of thousands of phone interviews and DMV surveys were conducted; nearly 1.2 million front seat occupants were observed. Evaluation became an integral part of the total effort and was 
likely a factor in creating competition among the states with respect to the success of each of their statewide efforts.

In summary, the results of the May 2002 Click It or Ticket program have confirmed that intensive, short term and well publicized enforcement will produce large gains in seat belt use. The results also suggest that enforcement with only modest paid media and intensive enforcement with no paid media will have some effect but not to the extent of the full Click It or Ticket implementation. 


\section{REFERENCES}

Insurance Institute for Highway Safety (1994). Super success in North Carolina (Status Report). Arlington, Virginia.

Jonah, B.A., Dawson, N.E., and Smith, G.A. (1982). Effects of a selective traffic enforcement program on seat belt usage. Journal of Applied Psychology, 67, 89-96.

Solomon, M.G. (2002) Evaluation of NHTSA's Region IV Click It or Ticket Campaign, May 2001 (Final Report). Washington DC: U.S. Department of Transportation; National Highway Traffic Safety Administration, report number DOT HS 809404.

Solomon, M.G., Nissen, W.J., and Preusser, D.F. (1999). Occupant protection special traffic enforcement program evaluation (Final Report). Washington DC: U.S. Department of Transportation; National Highway Traffic Safety Administration, report number DOT HS 808884.

Solomon, M.G. and Preusser, D.F. Evaluation of South Carolina's click it or ticket campaign (Final Report). Washington DC: U.S. Department of Transportation; National Highway Traffic Safety Administration, in process.

Williams, A.F., Wells, J.K., McCartt, A.T., Preusser, D.F. (2000) "Buckle Up NOW!" an enforcement program to achieve high seat belt use. Journal of Safety Research, 31, 195-201.

Williams, A.F., Lund, A.K., Preusser, D.F., Blomberg, R.D. (1987). Results of a set seat belt use law enforcement and publicity campaign in Elmira, New York. Accident Analysis and Prevention, 19, 243249. 


\section{APPENDICES}





\section{PLANNING TIMELINE FOR CLICK IT OR TICKET}

\begin{tabular}{|c|c|}
\hline Weeks 1-4 & $\begin{array}{l}\text { Building Support of Political and Law Enforcement Leadership } \\
\text { - Schedule initial meetings with key political leaders: Governor; Attorney General; Colonel for Highway } \\
\text { Patrol/State Police; Black Caucus; Police Chief's and Sheriff's Associations } \\
\text { - Obtain letters of support from Executive Directors and Presidents of major law enforcement associations; } \\
\text { place campaign announcements in association newsletters } \\
\text { - Create subcommittees, including: 1) Enforcement; 2) Diversity Outreach; 3) Media/PI\&E; 4) Evaluation } \\
\text { - Send Governor's letter to all law enforcement agencies, political leaders, judiciary and minority leaders } \\
\text { - Develop Click It or Ticket brochure with state logo } \\
\text { - Develop and contract for publicity and education materials }\end{array}$ \\
\hline Weeks 5-6 & $\begin{array}{l}\text { Obtain Law Enforcement Agency Commitments and Host First Statewide Click It or Ticket Meeting } \\
\text { - } \quad \text { Law enforcement liaisons (LEL) begin visits in field to garner local law enforcement agency support } \\
\text { - } \text { Outreach, Media and Evaluation) } \\
\text { - Conduct Region-wide LEL Conference with focus on Click It or Ticket } \\
\text { Prepare for Diversity Outreach } \\
\text { - Identification of key minority spokespersons } \\
\text { - Obtain mailing addresses for minority weekly newspapers } \\
\text { - Compile crash data and fact sheets for dissemination } \\
\text { - Conduct pre-meetings with key minority organizations (e.g. NAACP, Black Caucus, La Roze, COSMOS) } \\
\text { - Coordinate with minority organizations to send newsletters to constituents about the need for the campaign } \\
\text { Work with media firm to Produce TV and Radio Ads } \\
\text { - Select appropriate law enforcement personnel for the ads } \\
\text { Evaluation Subcommittee Leadership Attends Training Session on Click It or Ticket Evaluation Methods }\end{array}$ \\
\hline Weeks 7-8 & $\begin{array}{l}\text { Develop Media Strategy } \\
\text { - Media Subcommittee outlines plans for earned media and begins to schedule events } \\
\text { - Media planners identify special markets for targeted paid ads; reviews paid ad buy plan developed by the paid } \\
\text { - } \text { Establish Click It or Ticket checkpoint locations } \\
\text { - Continue to work with media firm to produce radio and TV ads } \\
\text { Finalize the Enforcement Plan \& Host Statewide Click It or Ticket Committee Meeting } \\
\text { - Establish checkpoint locations and plan for enforcement data collection } \\
\text { - Host statewide Click It or Ticket Committee Meeting - subcommittees develop action plans }\end{array}$ \\
\hline Weeks 9-13 & $\begin{array}{l}\text { Structure Evaluation Plan } \\
\text { Conduct Law Enforcement Briefings } \\
\text { - Conduct statewide law enforcement briefing and kick off } \\
\text { - Hold regional law enforcement briefings in Highway Patrol/State Police Districts } \\
\text { - Host statewide Click It or Ticket committee and subcommittee meetings } \\
\text { Finish filming and producing the radio and television ads }\end{array}$ \\
\hline
\end{tabular}




\section{PROGRAM TIMELINE FOR CLICK IT OR TICKET}

\begin{tabular}{|c|c|}
\hline Weeks 11-13 & $\begin{array}{l}\text { Conduct Baseline Data Collection } \\
\text { - Conduct statewide belt use survey } \\
\text { - Conduct Driver Licensing Office survey } \\
\text { - Conduct resident telephone survey }\end{array}$ \\
\hline Week 14 & $\begin{array}{l}\text { Begin Earned Media Phase } \\
\text { - Governor's announcement of Media Campaign (media event) } \\
\text { Conduct Mini Observational Belt Use Survey and Driver Licensing Office Survey (towards end of week) }\end{array}$ \\
\hline Weeks 15-16 & $\begin{array}{l}\text { Begin Paid Media Phase } \\
\text { - Air radio and television paid ads } \\
\text { Conduct Mini Observational Belt Use Survey and Driver Licensing Office Survey (towards end of week) }\end{array}$ \\
\hline Weeks 16-17 & $\begin{array}{l}\text { Continue Paid Media Phase } \\
\text { Begin Enforcement Phase } \\
\text { - Conduct statewide Kick-Off Event for Strict Enforcement } \\
\text { - Begin two-weeks of enforcement } \\
\text { - Conclude radio and television paid ads } \\
\text { Conduct Mini Observational Belt Use Survey and Driver Licensing Office Survey (end of second week) }\end{array}$ \\
\hline Week 18 & $\begin{array}{l}\text { Conduct Post Campaign Data Collection } \\
\text { - Conduct statewide belt use survey } \\
\text { - Conduct Driver Licensing Office survey } \\
\text { - Conduct resident telephone survey } \\
\text { Disseminate preliminary campaign results }\end{array}$ \\
\hline Weeks 19-21 & $\begin{array}{l}\text { Post Campaign Media Briefing and Appreciation Event } \\
\text { Disseminate final campaign results }\end{array}$ \\
\hline
\end{tabular}


SAMPLE - SEAT BELT SURVEY - DATA COLLECTION FORM

Site number:

State:

County:

Date:

Day of week:

Start Time:

\begin{tabular}{|c|c|c|c|c|c|c|c|}
\hline & \multicolumn{4}{|c|}{ Driver } & \multicolumn{3}{|c|}{ Front Outboard Passenger } \\
\hline & $\begin{array}{l}\text { VEHICLE TYPE } \\
\text { C-Pass Car } \\
\text { T-Pick Up } \\
\text { S-SUV } \\
\text { V-Van }\end{array}$ & $\begin{array}{l}\text { RACE } \\
\text { W-White } \\
\text { B-Black } \\
\text { U-Unknown }\end{array}$ & $\begin{array}{l}\text { SEX } \\
\text { M-Male } \\
\text { F-Female } \\
\text { U-Unknown }\end{array}$ & $\begin{array}{l}\text { SEAT BELTED } \\
\text { Y-Yes } \\
\text { N-No }\end{array}$ & $\begin{array}{l}\text { RACE } \\
\text { W-White } \\
\text { B-Black } \\
\text { U-Unknown }\end{array}$ & $\begin{array}{l}\text { SEX } \\
\text { M-Male } \\
\text { F-Female } \\
\text { U-Unknown }\end{array}$ & $\begin{array}{l}\text { SEAT BELTED } \\
\text { Y-Yes } \\
\text { N-No }\end{array}$ \\
\hline 1 & & & & & & & \\
\hline 2 & & & & & & & \\
\hline 3 & & & & & & & \\
\hline 4 & & & & & & & \\
\hline 5 & & & & & & & \\
\hline 6 & & & & & & & \\
\hline 7 & & & & & & & \\
\hline 8 & & & & & & & \\
\hline 9 & & & & & & & \\
\hline 10 & & & & & & & \\
\hline 11 & & & & & & & \\
\hline 12 & & & & & & & \\
\hline 13 & & & & & & & \\
\hline 14 & & & & & & & \\
\hline 15 & & & & & & & \\
\hline 16 & & & & & & & \\
\hline 17 & & & & & & & \\
\hline 18 & & & & & & & \\
\hline 19 & & & & & & & \\
\hline 20 & & & & & & & \\
\hline 21 & & & & & & & \\
\hline 22 & & & & & & & \\
\hline 23 & & & & & & & \\
\hline 24 & & & & & & & \\
\hline 25 & & & & & & & \\
\hline
\end{tabular}





\section{SAMPLE - ENFORCEMENT ACTIVITY REPORT FORM}

Host Agency:

Contact Person:

Phone:

\section{Enforcement Information}

Type of Enforcement:

(e.g., Checkpoint, Saturation, Other)

Date of Activity: Start Time:

End Time:

Location:

Participating Agencies:

Number of Officers/Officer Hours

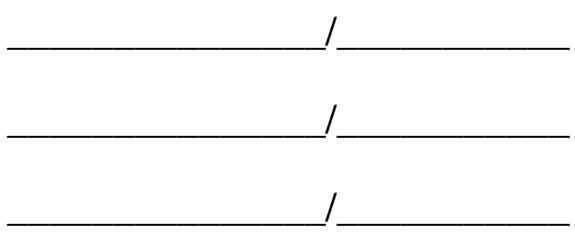

\begin{tabular}{|l|l|l|}
\hline Violations & Number of Tickets & Number of Arrests \\
\hline Seat Belt & & \\
\hline Child Restraint & & \\
\hline Speed & & \\
\hline Other Moving Violations & & \\
\hline Non-Moving Violations & & \\
\hline DWI/DUI & & \\
\hline Non-Traffic Misdemeanor & & \\
\hline Non-Traffic Felony & & \\
\hline
\end{tabular}

Please describe significant incidents, including any non-traffic arrests, resulting from enforcement efforts: 



\section{SAMPLE - DRIVER LICENSING OFFICE SURVEY}

This driver licensing office is assisting in a study about seat belts in North Carolina. Your answers to the following questions are voluntary and anonymous. Please complete the survey and then put it in the drop box.

1. Your sex: $\square$ Male $\quad \square$ Female

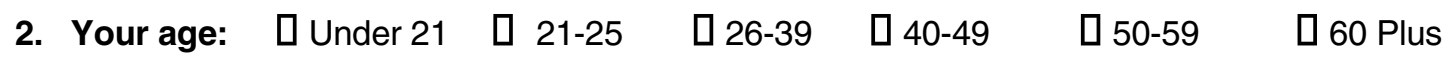

3. Your race: $\square$ White $\square$ Black $\square$ Asian $\square$ Native American $\quad \square$ Other

4. Are you of Spanish/Hispanic origin? $\quad$ Yes $\quad$ No

5. Your Zip Code:

6. About how many miles did you drive last year?

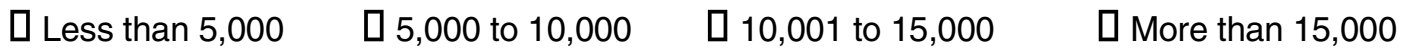

7. What type of vehicle do you drive most often?

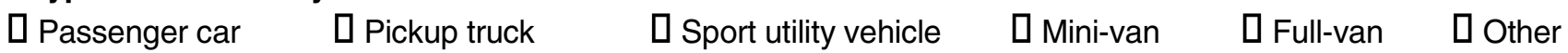

8. How often do you use seat belts when you drive or ride in a car, van, sport utility vehicle or pick up?
CAlways
$\square$ Nearly always
$\square$ Sometimes
$\square$ Seldom
$\square$ Never

9. What do you think the chances are of getting a ticket if you don't wear your seat belt?
Always
$\square$ Nearly Always
Cometimes
$\square$ Seldom
C Never

10. Do you think the North Carolina Highway Patrol enforce the seat belt law:
Q Very strictly
$\square$ Somewhat strictly
$\square$ Not very strictly
Q Rarely
$\square$ Not at all

11. Do you think local police enforce the seat belt law:
$\square$ Very strictly
$\checkmark$ Somewhat strictly
Not very strictly
Rarely
Not at all

12. Have you ever received a ticket for not wearing your seat belt?

$\square$ Yes $\square$ No

13. In the past month, have you seen or heard about a checkpoint where police were looking at seat belt use?
$\square$ Yes
$\square$ No

14. In the past month, have you gone through a checkpoint where police were looking at seat belt use?
$\square$ Yes
$\square$ No

15. Have you recently read, seen or heard anything about seat belts in North Carolina?

$\checkmark$ Yes $\quad \mathrm{N}$ No

If yes, where did you see or hear about it? (Check all that apply):

$\square$ Newspaper $\square$ Radio $\square$ TV $\square$ Poster $\square$ Brochure $\square$ Police checkpoint $\square$ Other

If yes, what did it say?

16. Do you know the name of any seat belt enforcement program(s) in North Carolina? (check all that apply):
$\square$ No Excuses, Buckle Up
$\checkmark$ Buckle Up North Carolina
Click It or Ticket
$\square$ Operation Stay Alive 


\section{SAMPLE - DRIVER LICENSING OFFICE SURVEY}

DMV está ayudando en un estudio sobre cinturones de seguridad en Carolina del Norte. Sus respuestas a las siguientes preguntas son voluntarias y anónimas. Porfavor completar este formulario y coloquelo en la caja indicada.

1. Su sexo: $\square$ Masculino $\square$ Femenino

2. Su edad: $\square$ Menor de 21 años $\quad \square 21-25 \quad \square 26-39 \quad \square 40-49 \quad \square 50-59 \quad \square 60+$

3. Su Raza: $\square$ Blanco $\square$ Negro $\square$ Asiático $\square$ Indígena (US) $\quad$ Otro

4. ¿Es usted de origen Espa ol/Hispano?

5. Su codigo postal (Zip):

6. ¿Aproximadamente cuántas millas manejo usted el $\mathrm{a}^{\bullet}$ o pasado?
$\square$ Menos de 5,000
$\square, 000$ a 10,000
10,001 a 15,000
$\square$ Más de 15,000

7. ¿Que tipo de automovil maneja usted frecuentemente?

$\square$ Automobil de pasajeros $\square$ Camioneta(pickup) $\square$ Automobil de recreo(SUV) $\square$ Mini-vagoneta(van) $\square$ vagoneta(van) $\square$ Otro

8. ¿Que tan frecuentemente usa usted el cinturón de seguridad cuando maneja ó es pasajero dentro de un coche, vagoneta automovil de recreo ó camioneta?
C Siempre
Casi siempre
Algunas veces
Rara vez
ONunca

9. ¿Qué cree que son las probabilidades de que le den una multa por no usar el cinturón de seguridad?
\ Siempre
Casi siempre
$\square$ Algunas veces
Rara vez
O Nunca

10. ¿Cree usted que la Patrulla de Carreteras de Carolina del Norte exije que la ley del cinturón de seguridad se cumpla?
$\checkmark$ Muy estrictamente
$\checkmark$ Un poco estrictamente
$\checkmark$ No muy estrictamente
Rara vez $\square$ Nunca

11. ¿Cree usted que la policia local exije que la ley del cinturón de seguridad se cumpla ?

$\checkmark$ Muy estrictamente $\quad \square$ Un poco estrictamente $\quad \square$ No muy estrictamente $\quad \square$ Rara vez $\quad$ Nunca

12. ¿Ha recibido usted alguna vez una multa por no usar su cinturón de seguridad?

$\mathrm{CSi} \quad \mathrm{No}$

13. ¿En el mes pasado ha usted visto ó oido sobre un punto de inspección donde la policia estaba chequeando el uso de cinturones de seguridad?

$\mathrm{CSi} \quad \mathrm{N}$ No

14. ¿En el mes anterior ha usted pasado atravez de un punto de inspección donde la policia estaba chequeando el uso de cinturones de seguridad?

$\mathrm{Si} \quad \mathrm{N}$ No

15. ¿Ha leído, visto ó oído usted recientemente algo sobre cinturones de seguridad en Carolina del Norte?

$\mathrm{CS} \quad \mathrm{N}$ No

Si contesto sí, ¿Donde lo vió ó oyó? (Marque todas las casillas que correspondan)

$\square$ Periodico $\square$ Radio $\square$ Television $\square$ Carteles $\square$ folleto $\square$ punto de Inspección Policial $\square$ Otro

Si contesto si, ¿Qué decía?

16. ¿Conoce usted el nombre de algun programa(s) de la ley de cinturones de seguridad en Carolina del Norte?

$\square$ No hay excusas, Abrochese $\square$ Abrochese Carolina del Norte $\square$ Abrochese ó multa $\square$ Operación Abrochate y Mantente Vivo 
Click It or Ticket:

Statewide Telephone Surveys:

May and June 2002

\section{BANNERS}

\section{Conducted by}

Schulman, Ronca and Bucuvalas, Inc. 


\section{CLICK IT OR TICKET: STATEWIDE TELEPHONE SURVEYS MAY/JUNE 2002 SEAT BELT TRACKING STUDY}

Q.1 How often do you drive a motor vehicle? Almost every day, a few days a week, a few days a month, a few days a year, or do you never drive?

Q.2 Is the vehicle you drive most often a car, van, motorcycle, sport utility vehicle, pickup truck, or other type of truck?

Q.3 Do the seat belts in the front seat of the (car/truck/van) go across your shoulder only, across your lap only, or across both your shoulder and lap?

Q.4 When driving this (car/truck/van), how often do you wear your shoulder belt?

Q.5 When driving this (car/truck/van), how often do you wear your lap belt?

Q.6 When was the last time you did NOT wear your seat belt when driving?

Q.7 In the past 30 days, has your use of seat belts when driving (vehicle driven most often) increased, decreased, or stayed the same?

Q.8 What caused your use of seat belts to increase?

Q.9 Does (respondent's state) have a law requiring seat belt use by adults?

Q.10 Assume that you do not use your seat belt AT ALL while driving over the next six months. How likely do you think you will be to receive a ticket for not wearing a seat belt?

Q.11 According to your state law, can police stop a vehicle if they observe a seat belt violation or do they have to observe some other offense first in order to stop the vehicle?

Q.12 In your opinion, should police be allowed to stop a vehicle if they observe a seat belt violation when no other traffic laws are being broken?

Q.13 Please tell me whether you strongly agree, somewhat agree, somewhat disagree or strongly disagree with the following statements?

a) Seat belts are just as likely to harm you as help you.

b) If I was in an accident, I would want to have my seat belt on.

c) Police in my community generally will not bother to write tickets for seat belt violations.

d) It is important for police to enforce the seat belt laws.

e) Putting on a seat belt makes me worry more about being in an accident.

f) Police in my community are writing more seat belt tickets now than they were a few months ago.

Q.14 Yes or No--in the past 30 days, have you seen or heard of any special effort by police to ticket drivers in your community for seat belt violations?

Q.15 Where did you see or hear about that special effort?

Q.16 Was the (tv/radio) message a commercial (or advertisement), was it part of a news program, or was it something else?

If state EQ Indiana or Michigan Skip to alternative Q17,

All Other States Except Ohio skip to Q24.

Q17 Yes or no- in the past 30 days, have you seen or heard anything about the police setting up seat belt checkpoints where they will stop motor vehicles to check whether drivers and passengers are wearing seat belts?

Q.18 Let me just confirm, is this the type of checkpoint that you have seen or heard about in the past 30 days? 


\section{CLICK IT OR TICKET: STATEWIDE TELEPHONE SURVEYS MAY/JUNE 2002 SEAT BELT TRACKING STUDY}

Q.19 Where did you see or hear about the police checkpoints for seat belts?

Q.20 Was the (tv/radio) message a commercial (or advertisement), was it part of a news program, or was it something else?

Q.21 In the past 30 days, did you personally see any checkpoints where police were stopping motor vehicles to see if drivers and passengers were wearing seat belts?

Q.22 Let me just confirm, is this the type of checkpoint that you personally saw in the past 30 days?

Q.23 Were you personally stopped by police at a seat belt checkpoint in the past 30 days?

Q.24 In the past 30 days, have you seen or heard of any special effort by police to ticket drivers in your community if children in their vehicles are not wearing seat belts or are not in car seats?

Q25 Now, I would like to ask you a few questions about educational or other types of activities? In the past 30 days, have you seen or heard any messages that encourage people to wear their seat belts. This could be public service announcements on TV, messages on the radio, signs on the road, news stories, or something else.

Q.26 Where did you see or hear these messages?

Q 27 Was the (tv/radio) message a commercial (or advertisement), was it part of a news program, or was it something else?

Q.28 Would you say that the number of these messages you have seen or heard in the past 30 days is more than usual, fewer than usual, or about the same as usual?

Q.29 Are there any advertisements or activities that you have seen or heard in the past $\mathbf{3 0}$ days that encouraged adults to make sure that children use car seats or seat belts?

Q31 Thinking about everything you have heard, how important do you think it is for [respondent's state] to enforce seat belt laws for ADULTS more strictly . . . . very important, fairly important, just somewhat important, or not that important?

Q32 Do you recall hearing or seeing slogans in the past 30 days?

Q.33 Now, I need to ask you some basic information about you and your household. What is your age?

Q.34 Including yourself, how many persons, age 16 or older, are living in your household at least half of the time or consider it their primary residence?

Q35 How many children age 15 or younger are living in your household at least half of the time or consider it their primary residence?

Q.36 Do you consider yourself to be Hispanic or Latino?

Q.37 Which racial categories describe you?

Q.38 What is the highest grade or year of school you completed?

Q.39 Do you have more than one telephone number in your household?

Q.40 Not including cells phones, and numbers used primarily for fax or computer lines, How many different telephone numbers do you have in your household? 